\title{
金属イオン $\{\mathbf{M}\}$-有機試薬 $\{\mathbf{R}\}$ 反応を用いる光分析法
}

\author{
森逸男 \\ 大阪薬科大学第 II 分析化学教室, $=$ T 569-1094 高槻市奈佐原 4-20-1
}

\section{Photometric Analysis with Reaction between \\ Metal Ion $\{\mathbf{M}\}$ and Organic Reagent $\{\mathbf{R}\}$}

\author{
Itsuo MORI \\ Laboratory of Analytical Chemistry II, Osaka University of Pharmaceutical Sciences, \\ 4-20-1 Nasahara, Takatsuki 569-1094, Japan
}

(Received May 2, 2001)

\begin{abstract}
Firstly, the syntheses of various organic reagents $\{R\}$ containing such xanthene derivatives as O-hydroxyhydroquinonephthalein $(\mathrm{QnPh})$, and 3,4,5,6-tetrahydroxyfluoran (gallein, Gall) were studied. Secondarily, the coexisting effects of surfactant (cationic-, anionic-, amphoteric- and nonionic-surfactants alone or combination) on the coloring or fluorescence reactions between various $\{R\}$ such as xanthene derivatives, aromatic amines and various metal ions $\{\mathrm{M}\}$ such as bismuth (III), tin (IV), iron (III), molybdenum (VI), uranium (VI), cobalt (II), aluminum (III), etc. were systematically investigated. Thirdly, numerous simple and sensitive photometric analyses (spectrophotometry and fluorophotometry) for various $\{\mathrm{M}\}$ and organic compounds $\{\mathrm{Org}\}$ such as biological samples, and pharmaceutical preparations by formation reactions of $\{\mathrm{R}-\mathrm{M}\}$ binary or $\{(\mathrm{R}-\mathrm{M})-\mathrm{Org}\}$ ternary complexes were established in the coexistence of surfactant alone or combination.
\end{abstract}

Key words_ organic reagents; metal ion; surfactants; associated complexes; photometric analysis; pharmaceuticals and biologicals

\section{はじめに}

紫外・可視吸光分析法は, 簡便, 迅速, 再現性に 優れた方法として無機金属あるいは非金属イオン $\{\mathrm{M}\}$, さらには医薬品, 生体関連物質などの有機物 質 $\{\mathrm{Org}\}$ の分析に汎用されるなど, 光分析法の応 用範囲は極めて広い. 従来, 分析化学面で利用され る有機試薬 $\{\mathrm{R}\}$ は, 分子構造の中に $\mathrm{N}, \mathrm{O}, \mathrm{S}$ など の原子を 2 つ以上有し，金属イオン $\{\mathrm{M}\}$ と五ある いは六員環構造の “カニのはさみ” 類似の環を形成 するキレート試薬が大半である。ほとんどの $\{\mathrm{M}\}$ は，N-O あるいは O-O 配位型で， N-N 配位はアン ミン錯体を生成する遷移 $\{\mathbf{M}\}$ など，硫化物生成の $\{\mathrm{M}\}$ は，S-S 配位型の金属キレートを生成するが, 錯体の安定性はキレート環の大きさ, 数, 配位原子 の塩基性, 立体効果などによって定まる. なお, 吸 光光度分析に用いられる有機化合物の感度, モル吸 光係数 $(\varepsilon)$ は光吸収の有効断面積と遷移確率の積 に比例し, その值が $10^{5}$ 台であれば, 高感度発色試
薬とされている。近年, (1)電子工学, コンピュー ターの発展による再現性ある高感度な分析機器の供 給, (2)微分分光法あるいは二波長分光法の開発, (3) 高次錯体生成反応の利用拡大, (4)高感度, 高選択的 な有機試薬の開発研究などが行われてきている. と りわけ， $\{\mathbf{R}\}$ と $\{\mathbf{M}\}$ 間の錯形成反応への長鎖ア ルキル基含有水溶性第 4 級アンモ二ウム塩（陽イオ ン性界面活性剂）の共存効果, 従来の 0- 次微分法 に代る高次微分法の採用, あるいは溶媒抽出法に代 るメンブランフィルター (MF) 前予備濃縮法の採 用などによる高感度, 選択的で簡便な光分析法が検 討されてきている.さらに, 高速液体クロマトグラ フイー(HPLC), 流れ分析 (FIA) 法, 高次微分分 光法, サーマルレンズ法などにおける検出手段に, 光分析法が汎用されるなど, その重要性が大いに注 目視されている.これら現況を踏まえ, 著者らは光 分析法改良を目的に, (1)キサンテン系試薬, とりわ けフタレイン系試薬並びに芳香族アミン系試薬 $\{\mathrm{R}\}$

本総説は, 平成 12 年度退官にあたり在職中の業績を中心に記述されたものである. 
を新たに合成した。 ついで，これら $\{\mathbf{R}\}$ と $\{\mathbf{M}\}$ 間の吸光並びに蛍光反応を各種界面活性剂（陽, 陰, 非, 両イオン性）併用下に検索し, 金属含有物 質…合金，食料品，医薬品，生活廃水，工場排水， 雨水など…中の各種金属, 非金属イオンの高感度, 簡便な定量法の開発研究，(2)従来の $\{\mathrm{M}\}$ あるいは $\{\mathrm{R}\}$ 単独を用いる医薬品, 生体関連物質 $\{\mathrm{Org}\}$ な どの定量法に代えて, 各種界面活性剂併用下, $\{(\mathrm{R}-\mathrm{M})-\mathrm{Org}\}$ 間に得られる反応体を活用した水相 内での簡便, 迅速, 高感度で選択的な新規 $\{\mathrm{Org}\}$ 定量法の開発を検討した。 以下，(1)有機試薬 $\{R\}-$ 金属イオン $\{\mathbf{M}\}$ 間の反応及び(2)有機試薬 $\{\mathbf{R}\}$-金属 イオン $\{\mathrm{M}\}$ 錯体と医薬品, 生体成分 $\{\mathrm{Org}\}$ 間の反 応に分け概説する.

\section{有機試薬 $\{\mathbf{R}\}$-金属イオン $\{\mathbf{M}\}$ 間の反応}

キサンテン環に水酸基（OH）4 個を有する 2,3,7トリヒドロキシ -9- フェニル -6- フルオロン（フェ ニルフルオロン, $\mathrm{Phfl}$ ), カテコールスルホフタレ イン体のピロカテコールバイオレット $(\mathrm{PV})$, ピロ ガロールレッド (PR), ブロモピロガロールレッド （BPR）など, 既に多価金属イオン $\{\mathrm{M}\}$ の金属指 示薬あるいは発色試薬などとして利用されてきてい る. 発色試薬 $\{\mathrm{R}\}$ 開発に際し, O-O 配位型のヒド ロキシフルオラン系（キサンテン系誘導体）試薬及 びN-O 配位型のアゾ系試薬を多数合成し, 各種金 属イオン $\{\mathrm{M}\}$ との反応性を追跡した.

\section{1. 試薬の合成}

1-1. ヒドロキシフルオラン誘導体フルオラ ン環の 1,3,6,8-, 2,4,6,7- あるいは 3,4,5,6- 位のいず れかに $\mathrm{OH}$ 基を有する対称型テトラ - ヒドロキシ 体, ジ - ヒドロキシ体並びに非対称型トリ - ヒドロ キシ体，モノ - ヒドロキシ体などの $\{\mathrm{R}\}$ について, 有機試薬としての有用性を $\mathrm{OH}$ 基の位置と数との 関連，並びにこれら $\{\mathrm{R}\}$ と各種 $\{\mathrm{M}\}$ との反応性 を蛍光及び吸光の両面より追跡した（Fig. 1).

1-1-1. 対称型ヒドロキシフルオラン体：無水フ タール酸と多価フェノールより，3,4,5,6- テトラヒ ドロキシフルオラン（ピロガロールフタレイン, ガ レイン, Gall) , 2,3,6,7- テトラヒドロキシフルオラ ン（O-ヒドロキシヒドロキノンフタレイン, $\mathrm{QnPh}), 1,3,6,8-$ テトラヒドロキシ体（フロログル シンフタレイン) を合成した. カルボキシル基を有 しないフルオロン誘導体は, ベンッアルデヒドと多

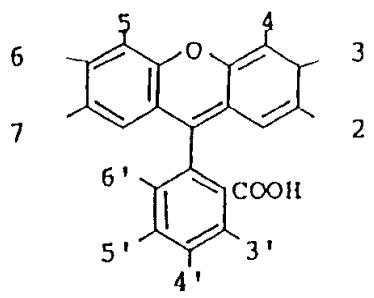

Fig. 1. Chemical Structure of Fluoran

価フェノールの縮合反応により，それぞれピロガ ロールフルオロン (Pyfl), Phfl を, また O-スルホ 安息香酸無水物あるいは P-カルボキシ無水フター ル酸と O-ヒドロキシヒドロキノンより, O-スルホ フェニルフルオロン (Sul.Phfl), P-カルボキシフェ ニルフルオロン (COOH.Phfl) を, さらに Gall, QnPh, Sul.Phfl の 3',4',5',6'- 位，2,7- 位あるいは 4,5- 位に塩素 $(\mathrm{Cl})$ あるいは臭素 $(\mathrm{Br})$ 原子を導入し たテトラ -Cl.Sul.Phfl（T.Cl.Sul.Phfl）, テトラ X.Gall (T.Cl.Gall, T.Br.Gall)，テトラ-X.QnPh (T.Cl.QnPh, T.Br.QnPh), ジ -Cl.Gall, ジ -Cl. QnPh, ジ -Br.Gall, ジ -Br.QnPh (Cl.Gall, Br.Gall, Br.Gall, Br.QnPh) 体は, テトラ-Clあるいはテト ラ - $\mathrm{Br}$ 無水フタール酸と各多価フェノール，あるい はこれら縮合体のハロゲン化反応などにより得 た. 5,6,124,156,162) さらに, Gall, QnPh, T.Cl.Gall のメ チルエステル化により, Gall. $\mathrm{CH}_{3}, \mathrm{QnPh} . \mathrm{CH}_{3}$, T.Cl.Gall. $\mathrm{CH}_{3}$ を, またバニルフルオロン(Van.fl), サリチルフルオロン (Sal.fl), m- フルオロ .Phfl (F.Phfl) は，O- ヒドロキシヒドロキノンと各該当 フェノール体の縮合反応より得た， $1-8$ 位のいず れか 2 力所に $\mathrm{OH}$ 基を有する 3,6- ジヒドロキシ体 (フルオレセイン, $\mathrm{Fl}$ ), 及び 2,7- ジヒドロキシ体, 4,5- ジヒドロキシ体は，それぞれ無水フタール酸と

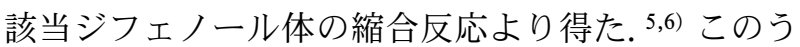
ち, Fl の対称並びに非対称型ハロゲン置換体は, それぞれ Fig. 2 の工程に従って合成し, 蛍光試薬 としての有用性をそのハロゲン $(\mathrm{X})$ 置換基の差異 より検索した. ${ }^{1,2,7)}$

すなわち，2,4,5,7- テトラ X.Fl, 2,7- ジ X.Fl, 4,5- ジ X.Fl の強アルカリ分解より得た X-2- (2,4ジヒドロキシベンゾイル）安息香酸（X-2,4-DBBA） と X-化レゾルシノールの縮合反応，あるいは Xレゾルシノールと無水フタール酸の縮合反応より, 

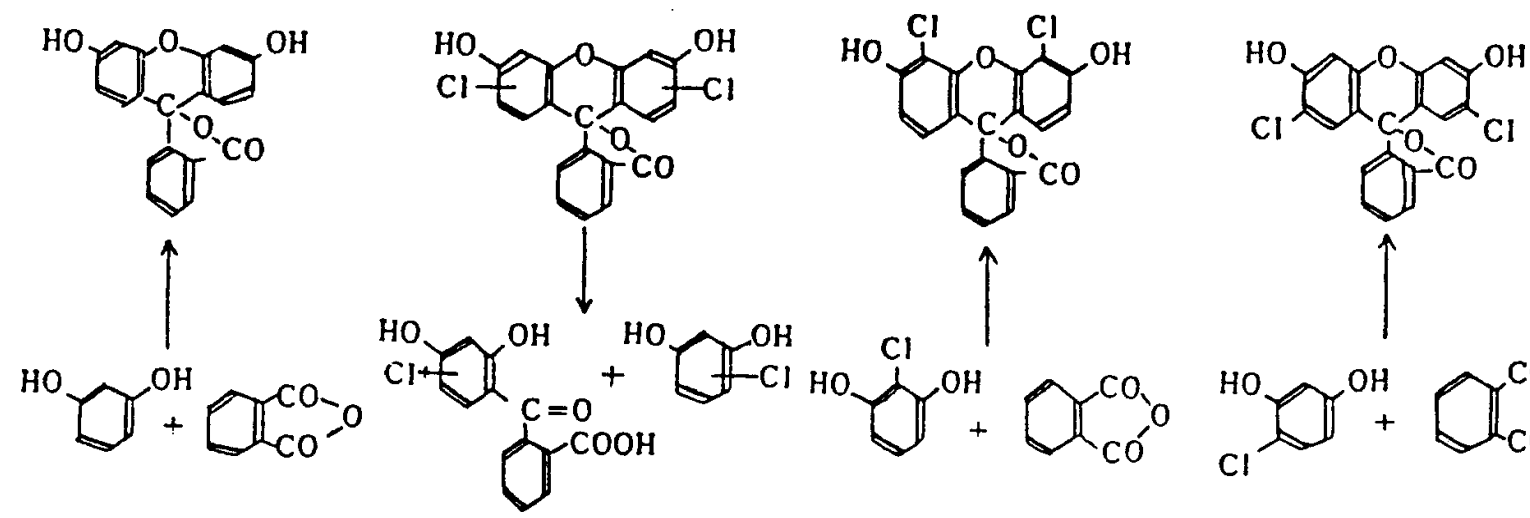

Fig. 2. Syntheses of Chlorofluoresceins

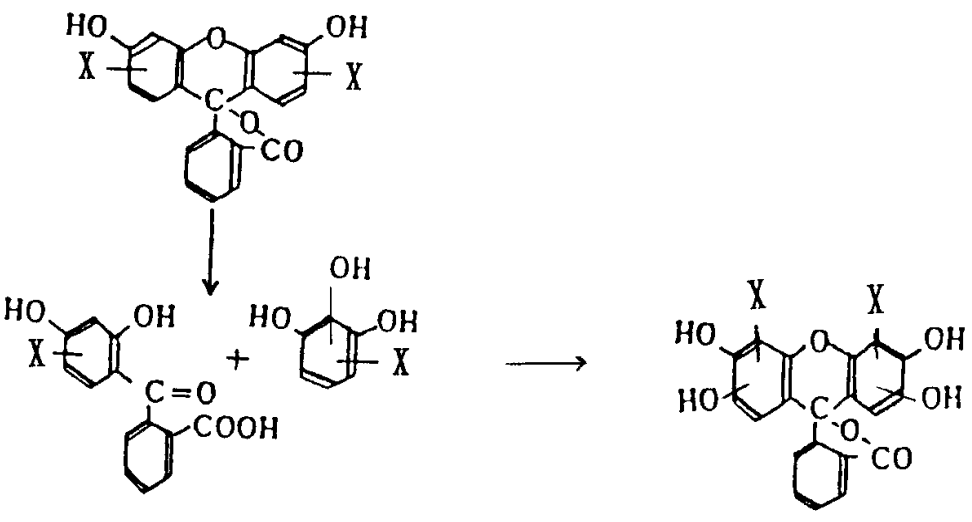

Fig. 3. Syntheses of Asymmetrical Hydroxyfluorans and Halogenohydroxyfluorans

並びに 2- モノ Cl.Fl, 4- モノ Cl.Fl, 2,4- ジ Cl.Fl, 2,5- ジ Cl.Fl, 2,7- ジ Cl.Fl, 4,5- ジ Cl.Fl, 2,4,7-トリ Cl.Fl, 2,4,5-トリ Cl.Fl, 2,4,5,7- テトラ Cl.Fl 体の 9 種, 2- モノ Br.Fl, 4- モノ Br.Fl, 2,4- ジ Br.Fl, 4,5ジ Br.Fl 体の 5 種, 並びに Cl-, Br-混合 $\mathrm{Fl}$ 体の 2-Br 7-Cl.Fl, 2-Cl 4-Br.Fl, 2-Br 5-Cl.Fl, 2,4-Br 7Cl.Fl, 2-Br 5,7-Cl.Fl, 2,7-Br 4-Cl.Fl, 2-Br 4,5-Cl.Fl 体などを合成した. ${ }^{3,4}$

1-1-2. 非対称型ヒドロキシフルオラン体：OH 基 を非対称に有する 3,6,7- 及び 3,6,8-トリヒドロキ シ体は，2,4-DBBA 誘導体と多価フェノールより得 た。さらに非対称型ヒドロキシフルオラン体の 2モノ，4- モノ，2,4- ジ位にX $(\mathrm{Cl}, \mathrm{Br}, \mathrm{I})$ 原子を有 するトリヒドロキシフルオラン体は，X-2,4-DBBA と多価フェノールの縮合反応より合成した（Fig. 3).5)

なお，これらトリヒドロキシフルオラン体のうち， 2,4- ジ Cl-3,5,6-トリヒドロキシ体及び 2,4- ジ
Cl-3,6,7-トリヒドロキシ置換体は, 試薬の安定 性, 溶解性の面, 並びに $\{\mathrm{M}\}$ との反応性において 他のトリヒドロキシ体より優れ, 明らかな X 原子 の助色団効果を観察したが，その反応性はテトラヒ ドロキシフルオラン体には及ばなかった. ${ }^{8-10)}$

1-1-3. ガリイン, フルオレスシン, フルオレセイ ンヒドラジド体 : Gall, Fl の亜鉛末還元により得た ガリイン (Gall.H), フルオレスシン $(\mathrm{Fl} . \mathrm{H})$ ，並び に $\mathrm{Fl}$ と $\mathrm{NH}_{2} \mathrm{NH}_{2}$ よりのフルオレセインヒドラジド 体 $\left.\left(\mathrm{Fl} . \mathrm{NHNH}_{2}\right)^{162}\right)$ は，いずれも蛍光試薬として利 用性大であった。

1-1-4. ハロゲン化フルオレセイン水銀体とマーキ ユロクロム：一般に，6-ヒドロキシ -3 H- キサンテ ン -3- オンは共鳴の結果, 2,4,5,7- 位で二重結合電 子の電子密度が大，また 1,3,6,8- 位では小なことよ り, Fl のように, 電子供与性の助色団の $\mathrm{OH}$ 基が 電子密度の小さい 6 位に 1 個結合すると蛍光性に都 合がよく, 蛍光量子収率は $\phi=0.97$ と大となる. な 
お, 日本薬局方（JP XIII）収載のマーキュロクロ ム（メルブロミン）， [2,7-dibromo-9- (O-crboxyphenyl ) -6-hydroxy-3-oxo-3 H-xantheone-4-yl ] hydroxymercury disodium salt は殺菌消毒剤として 利用されてきた。このマーキュロクロムの出発原 料, ジ -Br.Fl は Fl の直接臭素化反応体であり, そ の置換位は，2,7- 位でなく4,5-位であることを， これら単一及び混合 X.Fl の合成検討 ${ }^{4,13)} よ り$ 確認 できた.この Br.Fl誘導体の蛍光は, 出発物質の $\mathrm{Fl}$ に比べて弱く, また 4,5-Br.Fl の 2 あるいは 7 位に 電子吸引性の $\mathrm{HgOH}$ 基を有するマーキュロクロム は, 蛍光性が減少する。 さらに, Fl 及び 2,7-Cl.Fl の $\mathrm{Hg}$ 化反応の検討から, ${ }^{12,13)} \mathrm{pH} 4$ 付近, 6-4 倍 量の酢酸水銀を用い, 直火で約 10 時間の加熱還流 する反応条件が最良で，その Cl.Fl.Hg 化体は，い ずれもマーキュロクロムと同等の殺菌効果を示した (Table 1).

1-2. 芳香族アミン体, アゾ系誘導体とその他試 薬

1-2-1. 分子内に $-\mathrm{N} \equiv \mathrm{N}$ - と - $\mathrm{OH}$ 基, $-\mathrm{COOH}$ 基など の官能基をもつヒドロキシアゾ色素は, 染料あるい は顔料として利用されるとともに, 指示薬, 発色試 薬などとして分析化学面に大いに利用されている.

$\{\mathrm{R}\}$ として，ピリジルアゾナフトール (PAN), ピ リジルアゾレゾルシノール (PAR), ジンコン (Zincon) , 2-(5-ブロモ 2-ピリジルアゾ) 5- ジメチルア ミノフェノール (5-Br.PADAP) , 2 (5-ニトロ -2-ピ リジルアゾ) 5- (N-スルホプロピル)アミノ\} フェ ノール $\left(\mathrm{NO}_{2} . \mathrm{PAPS}\right)$ などを取り上げ， $\{\mathrm{M}\}$ との反 応性を各種界面活性剂の併用下に検索した。さらに, N- フエニル N- キノリルアミン誘導体の蛍光物質へ の転換反応についても検索した。

1-2-2. O-O 配位型の PR 及びその $\mathrm{Br}$ 体 (BPR), $\mathrm{PV}$ 並びにコンプレキソン体のキシレノールオレン ジ(XO), メチルチモルブルー(MTB), メチルキシ
レノールブルー $(\mathrm{MXB})$ 及びクロムアズロール -S （CRS）について, 新たな $\{\mathrm{M}-\mathrm{R}\}$ 錯体反応を各種 界面活性剂共存下に比較検討した。

\section{2. 有機試薬-金属イオン $\{\mathbf{R}-\mathbf{M}\}$ 間の反応}

2-1. キサンテン系誘導体の利用 $\mathrm{Fl}$ 誘導体, フタレイン系誘導体の中で $\{\mathrm{M}\}$ との反応性大なこ とを見出したテトラヒドロキシフルオラン体の QnPh, Gall, T.Cl.Gall, T.Cl.Gall. $\mathrm{CH}_{3}$, Sul.Phfl, 及 びマーキュロクロムの X-Fl.Hg 体 $\left(\mathrm{X}-\mathrm{Fl} . \mathrm{Hg}_{4}\right)$ など を $\{\mathrm{R}\}$ に取り上げ, $\mathrm{Mo}(\mathrm{VI}), \mathrm{Th}(\mathrm{IV}), \mathrm{Ce}(\mathrm{III}), \mathrm{Sn}$ (IV)などの $\{\mathrm{M}\}$ 間の発色及び蛍光反応を追跡し, より高感度, 簡便, 迅速な新規定量法の開発を目的 とした。この際, ヘキサメチルピリジニウム塩 (HPC, CPC) のごとき長鎖第 4 級アンモニウム塩 の陽イオン性界面活性剤, ラウリル硫酸ナトリウム （SLS）のごとき陰イオン性界面活性剂, Tween 20 のごとき非イオン性界面活性剂, ザルコシンのごと き両イオン性界面活性剂などの単独, あるいはそれ ら組合せ下の $\{\mathrm{M}\}$ と $\{\mathrm{R}\}$ 間の錯体生成反応を系 統的に検索し, 各種金属イオン及び非金属イオン $\{\mathrm{M}\}$ の定量法を多数開発した.

2-1-1. 発色反応の活用: 近年, 光分析法における クロロホルム, n- ブチルアルコール, イソアミル アルコールなど毒性の有機溶媒使用を避け, 実験操 作の単純化, 感度及び選択性の向上を期待した各種 界面活性剂の併用が種々検討されてきた。一般に,

$\{\mathrm{M}-\mathrm{R}\}$ 反応への界面活性剤の共存は, 低 $\mathrm{pH}$ での 錯形成, 吸収スペクトルのレッドシフト, $\varepsilon$ の増 大, 選択性の向上, 錯体の可溶化, ミセル増感効果 などより，界面活性剂の併用効果が注目を集めてい る.これら現象は, ミセル界面での発色試薬の酸解 離の促進, 高次錯体の生成し易さなど，ミセル界面 下での錯体の励起状態の安定化によるとされてい る。しかしながら, 真溶液内の現象とは異なり, 界 面活性剂併用下の擬均一系での平衡解析は大きな難

Table 1. Fluorescein (Fl) and Halogeno-Fl Derivatives Mercury ( $\mathrm{Hg}$ )-Compounds

\begin{tabular}{rcccccccc}
\hline \hline Fl derivatives $\mathrm{Hg}$ & 2 & 4 & 5 & 7 & $3^{\prime}$ & $4^{\prime}$ & $5^{\prime}$ & $6^{\prime}$ \\
\hline Fl. $\mathrm{Hg}_{4}$ & $\mathrm{HgOH}$ & $\mathrm{HgOH}$ & $\mathrm{HgOH}$ & $\mathrm{HgOH}$ & $\mathrm{H}$ & $\mathrm{H}$ & $\mathrm{H}$ & $\mathrm{H}$ \\
$2,7-\mathrm{Cl} . \mathrm{Fl} . \mathrm{Hg}_{2}$ & $\mathrm{Cl}$ & $\mathrm{HgOH}$ & $\mathrm{HgOH}$ & $\mathrm{Cl}$ & $\mathrm{H}$ & $\mathrm{H}$ & $\mathrm{H}$ & $\mathrm{H}$ \\
$2,4-\mathrm{Cl} . \mathrm{Fl} . \mathrm{Hg}_{2}$ & $\mathrm{Cl}$ & $\mathrm{Cl}$ & $\mathrm{HgOH}$ & $\mathrm{HgOH}$ & $\mathrm{H}$ & $\mathrm{H}$ & $\mathrm{H}$ & $\mathrm{H}$ \\
$3^{\prime}, 4^{\prime}, 5^{\prime}, 6^{\prime}-\mathrm{Cl} . \mathrm{Fl} . \mathrm{Hg}_{4}$ & $\mathrm{HgOH}$ & $\mathrm{HgOH}$ & $\mathrm{HgOH}$ & $\mathrm{HgOH}$ & $\mathrm{Cl}$ & $\mathrm{Cl}$ & $\mathrm{Cl}$ & $\mathrm{Cl}$ \\
Mercurochrome & $\mathrm{H}$ & $\mathrm{Br}$ & $\mathrm{Br}$ & $\mathrm{HgOH}$ & $\mathrm{H}$ & $\mathrm{H}$ & $\mathrm{H}$ & $\mathrm{H}$ \\
\hline
\end{tabular}


問を有する。これら事害解明を目的に，キサンテン 系誘導体の中で利用価值大と判断された $\mathrm{QnPh}$ を $\{\mathrm{R}\}$ に，また $\{\mathrm{M}\}$ に弱酸性域下でエチレンヂア ミン四酢酸 (EDTA) のごときマスク剤共存の影響 を受け難い $\mathrm{UO}_{2}^{+}$を選び, $\left\{\mathrm{QnPh}-\mathrm{UO}_{2}^{+}\right\}$間反応へ の各種界面活性剂併用効果 (陽, 陰, 非, 両イオン 性）を系統的に検索した. ${ }^{42)}$

一般に，陽イオン性界面活性剤と有機試薬 $\{\mathrm{R}\}$ を併せ使用すると, 発色錯体の吸収帯は長波長へシ フトし, その吸収強度も増大する共通特徵が見られ る. 陽イオン性界面活性剂は長い炭化水素鎖の一端 に第 4 級窒素の正電荷を有することより, 炭化水素 鎖が疎水性基，第 4 級窒素が親水性基として界面活 性効果を現すが，炭化水素鎖があまり短いと疎水性 は十分発揮されず，炭素数 4 以上で疎水性が強くな り水溶液内で分子が集合したミセルを形成する。し たがって，ミセル限界濃度 (CMC) 以上, 例えば, $\mathrm{HTAC}$ を $1 \times 10^{-4} \mathrm{~mol} \mathrm{cmc}$ 以上に添加すると, 正 電荷の密度の高い部分が生成することになる．分析 化学の分野で一般的に使用される陽イオン性界面活 性剂は, 水溶性のテトラデシルジメチルベンジルア ンモニウムクロリド (Zephiramine) $\quad\left[\mathrm{CH}_{3}\left(\mathrm{CH}_{2}\right)_{13}\right.$ $\left.\mathrm{N}\left(\mathrm{CH}_{3}\right)_{2} \mathrm{C}_{6} \mathrm{H}_{5}\right] \mathrm{Cl}, \quad \mathrm{CTAC}(\mathrm{HTAC}) \quad\left[\mathrm{CH}_{3}\left(\mathrm{CH}_{2}\right)_{16}\right.$ $\left.\mathrm{N}\left(\mathrm{CH}_{3}\right)_{3}\right] \mathrm{Cl}, \mathrm{CPC}(\mathrm{HPC}) \quad\left[\mathrm{CH}_{3}\left(\mathrm{CH}_{2}\right)_{15} \cdot \mathrm{NC}_{5} \mathrm{H}_{5}\right] \mathrm{Cl}$ などである。これより $\mathrm{QnPh}$ のごときキサンテン 系色素の解離型のイオン種の濃度が増大し, $\mathrm{pH}$ が 低下してくる. 色素分子の $\mathrm{OH}$ 基の $\mathrm{pK}_{\mathrm{a}}$ が小さい ものほど界面活性剂の影響が大で, 色素分子の解離 型に対応する吸収帯の極大吸収波長もミセルとの相 互作用でレッドシフトする. 一方, $\mathrm{pK}_{\mathrm{a}}$ の大きな色 素に対しては, $\mathrm{OH}$ 基の解離に及ぼすミセルの効果 は少ない。一般的に，錯生成反応は配位子のプロト ンが $\{\mathrm{M}\}$ と置換される反応であり, 溶液の $\mathrm{pH}$ が 高く, 配位子のプロトン解離の進行に比例した錯生 成が促進される，ミセルが存在すれば，配位子のプ ロトンは解離して錯生成が容易となり, 高次錯体の 生成が進行する。 また, 生成錯体が陰イオン性の場 合, 錯体とミセル正電荷の相互作用により色素配位 子のプロトン解離は促進され, 吸収強度の大きな錯 体を生成する。フタレイン系試薬の $\mathrm{QnPh}$ につい ても, HTACのごとき水溶性陽イオン性界面活性 剂の併用は，XO，PV などの場合と同じように配位 子の酸解離促進, ミセル界面への濃縮現象が観察さ
れた。すなわち, $\mathrm{QnPh}$ もフェノール性水酸基 3 個 とカルボキシル基 1 個を有することより, 中性キノ イド型構造の $\mathrm{H}_{4} \mathrm{QnPh}^{0}$ と強酸性下の $\mathrm{QnPh}$ にプロ トンが付加したカチオン型構造の $\mathrm{H}_{5} \mathrm{QnPh}^{+}$並びに その解離型の計 6 種のイオン種より, $\mathrm{pK}_{\mathrm{a} 0}, \mathrm{pK}_{\mathrm{a} 0}-$ $\mathrm{pK}_{\mathrm{a} 4}$ が存在する.

$$
\begin{aligned}
& \mathrm{H}_{5} \mathrm{QnPh}^{+} \underset{\mathrm{K}_{\mathrm{a} 0}}{\rightarrow} \mathrm{H}_{4} \mathrm{QnPh}^{0} \underset{\mathrm{K}_{\mathrm{a} 1}}{\rightarrow} \mathrm{H}_{3} \mathrm{QnPh}^{-} \underset{\mathrm{K}_{\mathrm{a} 2}}{\rightarrow} \\
& \mathrm{H}_{2} \mathrm{QnPh}^{2-} \underset{\mathrm{K}_{23}}{\rightarrow} \mathrm{HQnPh}^{3-} \underset{\mathrm{K}_{24}}{\rightarrow} \mathrm{QnPh}^{4-}
\end{aligned}
$$

これら $\mathrm{pK}_{\mathrm{a}}$ を分光学的に界面活性剂共存及び共存 しない場合について，それぞれ算出した（Table 2)。同じように, 非イオン性界面活性剤のアラビア ゴム末 (gum), 陽イオン性界面活性剂の HTAC, 陰イオン性界面活性剤のSLS などの共存下におけ る酸解離定数を求めた。これら表, 図より明らかな ように, HTACのごとき陽イオン性界面活性剤の 共存は, $\mathrm{QnPh} の \mathrm{pK}_{\mathrm{a} 1}$ を 2.46 より $2.05, \mathrm{pK}_{\mathrm{a} 2}$ を 5.82 より 5.25 と変動させ, HTAC 共存による酸解 離の促進が認められた（Fig. 4, 5).

ついで, $\mathrm{QnPh}$ と $\{\mathrm{M}\}$ との反応が, 主として酸 性より中性域にまたがる U (VI)を $\{\mathrm{M}\}$ として取 り上げ, $\mathrm{QnPh}$ との発色性を検索したところ, 陽イ オン性界面活性剤の併用は反応領域を $\mathrm{pH} 7.3$-8.8 より 7.5-9.2へと拡大し，その見掛けのモル吸光 係数 $(\varepsilon)$ も $2.7 \times 10^{4}$ (組成 $1: 1$ モル比) より 9.4 $\times 10^{4}$ (1:2 モル比) へと増大（陰イオン性界面活 性剂の共存で, $\mathrm{pH} 7.5-9.2, \varepsilon=2.7 \times 10^{4}$, 組成 1 : 1 モル比), 42,114) 界面活性剂の差異による発色変化 が明瞭であった（Fig. 6)。以下に，陽イオン性界 面活性剂の併用効果が観察された $\{\mathbf{M}\}$ の定量を陽 イオン性界面活性剤（HPC, HTAC, Zp, TTACな ど）別に, 使用した $\{\mathrm{R}\}$ （Gall, QnPh, Phfl, Cl.Gall. $\mathrm{CH}_{3}, \mathrm{Fl} . \mathrm{NHNH}_{2}, \mathrm{MXB}, \mathrm{PR}$ など）とともに記述す る.

HPB or HPC の使用例 $\cdots$ Gall-Sn (IV), 20) QnPh-

Table 2. Acid Dissociation Constant $\left(\mathrm{pK}_{\mathrm{a} 1}-\mathrm{pK}_{\mathrm{a} 3}\right)$ of $\mathrm{QnPh}$ in the Presence or Absence of Surfactant

\begin{tabular}{c|cccc}
\hline \hline Resagent & Surfactant & $\mathrm{pK}_{\mathrm{a} 1}$ & $\mathrm{pK}_{\mathrm{a} 2}$ & $\mathrm{pK}_{\mathrm{a} 3}$ \\
\hline $\mathrm{QnPh}$ & - & 2.46 & 5.82 & 7.06 \\
$\mathrm{QnPh}$ & Nonionic & 2.44 & 5.50 & 6.79 \\
$\mathrm{QnPh}$ & Cationic & 2.05 & 5.21 & 6.22 \\
QnPn & Anionic & 2.44 & 5.52 & 6.76 \\
\hline
\end{tabular}




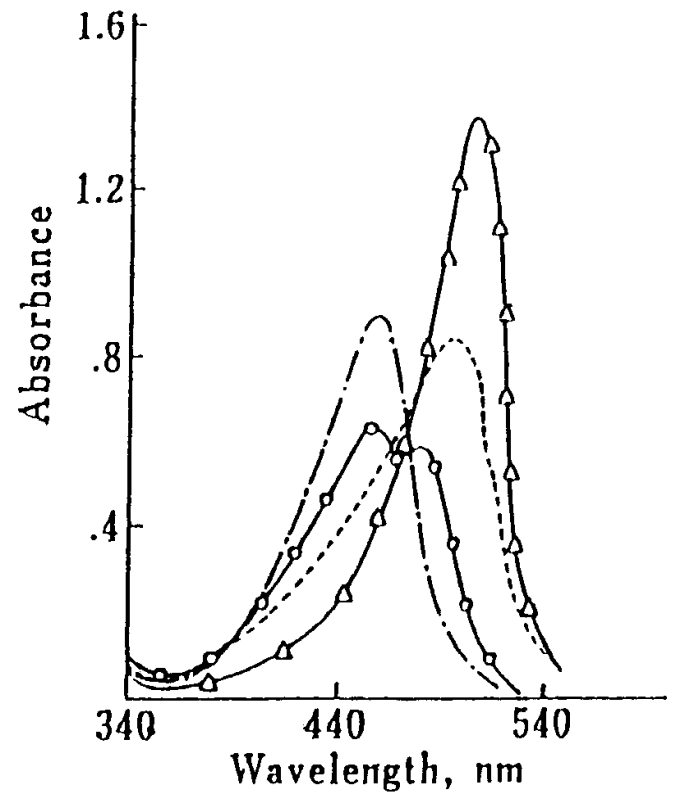

Fig. 4. Absorption Spectra of QnPh Solution at Various $\mathrm{pH}$ 's

QnPh: $2.5 \times 10^{-5} \mathrm{~mol} / \mathrm{l}, \mu=0.1$, reference: water

- - —: pH 1.55, —०—: pH 3.28, …: $\mathrm{pH} 6.26,-\triangle-: \mathrm{pH} 7.63$.

Ge (IV) , ${ }^{73)}$ Gall-Ge(IV), 30) Phfl-Mo(VI), 32) QnPhFe (III ) , ${ }^{31)}$ Gall-Fe ( III ) ,28) QnPh-In (III) , ${ }^{90)}$ T.Cl.Gall-In ( III ) , ${ }^{37)}$ Gall-Ga (III) , ${ }^{39)}$ Gall-Th (IV), 102) Cl.Gall. $\mathrm{CH}_{3}-\mathrm{Th}$ (IV), ,27) QnPh-Hf(III), 70) Cl.Gall. $\mathrm{CH}_{3}$-Rare (III) , ${ }^{17)}$ PR-Mo(VI), ${ }^{49)}$ MXB-Th (VI) ${ }^{26)}$ MXB-Ce (III) ${ }^{18)}$ また, HTAC, Zp, BSTAC, TTAC の使用例 $\cdots$ QnPh-U (VI) ${ }^{42)}$ Gall-W (VI), 33) QnPh-Cr (III) , ${ }^{46)}$ Sulf.Phfl-Pd (II), 157) QnPh-Ga (III), 106) QnPh-Ga (III), ${ }^{152)}$ QnPh-Ni(II), 128) QnPh$\mathrm{Ta}(\mathrm{III}),{ }^{133)}$ QnPh-Nb (III), ${ }^{136)}$ T.Cl.Gall-Th (IV), ${ }^{55)}$ Fl. $\mathrm{NHNH}_{2}-\mathrm{H}_{2} \mathrm{O}_{2}-\mathrm{Co}(\mathrm{II}) .{ }^{162)}$

2 種以上の界面活性剂の組夕合わせ例として，陽 イオン性界面活性剂のミセル生成の助剂に非イオン 性界面活性剂の組み合わせ $\cdots \mathrm{Zp}$ と Brij 35 の組み合 わせ下に $\mathrm{QnPh}$ を用いる $\mathrm{Al}(\mathrm{III})$ 定量法が, ${ }^{103)} \varepsilon=$ $2.1 \times 10^{5}$ (XO 法のほぼ 10 倍) の鋭敏度で, 日常汎 用の $\mathrm{Al}$ 箔製簡易鍋より一部 $\mathrm{Al}$ (III) が溶出するこ とも報告した（Table 3)。ささらに, 両イオン性界面 活性剤の単独あるいはその組合わせ例として, LS と Brij 35 が \{PAR-Ce(III) \}, ${ }^{87)}$ \{Gall-Th(IV) \} ${ }^{96)}$ に用いられた。 その他, 陽イオン性とその他活性剂 の組み合わせ例 $\cdots H$ HTAC と MC が $\{\mathrm{QnPh}-\mathrm{Pd}(\mathrm{II})\}, 45)$ HPC と PVA が $\left\{\right.$ T.Cl.Gall-V (V) \}, ${ }^{92)}$ HPC と Brij が $\{$ QnPh-Gd (III) \}, 142) $\{$ XO-Zr (IV) $\}, 108)$ さらに

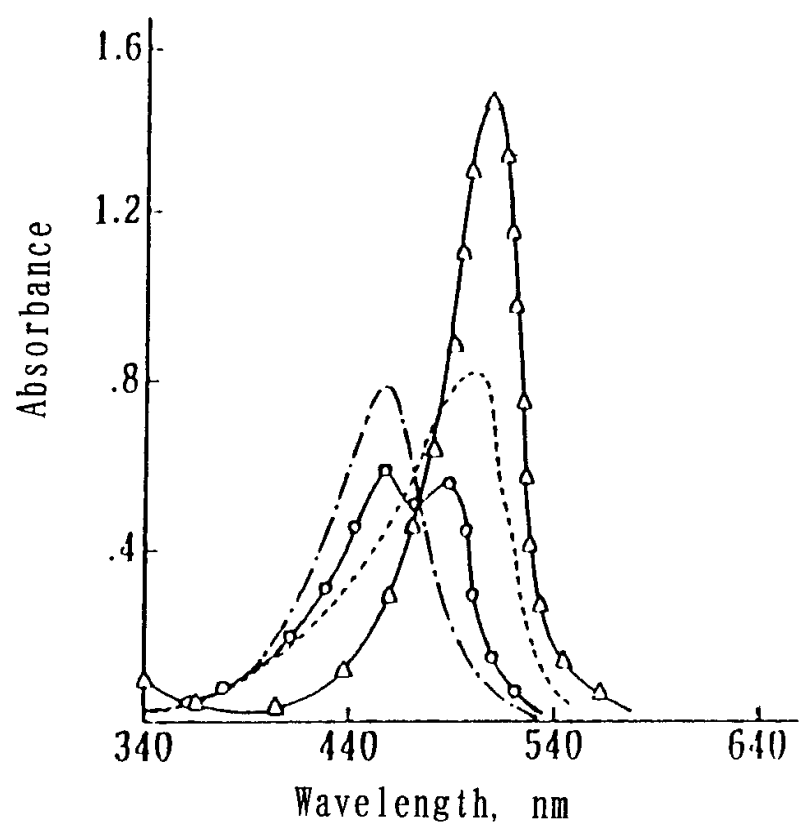

Fig. 5. Absorption Spectra of QnPh Solution at Various $\mathrm{pH}$ 's in the Coexistence of HTAC

QnPh: $2.5 \times 10^{-5} \mathrm{~mol} / 1$, HTAC: $2.0 \times 10^{-3} \mathrm{~mol} / 1, \mu=0.1$, reference: water.

- - : $\mathrm{pH} 1.50,-\mathrm{-}: \mathrm{pH} 2.88, \cdots \cdots \cdot \mathrm{pH} 5.95,-\triangle-: \mathrm{pH} 7.21$.

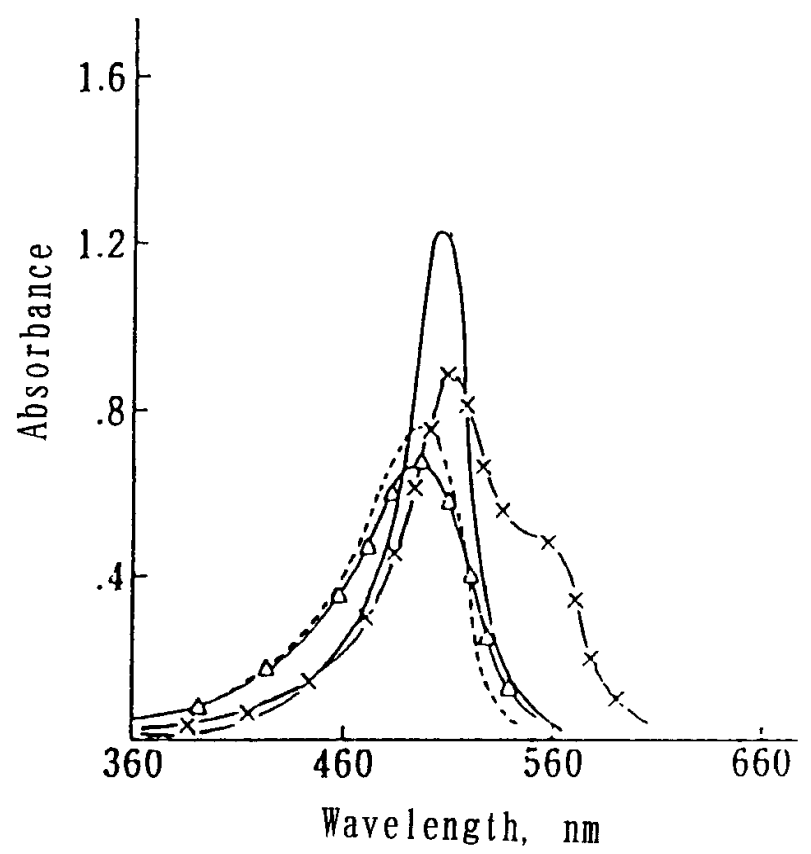

Fig. 6. Absorption Spectra of QnPh Solution and $\{\mathrm{QnPh}-\mathrm{U}$

(VI) $\}$ Complex Solution at $\mathrm{pH} 6$

$\mathrm{U}(\mathrm{VI}): 5.0 \times 10^{-6} \mathrm{~mol} / \mathrm{l}, \quad$ QnPh: $2.5 \times 10^{-5} \mathrm{~mol} / \mathrm{l}$, surfactant: $1.0 \times$ $10^{-3} \mathrm{~mol} / \mathrm{l}$, reference: water.

QnPh-HTAC, - $\times$ - QnPh-U (VI)-HTAC, .......: QnPhSLS, QnPh-Tween 20, - - - $\{$ QnPh-U (VI)-SLS $\},\{\mathrm{QnPh}-\mathrm{U}(\mathrm{VI})-\mathrm{T}$ ween $20\}$. 
Table 3. Effects of Surfactants on the Color Reactions between QnPh and Al (III)

\begin{tabular}{|c|c|c|c|c|c|}
\hline \multirow{2}{*}{ Cation } & \multicolumn{3}{|c|}{ Surfactants } & \multirow{2}{*}{$\begin{array}{c}\text { Absorbance } \\
\text { at } \lambda_{\max }\end{array}$} & \multirow{2}{*}{$\lambda_{\max }$} \\
\hline & Nonionic & Anionic & Amphoteric & & \\
\hline $\mathrm{Zp}$ & Brij 35 & - & - & 555 & 0.650 \\
\hline- & - & - & - & 515 & unstable \\
\hline - & Brij 35 & - & - & 515 & 0.170 \\
\hline HTAC & Brij 35 & - & - & 555 & 0.460 \\
\hline HTAC of Zp & - & - & - & 555 & unstable \\
\hline $\mathrm{HTAC}+\mathrm{Zp}$ & - & - & - & 555 & unstable \\
\hline- & - & SDS & - & 520 & unstable \\
\hline - & - & - & LS & 520 & unstable \\
\hline - & Brij 35 & - & LS & 520 & 0.065 \\
\hline - & Brij 35 & SDS & - & 518 & 0.218 \\
\hline - & Tween $20+$ Brij 35 & - & - & 515 & 0.158 \\
\hline
\end{tabular}

$\mathrm{Al}(\mathrm{III}): 0.8 \mu \mathrm{g} / 10 \mathrm{ml}$, QnPh: $\left.7.5 \times 10^{-5} \mathrm{M}\right)$.

HTAC と Triton Xが $\{$ QnPh-Co (II) $\}{ }^{107)}$ に用いら れた.

他方, 脂溶性陽イオン性界面活性剂トリオクチル メチルアンモニウムクロリド (Aliquat 336, Capriquat) $\left[\left(\mathrm{CH}_{3}\left(\mathrm{CH}_{2}\right)_{7}\right)_{3} \mathrm{NCH}_{3}\right] \mathrm{Cl}$ あるいは 1,3- ジフ エニルグアニジン（DPG）などを共存させ， \{Cl.Gall. $\left.\mathrm{CH}_{3}-\mathrm{Bi}(\mathrm{III})\right\}$ あるいは $\{$ Gall-Sn(IV) $\}$ の 電荷を中和した後, イソブチルアルコールなどの非 極性有機溶媒抽出により, ${ }^{16,21)}$ 水相内定量法に比 べ，ほぼ 10 倍の鋭敏度を得た。同じ現象は，DPG 共存下の MTB-Bi (III) 間でも認め, 水相内定量法に

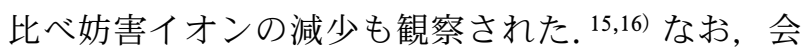
合錯体のような新たな反応体生成の外, 水溶性界面 活性剂の併用は, 生成体の水溶液内分散, 擬溶液生 成による水溶化，安定化の増大が期待される．すな わち，水溶性界面活性剂の併用による不溶性錯体の 可溶化により, 毒性有機溶媒使用の回避, 抽出操作 の省略による分析時間の短縮, 並びに錯体生成速度 の短縮，吸光度の増大などの現象が期待される。こ れら界面活性剂の併用効果を, 陽イオン性界面活性 剂 ‥ Gall-Sn(IV ), ${ }^{20)}$ Gall-Ge( IV) あるいは QnPh-Ge (IV) ${ }^{30,73)}$ 反応などで観察された。さらに 非イオン性界面活性剂共存による生成体の可溶化, 呈色の安定化, 吸光度の上昇などの現象が…ゼラチ ンの使用の QnPh-Sn (IV) , ${ }^{38)} \mathrm{Cl}$.Gall. $\mathrm{CH}_{3}-\mathrm{Sb}$ (III) , ${ }^{15)}$ ポリビニルアルコール (PVA) の使用の Qnph-Sb (III), 129) Van.fl-Sb(III), ${ }^{129)}$ QnPh-U(VI), QnOh-W (VI), 114) QnPh-Cu(II), ,40) PR-Sm (III), ,99) Tween の
使用の QnPh-Mo(VI), ${ }^{41)}$ QnPh-Ti(IV) , ${ }^{60)}$ Brij 35 の 使用の QnPh-Fe(III), ${ }^{121)}$ QnPh-Bi(III), ${ }^{109)}$ Gall-Os ${ }^{141)}$ 間で，それぞれ認め，これら新規定量法を確立でき た.

なお，第三の配位子 $\{\mathrm{Org}\}$ を共存させ， $\{(\mathrm{R}-\mathrm{M})$ -Org $\}$ 会合体反応を活用する $\{\mathrm{M}\}$ 定量例として, $\{\mathrm{Org}\}$ に 1,10-フェナントロリン(Phen) を用いる $\mathrm{Ag}$ (I) 定量が Cl.Gall. $\mathrm{CH}_{3},{ }^{35)}$ T.Cl.Fl ${ }^{31)}$ で，また \{Org\} にアデニン (Aden), $\{\mathrm{R}\}$ にエオシン (Eosine) を用いる $\mathrm{Ag}(\mathrm{I}){ }^{146)}$ 定量が， $\Delta \mathrm{G}=-6.34, \Delta \mathrm{H}=-$ $28.17, \Delta \mathrm{S}=-72.73, \mathrm{n}=0.98, \mathrm{k}=4.10 \times 10^{4} \mathrm{~mol}^{-1}$ で 行われた。同じような会合錯体 $\{(\mathrm{R}-\mathrm{M})-\mathrm{Org}\}$ 反 応例として, $\{\mathrm{Org}\}$ に有機塩基のパパベリン (Papav), サイアミン (Thiam), ジブカイン (Dibuc) などを, $\{\mathrm{R}\}$ に Fl 系のフロキシン (Phloxin) を用いるとき, $\mathrm{Pd}(\mathrm{II})$ との間に $\{(\mathrm{R}-\mathrm{M})$ -Org \} 会合体の形成反応が, Thiamine を用いて, ${ }^{119)}$ またメチルセルローズ (MC) 共存下， $\{\mathrm{Au}(\mathrm{III})$ $\left.(\text { Thiam })_{2}\right\} \quad(\text { Phlox })_{2}$ の会合体を用いて， 0.2-8 $\mu \mathrm{g} /$ $10 \mathrm{ml} \mathrm{Au}$ (III) が定量できた (Table 4). ${ }^{166)}$

さらに, サポニンの $\mathrm{Fe}(\mathrm{III})$ 定量への応用におけ るサポニンの界面活性剂類似作用は, サポニンのミ セル表面の疎水基の糖グループと $\mathrm{Fe}$ (III) が疎水相 互作用するものと推測した（Table 5). 105）また, $\{\mathrm{M}\}$ とキレート形成能をもつ天然キレート剂で吸 着剤などに用いられているキトサンを $\mathrm{QnPh}$ と $\mathrm{Zn}$ (II) 間反応に用い, HTACにも優る効果で安定 性, 感度の上昇, 妨害イオンの減少などの利点を見 
Table 4. Effects of Organic Bases $\{$ Org $\}$ by Using Four Fl Dyes $\{\mathbf{R}\}$

\begin{tabular}{l|cccc}
\hline \hline \multirow{1}{*}{ Org } & \multicolumn{4}{|c}{ Absorbance at $\left(\lambda_{\text {nm }}\right)$} \\
& Phloxine & Eosine & $\begin{array}{c}\text { Rose } \\
\text { Bengal }\end{array}$ & $\begin{array}{c}\text { Erythro- } \\
\text { sine }\end{array}$ \\
\hline \multirow{2}{*}{ Thiamine } & 0.610 & 0.510 & 0.615 & 0.501 \\
& $(565)$ & $(545)$ & $(580)$ & $(560)$ \\
Papaverine & 0.134 & 0.153 & 0.103 & 0.095 \\
& $(575)$ & $(540)$ & $(565)$ & $(560)$ \\
Dibucaine & 0.153 & 0.097 & 0.102 & 0.079 \\
& $(575)$ & $(540)$ & $(565)$ & $(560)$ \\
Scopolamine & 0.089 & 0.072 & 0.096 & 0.096 \\
& $(545)$ & $(540)$ & $(565)$ & $(535)$ \\
Pilocarpine & 0.144 & 0.079 & 0.276 & 0.099 \\
& $(565)$ & $(540)$ & $(575)$ & $(535)$ \\
\hline
\end{tabular}

Pd (II) : $6.0 \times 10^{-6} \mathrm{~mol} / \mathrm{l},\{\mathrm{R}\}: 1.5 \times 10^{-4} \mathrm{~mol} / \mathrm{l}, \mathrm{HPC}: 0.005 \%$.

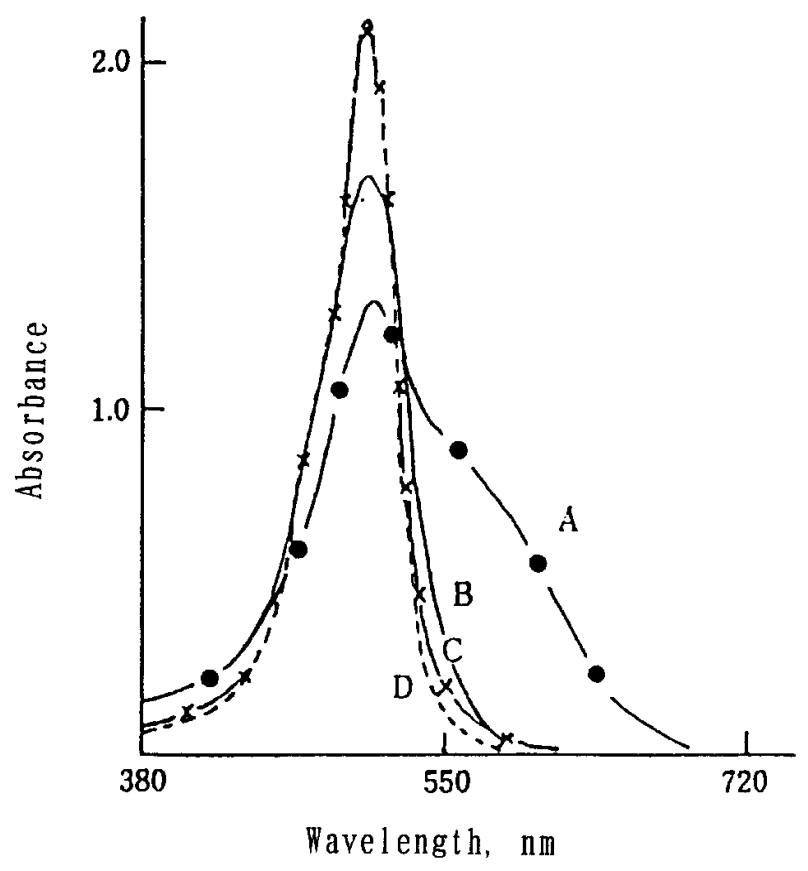

Fig. 7. Absorption Spectra of $\{\mathrm{QnPh}-\mathrm{Fe}(\mathrm{III})\}$ and QnPh Solution in the Presence or Absence of Saponin

$\mathrm{Fe}(\mathrm{III}): 8.0 \times 10^{-6} \mathrm{~mol} / \mathrm{l}$, saponin: $0.2 \%$, QnPh: $4.0 \times 10^{-5} \mathrm{~mol} / \mathrm{l}, \mathrm{pH}$ 9.3, reference: water.

Curve A: $\{\mathrm{QnPh}-\mathrm{Fe}(\mathrm{III})$-saponin $\}$ solution, Curve B: QnPh-saponin solution, Curve C: $\{\mathrm{QnPh}-\mathrm{Fe}(\mathrm{III})\}$ solution, Curve D: QnPh solution.

出した（Fig. 7).125)

2-1-2. 蛍光性の活用: 蛍光の活用は, (1)試薬一金 属イオン $\{(\mathrm{R}-\mathrm{M})\}$ 反応で, 蛍光性物質に変換さ れる場合, (2)蛍光性ある試薬 $\{\mathrm{R}\}$ が $\{\mathbf{M}\}$ と反応 して蛍光強度変化を示す場合に分けられる.

6-ヒドロキシ -3 H- キサンテン -3- オンは共鳴の 結果, 2,4,5,7- 位で二重結合電子の電子密度が大, 1,3,6,8- 位で電子密度が小で，3,6- ジ OH 体の Fl
Table 5. Effect of Surfactants on the Reactions between $\mathrm{QnPh}$ and Fe (III)

\begin{tabular}{lc||lc}
\hline \hline Surfactants & $\begin{array}{c}\text { Absorbance } \\
\text { difference }\end{array}$ & Surfactants & $\begin{array}{c}\text { Absorbance } \\
\text { difference }\end{array}$ \\
\hline None & $0.070(535)$ & Saponin & $0.590(565)$ \\
Dextran & $0.472(555)$ & Acacia & $0.362(560)$ \\
CMC & $0.164(555)$ & Na-arginate & $0.192(555)$ \\
HTAC & $0.112(580)$ & CPC & $0.080(580)$ \\
SDS & $0.100(560)$ & LS & $0.058(565)$ \\
PEG 4000 & $0.062(565)$ & PVA & $0.248(565)$ \\
PVP & $0.052(570)$ & Gelatin & $0.102(570)$ \\
Tween 20 & $0.082(560)$ & Triton X100 & $0.123(560)$ \\
Brij 35 & $0.047(565)$ & & \\
\hline
\end{tabular}

Difference of absorbance between $\{\mathrm{QnPh}-\mathrm{Fe}(\mathrm{III})\}$ and $\mathrm{QnPh}$ soln. $\mathrm{Fe}(\mathrm{III}): 5.0 \times 10^{-6} \mathrm{~mol} / \mathrm{l}$, QnPh: $1.5 \times 10^{-4} \mathrm{~mol} / 1, \mathrm{pH} 9.5$.

のように, 電子供与性の助色団の $\mathrm{OH}$ 基が電子密 度の小さい 6 位に 1 個結合すると蛍光性に都合がよ い（蛍光量子収率 $\phi=0.97 ）$ 。サンテン環に 4 つ の $\mathrm{OH}$ を有するテトラヒドロキシ体では, 2,3,6,7-OH 位 $(\mathrm{QnPh})$ が，わずかに蛍光性を示し, 蛍光試薬としての利用性が考えられるのに対し, 3,4,5,6-OH (Gall) , 1,3,6,8-OH のフロログルシンフ タレインは全く蛍光を示さず, 蛍光試薬としての利 用性はない。一方， Fl の X 化体あるいはニトロ置 換体では，2,7- 置換体よりも 4,5- 置換体が消光性 大である. ${ }^{14)}$ 本事実より，(2)に分属する試薬でわず かに蛍光を有する $\mathrm{QnPh}$ ，錯形成を有しないが強い 蛍光性を示す Fl 誘導体の Phloxine, マーキュロク ロムなどの X.Fl.Hg 置換体など12)について, 蛍光 試薬としての活用性を検索した。 QnPhの蛍光性を 利用した $\{\mathrm{M}\}$ 蛍光定量例 $\cdots \mathrm{QnPh}-\mathrm{Sn}(\mathrm{IV}),{ }^{38)}$ QnPh-Mo(VI), ${ }^{41)}$ QnPh-U(VI), QnPh-W (VI), ${ }^{114)}$ QnPh-Fe (III), 121) QnPh-V(V)- アスコルビン酸, ${ }^{112)}$ QnPh-Ga (III) , ${ }^{152)} \mathrm{QnPh}-\mathrm{Zr}(\mathrm{IV})^{152)}$ などへの蛍光定 量 (Ex $400 \mathrm{~nm}$ 又は $345 \mathrm{~nm}, \mathrm{Em} 535$ 又は $520 \mathrm{~nm}$ ) を確立した（Fig. 8）（Table 6）。蛍光強度の測定に 際し, 分散剂, 安定剂として非イオン性界面活性剂 の PVA，ポリビニルピロリドン (PVP), Tween 20 などの共存が最適で, $\mathrm{Ga}(\mathrm{III})$ にはテトラデシルト リメチルアンモニウム塩 (TTAC) の添加が有効で あった. ${ }^{152)}$ X.Fl 体のエオシン (Eosin) の蛍光性が,

$\{$ Eosin- アデニン $-\mathrm{Ag}(\mathrm{I})\}$ 会合反応で $\mathrm{Ag}(\mathrm{I})$ 蛍光定 量に活用された。 ${ }^{146)}$ また， $\{\mathrm{M}\}$ と $\{\mathrm{R}\}$ 間の呈色 反応がほとんど認められない痕跡量の $\{\mathrm{M}\}$ の定量 


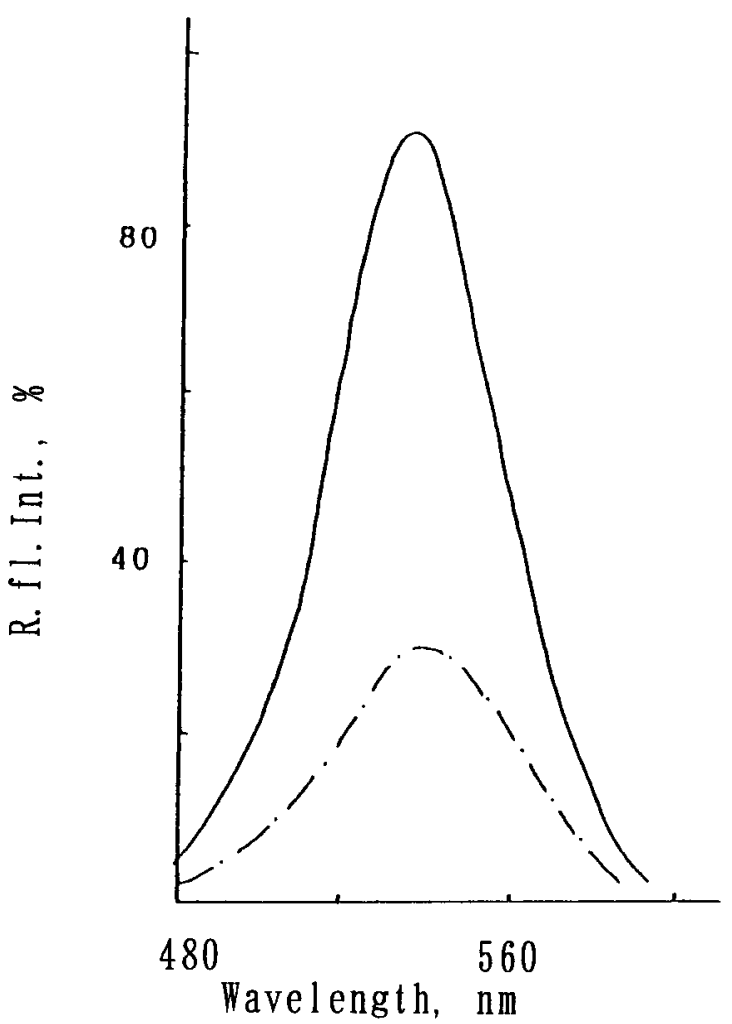

Fig. 8. Absorption Spectra QnPh-L-Ascorbic Acid Solution and $\{\mathrm{QnPh}-\mathrm{L}-\mathrm{Ascorbic}$ Acid-Metavanadate Ion $\}$ Solution in the Presence of PVA at $\mathrm{pH} 6.0$

QnPh: $1.5 \times 10^{-4} \mathrm{~mol} / 1$, metavanadate ion: $5.0 \times 10^{-6} \mathrm{~mol} / 1$, PVA: 0.1 $\%$, L-ascorbic acid: $0.1 \%$, excitation wavelength: $400 \mathrm{~nm}$,

- QnPh-L-ascorbic acid solution,

- - - $\{$ QnPh-L-ascorbic acid-metavanadate ion $\}$ solution.

例として, 両イオン性界面活性剂 AM 301 の併用 下, PR と T.Cl.Fl を組合わせ用い, 痕跡量の $\mathrm{Tl}(\mathrm{I})$ を蛍光定量した! ${ }^{147)}$

$\mathrm{Fl} . \mathrm{Hg}_{4}, \quad$ 2,4-Cl.Fl. $\mathrm{Hg}_{2}, \quad$ 2,7-Cl.Fl. $\mathrm{Hg}_{2}, 3^{\prime}, 4^{\prime}, 5^{\prime}, 6^{\prime}-$ T.Cl.Fl.Hg $, \quad 3^{\prime}, 4^{\prime}, 5^{\prime}, 6^{\prime}$-T.Br.Fl. $\left.\mathrm{Hg}_{4}\right)$ のうち, $3^{\prime}$, 4',5', 6'-T.Cl.Fl.Hg 4 体は安定で, $\mathrm{S}^{2-}$, チ才尿素誘 導体あるいは窒素原子をもつオキシン (Ox), HPC などと赤色に反応し， Ex $365 \mathrm{~nm}, \mathrm{Em} 550$ 又は 555 $\mathrm{nm}$ でチ才尿素 0-19.5 $\mu \mathrm{g} / 10 \mathrm{ml}, \mathrm{HPC} 0.15-1.0 \mu \mathrm{g}$ $/ 10 \mathrm{ml}, 0-40 \mu \mathrm{g} / 10 \mathrm{ml} \mathrm{S}{ }^{2-}, 0-20 \mu \mathrm{g} / 10 \mathrm{ml} \mathrm{Ox}$ の蛍 光定量に応用した. ${ }^{34,47)}$ 同じように, マーキュロク ロムは, 硫黄原子をもつ $\beta$-ラクタム系ペニシリン 誘導体と消光反応し, その蛍光強度とペニシリン誘 導体との間に指数曲線的な検量線が成立した。 また, $\beta$ - ラクタム系医薬品の活性（ディスク法の抑制值） と消光性 $(\Delta \mathrm{F}$ 值 $)$ との関連追求に良好で, $\beta$-ラク 夕ム系抗生物質の分析と活性度検索に有効であった …抗生物質の検出限界值, AB-PC で $0.8 \mu \mathrm{g} / \mathrm{ml}$, 検
Table 6. Effect of Surfactants on the Fluorescence Reactions between QnPh and Vanadium

\begin{tabular}{cccl|cc}
\hline \hline Catio & Anionic & Amphoter & \multicolumn{1}{c|}{ Nonion } & $\lambda_{\max }$ & \multicolumn{1}{c}{$\Delta \mathrm{F} \%$} \\
\hline- & - & - & - & 540 & 52.6 \\
HTAC & - & - & - & 545 & 48.4 \\
- & SDS & - & - & 540 & 53.1 \\
- & - & LS & - & 535 & 42.4 \\
- & - & - & PVA & 540 & 54.4 \\
& & & (n=1900 & & \\
- & - & - & (n=500) & 540 & 52.9 \\
- & - & - & Tween 20 & 535 & 46.4 \\
- & - & - & Brij 35 & 540 & 52.5 \\
- & - & - & Triton X 100 & 540 & 52.6 \\
- & - & - & PVP & 540 & 48.6 \\
- & - & - & MC & 540 & 52.0 \\
\hline
\end{tabular}

$\mathrm{V}(\mathrm{V}): 5.0 \times 10^{-7} \mathrm{~mol} / \mathrm{l}$, QnPh: $1.5 \times 10^{-4} \mathrm{~mol} / \mathrm{l}$, L-ascorbic acid $0.1 \%$, pH 6.0 , surfactant $0.2 \%$.

Table 7. Detection Tests of Penicillins and Cepham Antibiotics with Mercurochrome (0.1\%)

\begin{tabular}{c|ccc}
\hline \hline$\beta$-antibiotic & Sample & Blank & Detection limit $(\mu \mathrm{g} / \mathrm{ml})$ \\
\hline Amoxicillin & or Rd & Or & 0.8 \\
Penicillin-G & or Rd & Or & 1.0 \\
Ampicillin & or Rd & Or & 1.0 \\
Sulbebicillin & or Rd & Or & 1.5 \\
Cephalexine & or Rd & Or & 1.5 \\
\hline
\end{tabular}

量線生成域— $50 \mu \mathrm{g} / 10 \mathrm{ml}$ ペニシリン類, 一60 $-6 \mathrm{~g}$ / $10 \mathrm{ml}$ セファム系抗生物質で, イミダゾール $-\mathrm{Hg}$ 法 の約 6 倍の鋭敏度を示した。なお，本法により，全 $\beta$ - ラクタム系抗生物質とその分解物質との相互分 析も可能であった. すなわち, $60^{\circ} \mathrm{C}, 45$ 分間の加熱 操作によって全 $\beta$ - ラクタム系抗生物質量の定量 が, また室温下での反応操作によって分解物質量の 分析が行われた (Table 7)..117)

2-2. アゾ系試薬, 芳香族アミン系誘導体の利用 アゾ系水溶性色素のPAR が, 陽イオン性界面活性 剂併用下の $\mathrm{Fe}(\mathrm{III}),{ }^{122)} \mathrm{Hg}(\mathrm{II}),{ }^{111)} \mathrm{U}(\mathrm{VI}),{ }^{154)}$ Dy (III), 139) Os (III), 137) $\mathrm{Zr}(\mathrm{IV}), \mathrm{Hf}(\mathrm{III})^{87)}$ などの $\{\mathrm{M}\}$ 発色反応に活用でき, その際, 界面活性剂の 併用は呈色の安定性及び再現性の点において効果を 示した。特に, PAR-Hg(II) ${ }^{111)}$ の応は, PAR : $\mathrm{Hg}(\mathrm{II}): \mathrm{HPC}=3: 2: 2$ の会合体で, HPC のない 場合のほぼ 1.6 倍值で, $\mathrm{Fe}$ (III) 及び $\mathrm{Al}$ (III) との相 互分離も HPC の併用により可能なことを見出し 
た。さらに，組合わせ界面活性剂併用効果例として， HTAC あるいは HPC と非イオン性の Brij 58 ある いは Triton X-305 共存が \{PAR-Os (VIII)\} \{PARDy (III) \} の反応 ${ }^{137,139)}$ に，また，両イオン性の LSBrij の併用は，PAR-Ce (III) ${ }^{87)}$ 間の呈色の安定性, 感度の上昇に有効であった。一方，アゾ系 $\{\mathrm{R}\}$ の Zincon-Ni (II) , ${ }^{88)}-\mathrm{Ga}(\mathrm{III})^{80)}$ 間への陽イオン性界面 活性剂の併用効果はなく, 錯体の安定化のみの効果 を示した。

\section{3. 有機試薬と金属イオン $\{\mathbf{R}\}-\{\mathbf{M}\}$ 反応への接 触作用}

キサンテン系，芳香族アミン系試薬 $\{\mathrm{R}\}$ が，過 酸化水素 $\left(\mathrm{H}_{2} \mathrm{O}_{2}\right)$, 亜硝酸 $\left(\mathrm{NO}_{2}^{-}\right)$, バナジン酸, 過 硫酸 $\left(\mathrm{S}_{2} \mathrm{O}_{8}^{2-}\right)$ などと共存する $\mathrm{Co}(\mathrm{II}), \mathrm{Fe}(\mathrm{III}), \mathrm{Ni}$ (II), $\mathrm{V}(\mathrm{V}), \mathrm{Pb}(\mathrm{II})$ 量に比例する接触的作用より, これら $\{\mathrm{M}\}$ 及び $\mathrm{H}_{2} \mathrm{O}_{2}, \mathrm{NO}_{2}^{-}$などの痕跡量が蛍光 あるいは吸光定量できた。

3-1. キサンテン系誘導体 $\{\mathrm{R}\}$ - $\{\mathrm{M}\}$ 間の反 応を用いる $\{\mathrm{M}\}$ 定量において，第三物質 $\{\mathrm{Org}\}$ の共存による新たな会合体の生成, あるいは新たな 競合反応 (分解反応), さらには $\{\mathrm{R}-\mathrm{M}\}$ 錯体形成 への $\{\mathrm{Org}\}$ の接触的作用などが観察された. すな わち，\{R\}-Sn(IV) 間反応へのシュウ酸 $\left(\mathrm{C}_{2} \mathrm{O}_{4}^{2-}\right)$ の接触効果が, Gall-Sn (IV), Phfl-Sn (IV) ${ }^{25,29)}$ 間で, Ox の共存効果が MTB-Zn (II), MTB-Cd (II) ,50) Cl.Gall. $\mathrm{CH}_{3}$ - $\mathrm{Ce}(\mathrm{III})^{44)}$ 間に, Phen の併用効果が Cl.Gall. $\mathrm{CH}_{3}-\mathrm{Pb}$ (II) 反応 ${ }^{44)}$ に, 希土類元素の $\mathrm{La}$ (III) の共存効果が T.Cl.Gall-Th (IV) 間の反応 ${ }^{55)}$ に，また $\mathrm{F}^{-}$の共存効果が $\mathrm{Zr}(\mathrm{IV})-\mathrm{XO},{ }^{108)} \mathrm{Zr}(\mathrm{IV})$ Cl.Gall. $\mathrm{CH}_{3},{ }^{27)} \mathrm{Zr}(\mathrm{IV})$-Gall, ${ }^{23)} \mathrm{Zr}(\mathrm{IV})$-QnPh, ${ }^{87)} \mathrm{Zr}$ (IV) - $\mathrm{Phfl}^{32)}$ 間に認められ，これら接触的作用を活 用した各 $\{\mathrm{M}\}, \mathrm{F}^{-}, \mathrm{C}_{2} \mathrm{O}_{4}^{2-}$ などが定量された。な お, この際, 陽イオン性界面活性剂の併用効果も顕 著に観察された。さらに，酸化剂の $\mathrm{H}_{2} \mathrm{O}_{2}, \mathrm{~S}_{2} \mathrm{O}_{8}^{2-}$ などを併用した $\{\mathrm{R}\}$ の分解反応に対する $\{\mathrm{M}\}$ の 接触作用の活用例として, Gall-Mo (VI) ${ }^{48)} \mathrm{QnPh}$ Co (II), ${ }^{107)}$ QnPh-Ti(IV), ${ }^{84)}$ Gall-Fe(III), ${ }^{115)}$ Gall-V (V)，Cl.Gall. $\mathrm{CH}_{3}-\mathrm{Bi}(\mathrm{III})^{15)}$ 間の反応活用の $\{\mathrm{M}\}$ の接触的定量法も確立された. Table 8 に, QnPh と $\mathrm{H}_{2} \mathrm{O}_{2}$ を用いる $\mathrm{Co}(\mathrm{II})$ の吸光光度定量における HTAC と Triton X の組み合わせ界面活性剂の併用 効果を示す。ささらに，\{(R-M)\}間反応で $\{\mathrm{M}\}$ と 反応しやすいイオンの分析例として, $\left\{\right.$ Cl.Gall. $\mathrm{CH}_{3}$
Table 8. Effect of Surfactants on the Determination of Co (II) Using QnPh and Hydrogen Peroxide

\begin{tabular}{|c|c|c|c|c|}
\hline \multirow{2}{*}{$\begin{array}{l}\text { Cationic } \\
-\end{array}$} & \multirow{2}{*}{$\begin{array}{c}\text { Surfactants } \\
\text { Nonionic }\end{array}$} & \multirow{2}{*}{$\frac{\text { Anionic }}{-}$} & \multicolumn{2}{|c|}{$\begin{array}{c}\text { Absorbance at } \\
\lambda_{\max }(\mathrm{nm})\end{array}$} \\
\hline & & & 500 & 0.297 \\
\hline HTAC & - & - & 510 & 0.378 \\
\hline HPC & - & - & 510 & 0.164 \\
\hline $\mathrm{Zp}$ & - & - & 510 & 0.182 \\
\hline- & Brij 35 & - & 500 & 0.103 \\
\hline- & Tween 20 & - & 500 & 0.065 \\
\hline- & Triton X100 & - & 500 & 0.127 \\
\hline - & PVA & - & 500 & 0.060 \\
\hline- & PVP & - & 500 & 0.100 \\
\hline- & - & SLS & 500 & 0.119 \\
\hline HTAC & Brij 35 & - & 510 & 0.315 \\
\hline HTAC & Tween 20 & - & 510 & 0.164 \\
\hline HTAC & Triton X100 & - & 510 & 0.418 \\
\hline $\mathrm{Zp}$ & Triton X100 & - & 510 & 0.340 \\
\hline HTAC & - & SLS & ppt & \\
\hline $\begin{array}{l}\text { HTAC } \\
+\mathrm{Zp}\end{array}$ & - & - & 510 & 0.172 \\
\hline - & $\begin{array}{l}\text { Triton X100 } \\
\text { + Tween } 20\end{array}$ & - & 500 & 0.086 \\
\hline- & $\begin{array}{l}\text { Triton X100 } \\
+ \text { Brij } 35\end{array}$ & & 500 & 0.141 \\
\hline - & Triton X100 & SLS & 500 & 0.121 \\
\hline
\end{tabular}

Co(II) taken: $1.0 \times 10^{-9} \mathrm{~mol} / 1$, QnPh: $7.5 \times 10^{-5} \mathrm{~mol} / 1$, nonionic and anionic surfactants: $0.1 \%$, cationic surfactants: $1.0 \times 10^{-3} \mathrm{~mol} / 1, \mathrm{pH} 10.3$, $\mathrm{H}_{2} \mathrm{O}_{2}: 0.015 \%$, reference: water.

- $\mathrm{Ag}(\mathrm{I})$-Phen\} による $\mathrm{CN}^{-}, \mathrm{S}_{2} \mathrm{O}_{3}^{2-}, \mathrm{I}^{-}$の定量など, 錯体の競合あるいは抑制反応を活用したこれら陰イ オン定量法も開発された. ${ }^{35)}$ 一方, 蛍光の活用例と して, 弱い蛍光性を示す $\mathrm{QnPh}$, 及び発色性を示さ ない Gall 還元体 (ガリイン, Gall.H), 蛍光性のな い $\mathrm{Fl} . \mathrm{NHNH}_{2}$ などのキサンテン系色素 $\{\mathrm{R}\}$ 活用の 金属及び非金属イオン $\{\mathrm{M}\}$ の微量定量法も確立さ れた. $110,118,162)$

3-2. 芳香族アミン誘導体無蛍光性のキノリ ルアニリン誘導体の蛍光性物質転換反応における $\{\mathrm{M}\}$ の促進効果を活用した $\{\mathrm{M}\}$ あるいは非金属 イオンの超微量定量法として, N,N- ジメチル P- フ エニレンジアミン (DPD) を用いる 0-300 ng/10 $\mathrm{ml} \mathrm{Au}(\mathrm{III})$ 定量が auranofin, aurochinmalate など $\mathrm{Au}$ 含有製剂の分析に, ${ }^{158)}$ また, N-エチル -2-ナフ チルアミン（NENA） とベンゾイル過安息香酸 (BPO) と $\mathrm{Cu}(\mathrm{II})$ 間反応が $\mathrm{Cu}(\mathrm{II}), \mathrm{BPO}$ の吸光光 度定量に応用できた。特に，FIA の活用により 0.5

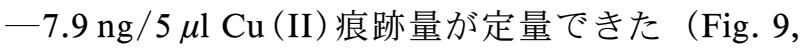


10). 150) なお，この NENA はグルクロン酸 $(\mathrm{Gl})$ の 新規高感度な蛍光光度定量にも適用できた。 ${ }^{145)} \mathrm{N}$ (4'- ヒドロキシフェニル) N-(4-メチルキノリール) アミン (HPMQ) , 4(4-メチル 2-キノリル) アミノ サリチル酸 (MQAS), P-ヒドロキシ 2-アニリノピ リジン（HAP）などが陽イオン性界面活性剤トリ メチルステアリルアンモニウム塩 (STAC) 共存下, $\mathrm{H}_{2} \mathrm{O}_{2}$ あるいは $\mathrm{Co}$ ( II) の蛍光定量に用いられ た. ${ }^{123,127,132,140)}$ さらに, $\{\mathrm{R}-\mathrm{M}\}$ 錯体への共存イオ ンとの競合反応例として, $\{\mathrm{PAR}-\mathrm{Hg}(\mathrm{II})\}$ と $\left.\mathrm{CN}^{-},{ }^{111}\right)\{\mathrm{PAR}-\mathrm{Zr}(\mathrm{IV})\}$ と $\mathrm{F}^{-87)}$ 反応も検討され た.

\section{有機試薬 $\{\mathbf{R}\}$-金属イオン $\{\mathbf{M}\}$ と医薬品, 生体成} 分 $\{$ Org $\}$ 間の反応

従来, 医薬品, 生体成分など有機化合物 $\{\mathrm{Org}\}$ の分析法として, Th(IV), Zr (IV), Mo(VI), Pd(II) などの $\{\mathrm{M}\}$ ，あるいは有機試薬 $\{\mathrm{R}\}$ 単独を用いる $\{\mathrm{M}-\mathrm{Org}\}$ 反応, あるいは $\{\mathrm{R}-\mathrm{Org}\}$ 反応などが活 用されてきたが, これら方法は, 簡便性, 再現性, 感度, 選択性に欠け, より優れた分析法の開発が要 望されている. (1) $\{\mathrm{R}\}$ と $\{\mathrm{M}\}$ 間の反応で, 主に 陽イオン性界面活性剂共存ミセル下における $\{\mathrm{R}\}$ と $\{\mathrm{M}\}$ 間の新たな高次錯体形成を活用した数多く の $\{\mathbf{M}\}$ 分析法を提唱してきた. この $\{\mathbf{R}\}$ と $\{\mathbf{M}\}$ 間の反応に際し，陽イオン性界面活性剂に代わる有 機化合物の分析対象物質 $\{\mathrm{Org}\}$, 並びにその他界 面活性剂（分散剂）の併用は, (1) $\{(\mathrm{R}-\mathrm{M})\}$ 二元錯 体と別の高次錯体を生成して感度, 安定性の増大, (2) $\{(\mathrm{R}-\mathrm{M})-\mathrm{Org}\}$ 高次錯体生成の活用は, 従来の $\{\mathrm{R}-\mathrm{Org}\}$ あるいは $\{\mathrm{M}-\mathrm{Org}\}$ 二元錯体生成を活用 する $\{\mathrm{Org}\}$ 定量と相違して, $\{(\mathrm{R}-\mathrm{M})\}$ 二元錯体 に対する $\{\mathrm{Org}\}$ の反応性を活用することより， $\{\mathrm{Org}\}$ への選択性, 特異性の発現, (3) $\{\mathrm{Org}\}$ 共存 による $\{\mathrm{R}-\mathrm{Org}\}$ あるいは $\{\mathrm{M}-\mathrm{Org}\}$ の競合的反応 などによる選択性, 感度, (4)界面活性剂の併用によ る $\{(\mathrm{R}-\mathrm{M})-\mathrm{Org}\}$ 高次錯体のミセル界面への取込 み, 濃縮効果による感度, 安定性, (5) $\{(\mathrm{R}-\mathrm{M})-\mathrm{Org}\}$ 錯体の界面活性剂併用によるミセル形成による抽出 操作の省略などの利点が期待される. もちろん, こ の三元錯体の生成あるいは競合的二元錯体の生成反 応が起こり得るか否かは, 使用する $\{\mathrm{R}\}$ あるいは $\{\mathrm{Org}\}$ の錯生成基の性質, 使用する $\{\mathrm{M}\}$ の特性, すなわち配位基の塩基性, $\{\mathrm{M}\}$ の電荷, イオン半

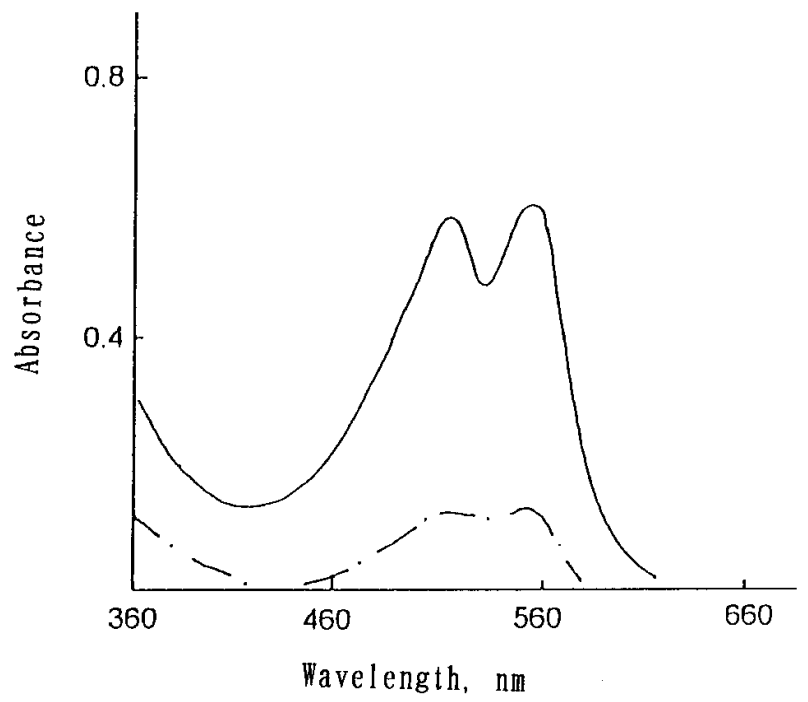

Fig. 9. Absorption Spectra of DPD-Potassium Persulfate and $\{$ DPD-Potassium Persulfate-Au (III) $\}$ Solutions at pH 4 DPD: $1.0 \times 10^{-3} \mathrm{~mol} / \mathrm{l}$, potassium persulfate: $1.0 \times 10^{-4} \mathrm{~mol} / \mathrm{l}$, Au (III) : $700 \mathrm{ng} / 10 \mathrm{ml}$, reference: water.

- - - : DPD-potassium persulfate solution, : $\{$ DPD-potassium persulfate-Au(III) $\}$ solution.

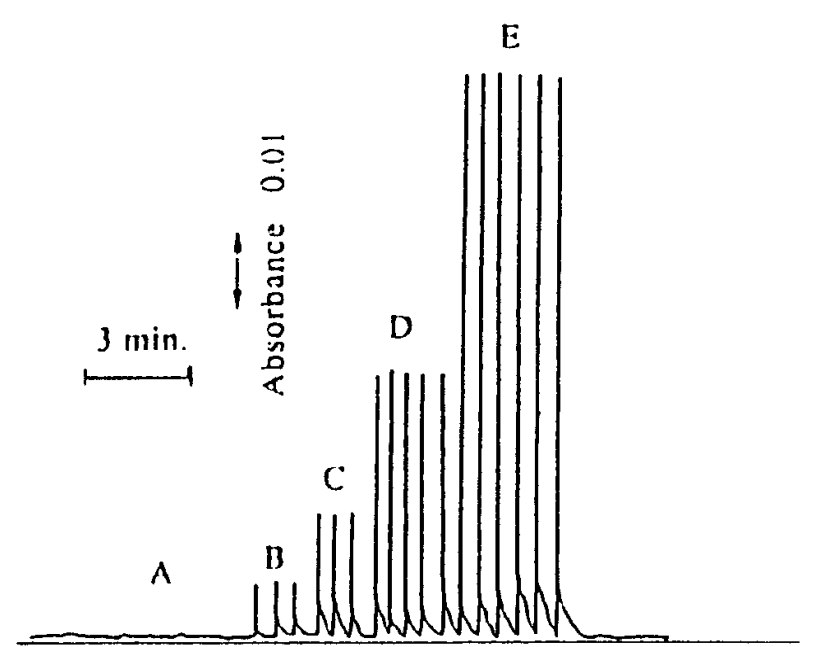

Fig. 10. Calibration Peak Signal for Determination of $\mathrm{Cu}$ (II) on FIA

(NENA-BPO) : $5.0 \times 10^{-4} \mathrm{~mol} / \mathrm{l}$, flow rate of (NENA-BPO) solution $1.6 \mathrm{ml} / \mathrm{min}$, flow rate of buffer solution $(\mathrm{pH} 5.0) 0.8 \mathrm{ml} / \mathrm{min}, \mathrm{Cu}$ (II) concentrations $\cdots$ curve A: $0 \mathrm{ng}$, curve B: $0.50 \mathrm{ng}$, curve C: $0.99 \mathrm{ng}$, curve D: $1.99 \mathrm{ng}$, curve E: $3.97 \mathrm{ng}$.

径, 配位数, 電子配置, 生成錯体の大きさとその構 造などにより異なってくる. したがって，どのよう な反応系が生成するかを予測することは, 不可能で あるが, \{Org\} の構造, 錯生成能, HSAB 則, Irving-Williams 序列などより，ある程度， $\{\mathrm{M}\}$ 及び $\{\mathrm{R}\}$ を選択し， $\{\mathrm{Org}\}$ の選択的，高感度な吸光あ るいは蛍光定量法を確立することが可能である．こ 
れら事実より，\{Org\} に対するキサンテン系色素 $\{\mathrm{R}\}$ ，多原子価 $\{\mathrm{M}\}$ 及び各種界面活性剂などの適 宜組み合わせを検討のうえ，目的とするパパベリ ン，キニーネ，ペニシリン，テトラサイクリン，ウ ラシル，アルブミン (HSD) などを始めとする $\{\mathrm{Org}\}$ の高感度, 簡便, 迅速, 選択的な定量法が, 以下のように確立された。

\section{1. 有機試薬-金属イオン $\{\mathbf{R}-\mathbf{M}\}$ 錯体一分析対象 物質 $\{$ Org $\}$ 間の反応}

血漿タンパク質は, 腎臟などの疾患で病的タンパ ク量として増大することより, 尿タンパク質量の追 跡が, 臨床検查上必要不可欠となっている。一般 に，タンパク質は種々の $\{\mathrm{M}\}$ あるいは $\{\mathrm{R}\}$ と反 応し易く, $\mathrm{CPB}$, ブロモクレゾールグリーン (BCG)，ブロモフェノールブルー(BPB) あるいは Eosinなどのフタレイン系色素とメタクロマジー現 象を示す。従来, 尿タンパク分析法として, スルホ サリチル酸を用いる Kingsbury-Clark 法, クマシー ブリリアントブルー $(\mathrm{CPB})$ などを用いる色素結合 法などが利用されてきているが, 操作複雑でバラッ キも大きいなどの欠点を有する。したがって，その 改良を目的に, より簡便, 迅速, 選択的で高感度な タンパク質分析法の開発に $\{(\mathrm{R}-\mathrm{M})\}$ 錯体の活用 を試みた。

1-1. 会合体生成の活用各種界面活性剂共存 下， $\{\mathbf{R}\}$ と $\{\mathbf{M}\}$ 間の反応を活用した(1)の $\{\mathbf{M}\}$ 定量法において, 第 4 級アンモニウム塩型陽イオン 界面活性剂の共存は，\{R\} にキサンテン系色素を，

$\{\mathrm{M}\}$ に多価金属イオンを選択する際，極めて有効 であった。一般に，タンパク質は分子中に極性及び 非極性部をもつ高分子化合物で, 陽イオン性界面活 性剂と類似の挙動を示すと推測されることより，

$\{\mathrm{R}\}$ - 多価 $\{\mathrm{M}\}$ 錯体とタンパク質を反応させた場 合，同様の結合反応によるスペクトル上の変化が考 えられる。したがって，キサンテン系色素 $\{(\mathrm{R}-\mathrm{M})\}$ 間錯体とタンパク質との間の反応を活用 するタンパク質定量法の開発について種々検索し た。 まず $\{\mathrm{M}\}$ として，共存イオンの影響が少ない 酸性領域下において, $\{\mathrm{R}\}$ と $\{\mathrm{M}\}$ 間の反応が進 行しやすい Mo(VI), Sn(IV), Ti(IV), Mn(II)など の多原子価金属イオンを $\{\mathrm{M}\}$ として選択のうえ, $\{\mathrm{R}\}$ の有用性を検索したところ, BCG 類似構造を 有する PR, QnPh, Sul.Phfl, T.Cl.Qnph, $\mathrm{COOH}$.
QnPh などが有効であった。すなわち，分散剂を併 用した pH 2.5 付近の強酸性下，ヒト血清アルブミ ン(HSA）添加した $\{(\mathrm{PR}-\mathrm{Mo}(\mathrm{VI}))-\mathrm{HSA}\}$ 液は, ブランクの $\{(\mathrm{PR}-\mathrm{Mo}(\mathrm{VI}))\}$ 液との吸収スペクト ル差 $(600 \mathrm{~nm})$ が著明な事実より, HSA の新規吸 光定量法として $\{(\mathrm{PR}-\mathrm{Mo}(\mathrm{VI}))-\mathrm{HSA}\}$ 法が提唱さ れた. ${ }^{68)}$ 本法は, (1)従来法に比して高感度で, (2)夕 ンパク質の種類の相違による反応差はない, (3)生体 成分や投与薬剂などによる共存成分の干渉が少ない, (4)検量線範囲が広い，(5)測定セルへの $\{\mathrm{R}-\mathrm{M}$ - 蛋白 質）会合体の吸着が少ない, (6)従来法に比して再現 性, 安定性に優れるなどの利点より, 本 $\{\mathrm{PR}-\mathrm{Mo}$ （VI）？法は, 総タンパク質定量用キット（Micro TP-Test Wako) として活用された。 タンパク質は, 等電点（pI, HSA で 4.2-4.8）以下で，カチオン型 として存在することより， $\{\mathrm{R}\}$ と $\{\mathrm{M}\}$ との反応 を用いる際の感度, 選択性は, $\{\mathrm{R}\},\{\mathrm{M}\}$ あるいは 分散剤などの種類に依存すると考えられる。すなわ ち, $\mathrm{HSA}$ 定量に際し， $\{\mathrm{R}\}$ として $\mathrm{SO}_{3} \mathrm{H}$ 基を有し, 比較的酸性域下，陽イオン性界面活性剂共存下での $\{\mathrm{M}\}$ との反応の使用により，より高感度な HSA 定量法の確立を予測した。 $\{\mathrm{R}-\mathrm{M}\}$ 錯体活用の本反 応系も，錯体の色素部分との相互作用であり，一時 的にタンパク質の正電荷部位とキサンテン系誘導体 である酸性色素の陰電荷部位との静電相互作用,

$\{\mathrm{R}\}$ の疎水性部位である芳香環部と HSA の疎水性 部位の炭化水素側鎖部との相互作用, すなわち, 疎 水性相互作用と推測した。なお， $\{\mathrm{R}\}$ として Gall, 2,7- ジ Cl.Gall (Cl.Gall), 2,7- ジ Br.Gall (Br.Gall), T.Cl.Gall と T.Br.Gall, 2,7- ジ Br.QnPh (Br.QnPh), $\mathrm{COOH} . \mathrm{QnPh}$, Sul.Phfl などのキサンテン系試薬 $\{$ R $\}$ と HSA との呈色反応の検討において，用いる $\{\mathrm{R}\}$ のフルオラン環への $\mathrm{X}$ 基導入の効果は観察さ れなかった。一方, $\{\mathrm{M}\}$ として $\mathrm{Mo}(\mathrm{VI})$ の外, $\mathrm{W}$ (VI), U (VI), $\mathrm{Al}(\mathrm{III}), \mathrm{Fe}(\mathrm{III})$ などの多原子価 $\{\mathrm{M}\}$ の使用が有効で, 特に, \{T.Cl.Gall-Mo(VI) （Triton $\mathrm{X}$ 405)\} の組合わせが最適であった. Table 9 に，共同研究者の藤田助教授を中心に行われたタン パク質定量法を， $\{\mathrm{R}\},\{\mathrm{M}\}$ 及び分散剤の組み合わ せとして一括表示する (Fig. 11), (Table 10).

メジャートランキライザーであるフェノチアジン 誘導体のクロルプロマジンと陰イオン性界面活性剂 の $\mathrm{SDS}$ 共存下の $\left\{(\mathrm{QnPh})_{2}-\mathrm{Pd}(\mathrm{II})_{2}\right.$ (Chlorproma- 
Table 9. The Assay of Protein by $\{\mathbf{R}\}-\{\mathbf{M}\}$ Complexes

\begin{tabular}{|c|c|c|c|c|c|}
\hline$\{\mathbf{R}\}$ & $\mathrm{pH}$ & $\{\mathbf{M}\}$ & & Calibration & \\
\hline \multirow[t]{2}{*}{ PR } & & & $\operatorname{Mo}(\mathrm{VI})$ & & 68) \\
\hline & $1.5-5.0$ & gum & $600 \mathrm{~nm}$ & $0-400 \mu \mathrm{g}$ & \\
\hline \multirow[t]{2}{*}{ PV } & & & $\operatorname{Mo}(\mathrm{VI})$ & & 75) \\
\hline & $2.5-3.0$ & PVA & 680 & $0-300$ & \\
\hline \multirow[t]{4}{*}{ PV } & & & $\mathrm{Sn}(\mathrm{IV})$ & & 155) \\
\hline & $1.4-2.1$ & gum + Triton & 645 & $0-200$ & \\
\hline & & & & MF method & \\
\hline & & CPC & 660 & $0-60$ & \\
\hline \multirow[t]{5}{*}{ Sul. Phfl } & & & $\mathrm{Ti}(\mathrm{IV})$ & & 135) \\
\hline & $1.7-2.7$ & Triton PVA & 585 & $0-300$ & \\
\hline & & Triton PVP & 590 & $5-200$ & 159) \\
\hline & & & $\mathrm{U}(\mathrm{VI})$ & & 124) \\
\hline & $3.2-4.2$ & Triton & 555 & $0-500$ & \\
\hline \multirow[t]{2}{*}{ T. Cl. Gal } & & & $\operatorname{Mo}(\mathrm{VI})$ & third deriv. & 120) \\
\hline & $2.2-3.5$ & Triton PVA & 640 & $0-150$ & \\
\hline \multirow[t]{3}{*}{ T. Cl. Phfl } & & & $\operatorname{Mn}(\mathrm{II})$ & & 143) \\
\hline & $9.2-9.8$ & PVP & 590 & $0-200$ & \\
\hline & & (T. Cl. QnPh) & $\operatorname{Mn}(\mathrm{II})$ & basic proteins & \\
\hline \multirow[t]{2}{*}{$\mathrm{CR}-\mathrm{B}$} & & & $\mathrm{Be}(\mathrm{II})$ & FIA method & 138) \\
\hline & $4.2-4.9$ & Triton & 625 & $0-150$ & \\
\hline \multirow[t]{2}{*}{ 5-Br. PAPS } & & & $\mathrm{Co}(\mathrm{II})$ & & 151) \\
\hline & $1.5-2.0$ & PVP & 636 & $0-70$ & \\
\hline
\end{tabular}

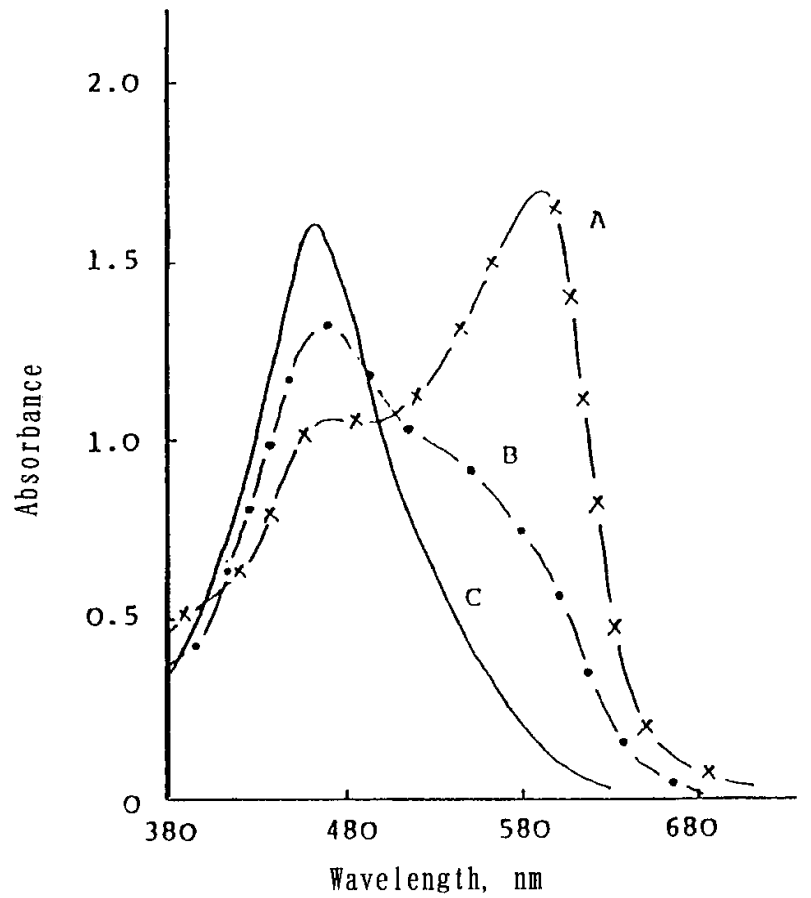

Fig. 11. Absorption Spectra of PR, PR-Albumin, $\{P R-M o$ (VI) $\}$ and $\{\mathrm{PR}-\mathrm{Mo}$ (VI)-Albumin $\}$ Solutions at $\mathrm{pH} 2.5$

PR: $1.0 \times 10^{-5} \mathrm{~mol} / \mathrm{l}, \mathrm{Mo}(\mathrm{VI}): 5.0 \times 10^{-5} \mathrm{~mol} / \mathrm{l}$, albumin: $500 \mathrm{ng} / 10$ $\mathrm{ml}$, gum arabic: $0.2 \%$, reference: water.

Curve A: \{PR-Mo (VI)-albumin\} solution, Curve B: $\{$ PR-Mo (VI) $\}$ solution, Curve C: PR or PR-albumin solution.
Table 10. Reaction between Several Proteins and \{Suf. PhflTi(IV)\} Complex

\begin{tabular}{lc}
\hline \hline \multicolumn{1}{c}{ Proteins } & $\begin{array}{c}\text { Absorbance at 585 } \mathrm{nm} \\
(\%)\end{array}$ \\
\hline HSA & $0.510(100.0)$ \\
BSA & $0.515(101.0)$ \\
$\gamma$-Globulin (Human) & $0.323(63.3)$ \\
$\beta$-Globurin (Human) & $0.321(62.9)$ \\
Hemoglobin (Human) & $0.516(101.2)$ \\
Cytochrome C (Horse) & $0.529(103.7)$ \\
Transferrin (Human) & $0.484(94.9)$ \\
Haptoglobin (Human) & $0.525(102.9)$ \\
$\alpha$-Chymotrypsinogen-A (Bovine) & $0.529(103.7)$ \\
BSA, Glycated & $0.542(106.3)$ \\
BSA, Methylated & $0.522(102.4)$
\end{tabular}

Protein taken: $100 \mu \mathrm{g} / 10 \mathrm{ml}$ (uncorrected) (\%) Percent with respect to HSA.

zine $\left.)_{2}\right\}$ 錯体の吸光度より $0-150 \mu \mathrm{g}$ Chlorpromazine が, 61) \{クロムアズロール S (CRS) -Be(II) \} 錯 体によるフェノチアジン系のクロルプロマジン, チ オキサンテン系のクロルブロチキセンなどと一 1.5 $\times 10^{-5} \mathrm{M}$ 濃度範囲 $\left(\varepsilon=(5-11) \times 10^{4}\right)$ の定量法が 開発された。 ${ }^{144)}$ 同じように，骨格筋驰緩薬である 
ツボクラリンも, 陰イオン性界面活性剂の SDS 存 在下の $\left\{\left(\mathrm{ZrF}_{4}\right)(\mathrm{QnPh})_{2}\right\}$ 錯体で, ${ }^{69)}\left\{(\mathrm{QnPh})_{2}\right.$ $\left.\left(\mathrm{UO}_{2}\right)(\text { Reserpin })_{2}\right\}$ 錯体を用い $5-10 \mu \mathrm{g} / 10 \mathrm{ml}$ 血 管中枢抑制剤のレセルピンも定量された. ${ }^{76)}$ 抗ヒス タミン剂フェノチアジン誘導体のマレイン酸クロル フェニラミン $(\mathrm{CPM})$ も， $\{\mathrm{QnPh}-\mathrm{Ti}(\mathrm{IV})\}$ 錯体の $\mathrm{CPM}$ 共存に伴う吸光度増加で, $0-45 \mu \mathrm{g} / 10 \mathrm{ml}$ CPM 量をエフェドリンの妨害なく定量できた。 ${ }^{67)}$ また, $\{\mathrm{BPR}-\mathrm{Nb}(\mathrm{V})\}$ 錯体を Tween 20 共存下に活 用して CPM が定量された. ${ }^{167)}$

\section{1-2. 競合反応の活用 $\{\mathrm{R}-\mathrm{M}\}$ 錯体への $\{\mathrm{Org}\}$} による競合反応の活用例として，\{QnPh-Ce (IV) $\}$

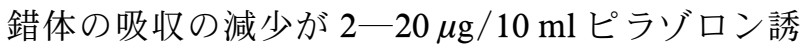
導体のスルピリンに, また 3,5-ピラゾリジンジオ ン誘導体のフェニルブタゾンも同じように定量でき た. ${ }^{77)}\{(\mathrm{QnPh}-\mathrm{Pd}(\mathrm{II}))-\mathrm{HTAC}\}$ 錯体のセファレキ シン, アンピシリン，イソニアジド間の吸光度減少 が，セファレキシン，アンピシリン，イソニアジド の定量 ${ }^{58,62)}$ に，また，慢性副鼻炎症治療剤の塩化リ ゾチームに $\{\mathrm{Sul} . \mathrm{Phfl}-\mathrm{Ti}(\mathrm{IV})\}$ 錯体生成反応が 0$200 \mu \mathrm{g} / 10 \mathrm{ml}$ の定量に利用された. ${ }^{161)}$ グアニジン系 殺菌薬の塩酸クロルヘキシジン $(\mathrm{CH})$, グルコン酸 クロルヘキシジンの定量が， $\{\mathrm{QnPh}-\mathrm{Mn}(\mathrm{II})\}$ 錯体 を用い $0-50.6 \mu \mathrm{g} / 10 \mathrm{ml} \mathrm{CH}$ 定量 ${ }^{126)}(\Delta \mathrm{G}=-5.49$ Kcal $\mathrm{mol}^{-1}, \Delta \mathrm{H}=0.04 \mathrm{Kcal}^{\mathrm{mol}}{ }^{-1}, \Delta \mathrm{S}=18.60 \mathrm{cal}$ $\left.\mathrm{mol}^{-1} \mathrm{~K}^{-1}\right),\{\mathrm{QnPh}-\mathrm{Fe}(\mathrm{III})\}$ 錯体が, 各種クェン 酸含有食物の分析に応用された（Table 11）. ${ }^{98)}$ そ の他, 競合反応（抑制）応用例として, \{Sulf.Phfl$\mathrm{Ti}(\mathrm{IV})\}$ 錯体の $\mathrm{H}_{2} \mathrm{O}_{2}$ 共存による退色反応を用いる
$\mathrm{H}_{2} \mathrm{O}_{2}$ 定量は, 従来の混合錯体法のほぼ 4-10 倍の 鋭敏度 $\left(\varepsilon=2.3 \times 10^{5}\right)$ で, ${ }^{89)}$ さらに, $\{\mathrm{QnPh}-\mathrm{Ti}(\mathrm{IV})$ EDTA $\}$ 錯体を HTAC 共存下に用いて $0.02-2 \mu \mathrm{g}$ / $10 \mathrm{ml} \mathrm{H}_{2} \mathrm{O}_{2}$ の定量, ${ }^{149)}$ Triton $\mathrm{N}-101$ 共存下 の $\left\{(\mathrm{COOH} . \mathrm{Phfl})-\mathrm{Ti}(\mathrm{IV})-\mathrm{H}_{2} \mathrm{O}_{2}\right\}$ 会合体反応が, 1.0 $-6.0 \times 10^{-6} \mathrm{M}$ EDTA の定量に利用された. ${ }^{163)}$

その他, 会合体生成反応あるいは競合反応の活用 例を，併用する界面活性剤の単独使用並びに界面活 性剂組み合わせ別にまとめ, 記載する。

\section{1-3. 界面活性剂の単独使用}

* MC $\cdots$ QnPh-U (VI) -Thiamine, ${ }^{51)}$ QnPh-U (VI) Papave, ${ }^{53)}$ QnPh-U(VI)-Reserp, ${ }^{76)}$ QnPh-U(VI) Quinine, ${ }^{59)}$ QnPh-U(VI)-Neomyc, ${ }^{72)}$ QnPh-U(VI) Toburamy, ${ }^{72)}$ Eosine-Pd(II) -Lincomy, ${ }^{104)}$ Eosine-Pd (II) -Thiamaine, ${ }^{104)}$ Eosine-Pd(II)-Oflax, ${ }^{104)}$ EosinePd (II) -Theophy, ${ }^{104)}$ Eosine-Pd (II) -Chlorproma, ${ }^{104)}$ Br.PAPS-Cu (II)-Album ${ }^{151)}$

* PVA, PVP $\cdots$ T.Cl.Fl-Pd(II)-Papav, ${ }^{82)}$ Eosine-Ga (III)-Minocy, ${ }^{95)}$ QnPh-Mn(II)-Strep, ${ }^{64)}$ Eosine-Ag (I)-Adenin, ${ }^{74)}$ Sul.Phfl-Ti(IV)-Prote, ${ }^{135)}$ QnPh-Mn (II)-Chlolhex, ${ }^{126)}$ QnPh-Mn (II)-HPC, ${ }^{81)} \quad$ T.Cl. QnPh-Mn (II) -Protein ${ }^{143)}$

* Tween $\cdots P R-M o(V I)-Q u i n i n e,{ }^{52)}$ QnPh-Fe(III) Citric, ${ }^{98)} \quad$ BPR-Nb (V)-Chloriphni, ${ }^{167)} \quad$ Sul.Phfl-Fe (III) -Glycyr ${ }^{156)}$

* Gum 又は Briji $35 \cdots$ PR-Mo(VI) -Alubm, ${ }^{68)}$ Phfl$\mathrm{Fe}$ (III) -Norepine $\mathrm{e}^{93)}$

* Triton- $\mathrm{H}_{2} \mathrm{O}_{2} \cdots$ COOH.Phfl-Ti(IV)-EDTA ${ }^{101,163)}$

* Triton-arabic $\cdots$ PV-Sn (IV) -Proteine, ${ }^{159)}$ Sulf.

Table 11. Determination of Citric Acid in Foods

\begin{tabular}{|c|c|c|c|c|c|}
\hline \multirow{2}{*}{ Sample ${ }^{a)}$} & \multicolumn{5}{|c|}{ Citric acid, found (mg) } \\
\hline & Proposed method & PBA $^{b)}$ method & Enzymatic method & Recovery $(\%)^{c)}$ & R. S. D. $(\%)$ \\
\hline Carbonated drink A & 2.65 & 2.33 & 2.45 & 99.9 & 2.0 \\
\hline B & 2.10 & 2.04 & 2.12 & 96.7 & 2.5 \\
\hline Ica candy A & 0.82 & 0.73 & 0.82 & 97.4 & 1.9 \\
\hline B & 1.30 & 0.93 & 1.29 & 103.5 & 4.0 \\
\hline Whiskey & 2.13 & ND & 2.04 & 101.6 & 3.8 \\
\hline Beer & 1.04 & 1.09 & 1.10 & 94.5 & 2.2 \\
\hline Yogurt & 2.44 & 1.87 & 1.99 & 100.9 & 2.9 \\
\hline Tomato & 4.70 & 4.55 & 4.65 & 99.1 & 1.6 \\
\hline Kiwi & 9.80 & 9.65 & 10.06 & 102.4 & 3.2 \\
\hline Lemon & 43.25 & 43.20 & 40.38 & 96.9 & 3.0 \\
\hline
\end{tabular}

a) Carbonated drink: ice candy, beer, yogurt $\mathrm{mg} / \mathrm{ml}$, whisky $\mathrm{mg} / 100 \mathrm{ml}$, tomato, kiwi, lemon $\mathrm{mg} / \mathrm{g}$ b) Pentabromoacetone method c) Citric acid added, $1.9 \mu \mathrm{g} / 10 \mathrm{ml}$. 


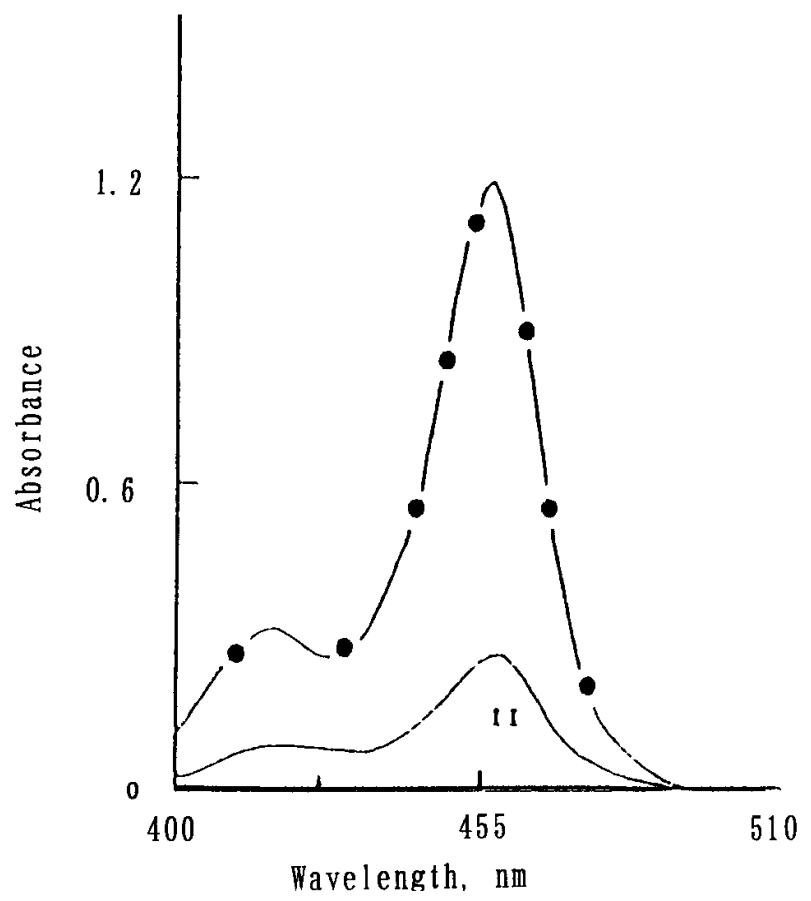

Fig. 12. Absorption Spectra of \{Phloxine-Pd(II)-Thiamnine\} DMSO Solution and Phloxine-Thiamine DMSO Solution after Membrane Filter Preconcentration Technique

Phloxine: $1.5 \times 10^{-5} \mathrm{~mol} / \mathrm{l}$, thiamine: $1.0 \times 10^{-5} \mathrm{~mol} / \mathrm{l}, \mathrm{Pd}(\mathrm{II}): 0.42 \mu \mathrm{g}$, PEG: $0.03 \%$, reference: DMSO.

Curve 1: $\{$ Phloxine-Pd(II)-Thiamnine\} DMSO solution, Curve 2: Phloxine-Thiamine DMSO solution.

Phfl-Ti (IV) -Lysozyme ${ }^{161)}$

\section{1-4. 界面活性剂の組み合わせ}

* Triton-PVA が T.Cl.Gall-Mo ( VI ) -Album, ${ }^{120)}$ Sul.Phfl-Ti (IV)-Albumin, ${ }^{135)}$ Triton が Sul.Phfl-U (VI)-Albumin, ${ }^{124)}$ (Gum PR-Mo (VI)-Albumin $\left.{ }^{68)}\right)$ *カチオン性界面活性剂 (HTAC, HPC, Zp など) の競合反応…QnPh-Pd (II) -Cephalex, Ampici, ${ }^{58)}$ QnPh-Pd (II ) -Thiourea, 57) QnPh-Pd (II) -Iodouracil, ${ }^{65)}$ QnPh-Pd(II)-Isoniazide, ${ }^{62)}$ QnPh-Ce(III)Sulpy, ${ }^{77)}$ Gall-Mo(VI)-Chloramine T, ${ }^{110}$ ) Gall-Sn (IV) -Citric acid, ${ }^{25)}$ Br.QnPh-Al ( III ) -Phenylpyr, ${ }^{79)} \mathrm{NO}_{2}$.PAPS-Nb (III) -Tartaric ${ }^{165)}$

* SDS, SDBS $\cdots$ QnPh-Zr (IV)-Berber, ${ }^{85)}$ QnPh-Zr (IV)-Minocy, 66) QnPh-Zr (IV)-Thiourea, ${ }^{57)}$ QnPhPd (II) -Chlorproma, ${ }^{61)}$ QnPh-Pd (II)-Creatine, ${ }^{63)}$ QnPh-Ti(IV)-Chlorphenira, ${ }^{67)}$ QnPh-Fe(III)-Nalidix, Piromidic acid ${ }^{97)}$

\section{予備濃縮法の併用}

微量成分の前濃縮法として MF 法, 各種吸着体 を用いる方法は，簡便，迅速で，高価な特殊試薬，
機器を必要とせず，かつ高い濃縮係数を得る利点を 有することより，金属錯体の液体抽出に代る脂溶性 $\mathrm{MF}$ を用いる前濃縮法を(1) $\{\mathrm{R}\}$ と $\{\mathrm{M}\}$ 間の反応， 及び(2)の $\{(\mathrm{R}-\mathrm{M})\}$ と $\{\mathrm{Org}\}$ との反応への活用を 試みた。すなわち, 脂溶性界面活性剤 Capriq 共存 下に得られる $\{\mathrm{PAN}-\mathrm{Fe}(\mathrm{III})\}$ 錯体の MF 前濃縮操 作として，ニトロセルロース製 MF（粒子経 0.3 $\mu \mathrm{m})$ 上に $\{(\mathrm{PAN}-\mathrm{Fe}(\mathrm{III}))-\mathrm{Capriq}\}$ 会合体をろ別 後, ろ紙とともに会合体をジメチルスルホキシド （DMSO）に溶解後, $\mathrm{Cu}(\mathrm{II})$ の共存する際, 三次微 分法の $\lambda_{3} 660 \mathrm{~nm}, \lambda_{4} 720 \mathrm{~nm}$, また Cu(II)の共存し ない際， $\lambda_{1} 520 \mathrm{~nm}, \lambda_{2} 590 \mathrm{~nm}$ 間の三次微分距離の $\mathrm{d}^{3} \mathrm{~A} / \mathrm{d} \lambda^{3}$ 值を測定することにより，これら $\mathrm{Cu}(\mathrm{II})$ などの共存イオンの影響を半減させ， $1.0-10.0 \mu \mathrm{g} /$ $5 \mathrm{ml} \mathrm{Fe}$ (III) の定量が可能となつた. ${ }^{148)}$ 同じよう に, 分散剂 PVA 共存下の $\{($ T.Cl.Fl-Pd (II) $)$ - パパ ベリン (Papav. $\mathrm{HCl})\}$ 会合錯体 $\left.{ }^{82}\right)$ の $\mathrm{MF}$ 前濃縮操作 で 0-20 $\mu \mathrm{g} / 5 \mathrm{ml}$ Papav. $\mathrm{HCl}$ が水相内定量法の約 2 倍の鋭敏度で定量できた。 ${ }^{86)}$ グルコシド抗生物質の ゲンタマイシン $(\mathrm{GM})$ と $\{\mathrm{QnPh}-\mathrm{U}(\mathrm{VI})\}$ 間の会 合体も MF 上濃縮操作により, 水相内定量法の約

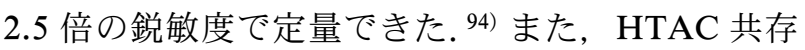
下の $\{\mathrm{QnPh}-\mathrm{Fe}(\mathrm{III})\}$ の $\mathrm{MF}$ 前濃縮操作により, 0 $-2.5 \mu \mathrm{g} / 5 \mathrm{ml} \mathrm{Fe}$ (III) が, ${ }^{134)}\{$ (Phloxin-Pd (II) Thiamine $\}$ 錯体のポリエチレングリコール（PEG） 併用下の MF 前濃縮法で， $0-0.5 \mu \mathrm{g} / 5 \mathrm{ml} \mathrm{Pd}$ (II) が，それぞれ定量された. ${ }^{121)} さ ら に ，\{(\mathrm{PV}-\mathrm{Sn}(\mathrm{IV}))$ -HSA $\}$ 会合体が，アセチルセルローズ製 MF 上に 前濃縮後, その会合体のみを水酸化ナトリウム液に

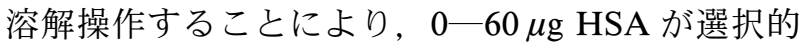
に定量された（Table 12)，(Fig. 12,13).155)

\section{高次（三次）微分法の採用}

従来の 0 次微分法に代る高次微分法は, 感度, 選 択性に優れていることより， $\{\mathrm{R}-\mathrm{M}\}$ 及び $\{(\mathrm{R}-\mathrm{M})$ -Org $\}$ 反応体への高次微分法の採用を検討した. その結果， QnPh を用いる Rh(III)の定量に際し， 陽イオン性界面活性剂, HPC を用い, 微分法（ $\lambda_{1}$ $\left.500 \mathrm{~nm}, \lambda_{2} 530 \mathrm{~nm}, \lambda_{3} 560 \mathrm{~nm}\right)$ により，見掛けの $\mathrm{d}^{3}$ $\mathrm{A} / \mathrm{d} \lambda^{3}=7.37 \times 10^{5}$ で, $0-10 \mu \mathrm{g} \mathrm{Rh}(\mathrm{III})$ が, ${ }^{131)}\{\mathrm{Ag}$ (I) - アデニン -Eosine $\}$ 会合体を用いる三次微分吸

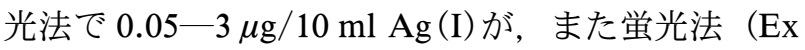
$470 \mathrm{~nm}, \operatorname{Em} 560 \mathrm{~nm})$ で $0.05-4 \mu \mathrm{g} / 10 \mathrm{ml} \mathrm{Ag}$ (I) が $\Delta \mathrm{G}=-6.34 \mathrm{kcal} \mathrm{mol}^{-1}, \Delta \mathrm{H}=28.17 \mathrm{kcal} \mathrm{mol}^{-1}, \Delta \mathrm{S}$ 
Table 12. The Apparent Molar Absorptivities of Amino Glycoside Antibiotics Obtained by $\{\mathrm{QnPh}-\mathrm{U}(\mathrm{VI})\}$ Method

\begin{tabular}{lc}
\hline \hline \multicolumn{1}{c}{ Compound } & $\begin{array}{c}\text { Apparent molar absorptivity at } 565 \mathrm{~nm} \\
\varepsilon / 1 \mathrm{~mol}^{-1} \mathrm{~cm}^{-1}\end{array}$ \\
\hline Gentamicin (GM) & $4.2 \times 10^{5}$ \\
Toburamycin (TOB) & $2.6 \times 10^{5}$ \\
Viomycin & $0.5 \times 10^{5}$ \\
Kanamycin & $1.0 \times 10^{5}$ \\
Streptomycin (SM) & $4.9 \times 10^{5}$
\end{tabular}

$\mathrm{U}(\mathrm{VI}): 1.0 \times 10^{-14} \mathrm{~mol} / \mathrm{l}, \mathrm{QuPh}: 5.0 \times 10^{-5} \mathrm{~mol} / \mathrm{l}, \mathrm{MC}: 0.5 \mathrm{ml}$ of 0.05 \% MC soln, $\mathrm{pH} 5.0$, reference: $\{\mathrm{QnPh}-\mathrm{U}(\mathrm{VI})\}$ DMSO soln.

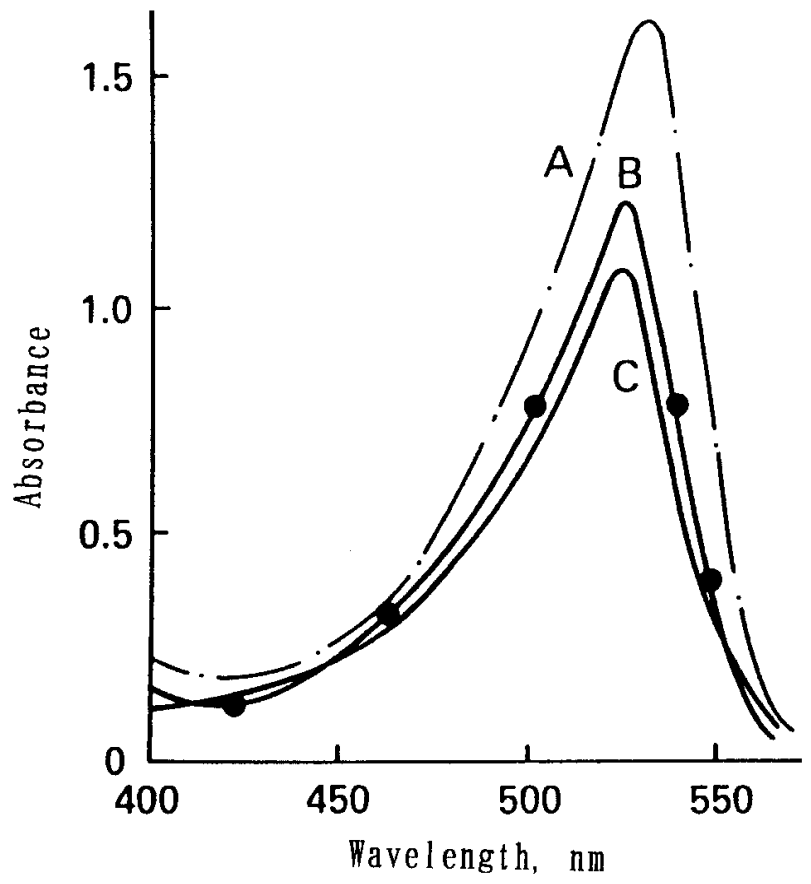

Fig. 13. Absorption Spectra of $\{$ Eosine-Ga (III)-MINO\} Solution, Eosine-MINO Solution, and \{Eosine-Ga (III) $\}$ Solution at $\mathrm{pH} 3.2$

Eosine: $6.0 \times 10^{-5} \mathrm{~mol} / \mathrm{l}, \mathrm{Ga}(\mathrm{III}): 2.0 \times 10^{-5} \mathrm{~mol} / \mathrm{l}, \mathrm{MINO}: 2.0 \times 10^{-5}$ mol/l, PVA: $0.05 \%$, reference: water.

Curve A: $\{$ Eosine-Ga (III)-MINO\} solution, Curve B: Eosine-MINO solution, Curve C: $\{$ Eosine-Ga(III) $\}$ solution.

$=-72.73 \mathrm{cal} \mathrm{mol}^{-1} \mathrm{~K}^{-1}, \mathrm{n}=0.98, \mathrm{k}=4.10 \times 10^{4} \mathrm{M}^{-1}$ として定量できた. ${ }^{146)}\{\mathrm{PAR}-\mathrm{Fe}(\mathrm{VI})\}$ 錯体の三次 微分法（ $\lambda_{1}=527 \mathrm{~nm}, \lambda_{2}=560 \mathrm{~nm} ）$ により, 0-8.0 $\mu \mathrm{g} / 10 \mathrm{ml} \mathrm{Fe}(\mathrm{III})$ を 0 次法のほぼ, 30 倍の鋭敏度で 定量できた. ${ }^{148)}$ PAR-U(VI) 間の反応においても, 第 4 級アンモニウム塩のベンチルジメチルステアリ ルトリメチルアンモニウム塩（BSTAC）の共存下, 0 次微分法で 0.3-60 $\mu \mathrm{g} \mathrm{U}(\mathrm{VI})$ が, 三次微分法 $\left(\lambda_{1}\right.$ $\left.594 \mathrm{~nm}, \lambda_{2} 565 \mathrm{~nm}\right)$ により 0 次法のほぼ 12 倍の感 度で，0-5 $\mu \mathrm{g} \mathrm{U}(\mathrm{VI})$ が定量できた。 ${ }^{154}$ \{ Eosine-

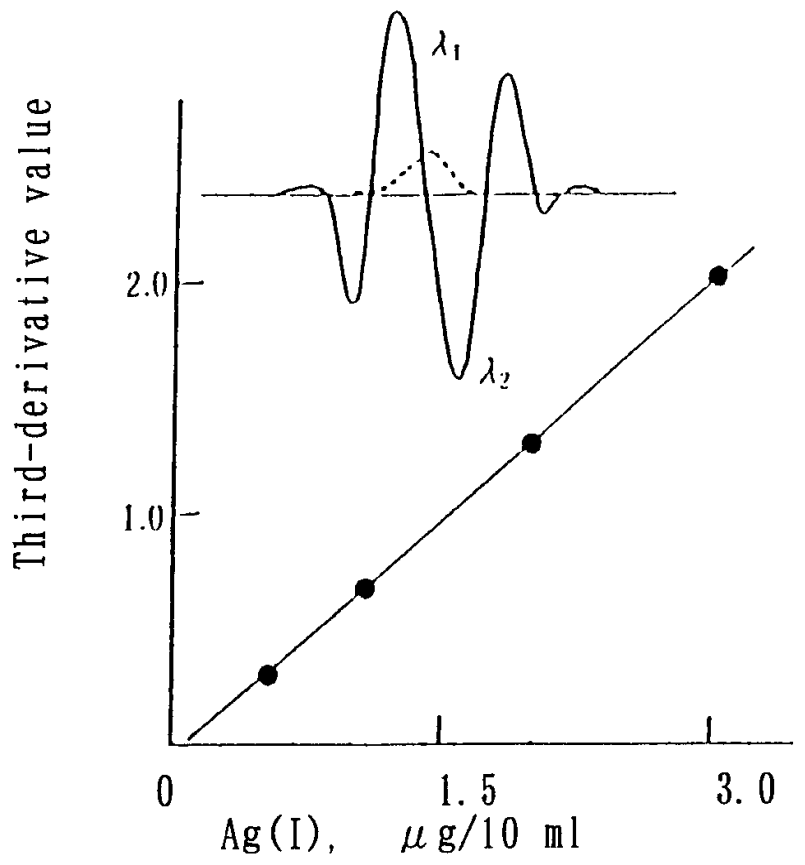

Fig. 14. Calibration Curve for $\mathrm{Ag}(\mathrm{I})$ in Third-Derivative Spectrophotometry

Eosine: $7.5 \times 10^{-5} \mathrm{~mol} / \mathrm{L}$, adenine: $3.0 \times 10^{-4} \mathrm{~mol} / \mathrm{l}, \mathrm{PVP}: 0.05 \%, \mathrm{pH}$ 6.0 , reference: reagent blank.

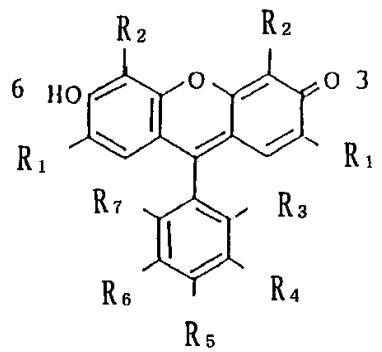

Fig. 15. Chemical Structure of Xanthene Derivatives

Adenine-Ag (I) \} 会合体生成反応を用いる三次微分 法 $\left(\lambda_{1} 540.5 \mathrm{~nm}, \lambda_{2} 573 \mathrm{~nm}\right)$ においても，0 次微分 法のほぼ 5一10 倍の鋭敏度で $\mathrm{Ag}(\mathrm{I})$ が定量 ${ }^{146)}$ でき るなど，高次微分法採用による高感度化並びに選択 性の向上が観察された（Fig. 14）.

\section{おわりに}

各種界面活性剂併用下（陽イオン, 陰イオン, 非 イオン及び両イオン性界面活性剤の単独あるいはそ の組合わせ）における各種ヒドロキシフルオラン系 色素 $\{\mathrm{R}\}$ と金属イオン $\{\mathrm{M}\}$ 間の反応を系統的に 検討した (Fig. 15)。 その結果, Table 13 に見られ るキサンテン系有機試薬 $\{\mathrm{R}\}$ を用い，弱酸性～中 性領域下に，HTAC，HPC などの第 4 級アンモニ 
Table 13. Structure of Phthalein Derivatives

\begin{tabular}{l|ccccccc}
\hline \hline \multicolumn{1}{c|}{ Dyes $^{a)}$} & $\mathrm{R}_{1}$ & $\mathrm{R}_{2}$ & $\mathrm{R}_{3}$ & $\mathrm{R}_{4}$ & $\mathrm{R}_{5}$ & $\mathrm{R}_{6}$ & $\mathrm{R}_{7}$ \\
\hline Gall & $\mathrm{H}$ & $\mathrm{OH}$ & $\mathrm{COOH}$ & $\mathrm{H}$ & $\mathrm{H}$ & $\mathrm{H}$ & $\mathrm{H}$ \\
Cl. Gall & $\mathrm{Cl}$ & $\mathrm{OH}$ & $\mathrm{COOH}$ & $\mathrm{H}$ & $\mathrm{H}$ & $\mathrm{H}$ & $\mathrm{H}$ \\
Br. Gall & $\mathrm{Br}$ & $\mathrm{OH}$ & $\mathrm{COOH}$ & $\mathrm{H}$ & $\mathrm{H}$ & $\mathrm{H}$ & $\mathrm{H}$ \\
T. Cl. Gall & $\mathrm{H}$ & $\mathrm{OH}$ & $\mathrm{COOH}$ & $\mathrm{Cl}$ & $\mathrm{Cl}$ & $\mathrm{Cl}$ & $\mathrm{Cl}$ \\
PR & $\mathrm{H}$ & $\mathrm{OH}$ & $\mathrm{SO}_{3} \mathrm{H}$ & $\mathrm{H}$ & $\mathrm{H}$ & $\mathrm{H}$ & $\mathrm{H}$ \\
Pyfl & $\mathrm{H}$ & $\mathrm{OH}$ & $\mathrm{H}$ & $\mathrm{H}$ & $\mathrm{H}$ & $\mathrm{H}$ & $\mathrm{H}$ \\
Gall. $\mathrm{CH}_{3}$ & $\mathrm{H}$ & $\mathrm{OH}$ & $\mathrm{COOCH}$ & $\mathrm{H}$ & $\mathrm{H}$ & $\mathrm{H}$ & $\mathrm{H}$ \\
T. Cl. Gall. $\mathrm{CH}_{3}$ & $\mathrm{H}$ & $\mathrm{OH}$ & $\mathrm{COOCH}$ & $\mathrm{Cl}$ & $\mathrm{Cl}$ & $\mathrm{Cl}$ & $\mathrm{Cl}$ \\
T. Br. Gall & $\mathrm{H}$ & $\mathrm{OH}$ & $\mathrm{COOH}$ & $\mathrm{Br}$ & $\mathrm{Br}$ & $\mathrm{Br}$ & $\mathrm{Br}$ \\
Fl & $\mathrm{H}$ & $\mathrm{H}$ & $\mathrm{COOH}$ & $\mathrm{H}$ & $\mathrm{H}$ & $\mathrm{H}$ & $\mathrm{H}$ \\
Eosine & $\mathrm{Br}$ & $\mathrm{Br}$ & $\mathrm{COOH}$ & $\mathrm{H}$ & $\mathrm{H}$ & $\mathrm{H}$ & $\mathrm{H}$ \\
Phloxine & $\mathrm{Br}$ & $\mathrm{Br}$ & $\mathrm{COOH}$ & $\mathrm{Cl}$ & $\mathrm{Cl}$ & $\mathrm{Cl}$ & $\mathrm{Cl}$ \\
QnPh & $\mathrm{OH}$ & $\mathrm{H}$ & $\mathrm{COOH}$ & $\mathrm{H}$ & $\mathrm{H}$ & $\mathrm{H}$ & $\mathrm{H}$ \\
Cl. QnPh & $\mathrm{OH}$ & $\mathrm{Cl}$ & $\mathrm{COOH}$ & $\mathrm{H}$ & $\mathrm{H}$ & $\mathrm{H}$ & $\mathrm{H}$ \\
Br. QnPh & $\mathrm{OH}$ & $\mathrm{Br}$ & $\mathrm{COOH}$ & $\mathrm{H}$ & $\mathrm{H}$ & $\mathrm{H}$ & $\mathrm{H}$ \\
T. Cl. QnPh & $\mathrm{OH}$ & $\mathrm{H}$ & $\mathrm{COOH}$ & $\mathrm{Cl}$ & $\mathrm{Cl}$ & $\mathrm{Cl}$ & $\mathrm{Cl}$ \\
COOH. Phfl & $\mathrm{OH}$ & $\mathrm{H}$ & $\mathrm{H}$ & $\mathrm{H}$ & $\mathrm{COOH}$ & $\mathrm{H}$ & $\mathrm{H}$ \\
Sul. Phfl & $\mathrm{OH}$ & $\mathrm{H}$ & $\mathrm{SO}{ }_{3} \mathrm{H}$ & $\mathrm{H}$ & $\mathrm{H}$ & $\mathrm{H}$ & $\mathrm{H}$ \\
Phfl & $\mathrm{OH}$ & $\mathrm{H}$ & $\mathrm{H}$ & $\mathrm{H}$ & $\mathrm{H}$ & $\mathrm{H}$ & $\mathrm{H}$ \\
F. Phfl & $\mathrm{OH}$ & $\mathrm{H}$ & $\mathrm{H}$ & $\mathrm{F}$ & $\mathrm{H}$ & $\mathrm{H}$ & $\mathrm{H}$ \\
Van. fl & $\mathrm{OH}$ & $\mathrm{H}$ & $\mathrm{H}$ & $\mathrm{OCH}$ & $\mathrm{H}$ & $\mathrm{H}$ & $\mathrm{H}$ \\
Sal. fl & $\mathrm{OH}$ & $\mathrm{H}$ & $\mathrm{H}$ & $\mathrm{OH}$ & $\mathrm{H}$ & $\mathrm{H}$ & $\mathrm{H}$ \\
QnPh. CH & $\mathrm{OH}$ & $\mathrm{H}$ & $\mathrm{COOCH}$ & $\mathrm{H}$ & $\mathrm{H}$ & $\mathrm{H}$ & $\mathrm{H}$ \\
\hline
\end{tabular}

a) Gall: gallein, Cl. Gall: 2,7-dichlorogallein, Br. Gall: 2,7-dibromogallein, T. Cl. Gall: 3', 4', 5', 6' tetrachlorogallein, T. Br. Gall: 3', 4', 5', 6' -tetrabromo gallein, PR: pyrogallor red, Phfl: phenylfluorone, Gall. $\mathrm{CH}_{3}$ : gallein methyl ester, T. Cl. Gall. $\mathrm{CH}_{3}: 3,4,5,6$-tetrachlorogallein methylester, Fl: fluorescein, QnPh: Ohydroxyhydroquinonephthalein, $\mathrm{Cl}$. QnPh: 4,5-dichloro O-hydroxyhydroquinonephthalein, $\mathrm{Br}$. QnPh: 4,5dibromo O-hydroxyhydroquinonephthalein, T. Cl. QnPh: 3', 4', 5', 6'-tetrachloro O-hydroxyhydroquinonephthalein, $\mathrm{COOH}$. Phfl: carboxyphenylfluorone, Sul. Phfl: sulfophenylfluorone, Phfl: phenylfluorone, F. Phfl: fluorophenylfluorone, Van. fl: vanylfluorone, Sal. fl: salicylfluorone, QnPh. $\mathrm{CH}_{3}$ : O-hydroxyhydroquinonephthalein methylester.

ウム塩型の陽イオン性界面活性剂を共存させた際, $\{\mathrm{R}\}$ - 多価金属イオン $\{\mathrm{M}\}$ 間の反応は明瞭で，界 面活性剂共存に伴う $\{\mathrm{R}\}$ の酸解離の促進, 高次錯 体の生成と安定化，ミセル形成による濃縮と定量感 度の上昇，並びに再現性の向上などが観察され，こ れら試薬 $\{\mathrm{R}\}$ ，界面活性剤を用いる金属及び非金 属イオン $\{\mathrm{M}\}$ の吸光光度定量法が確立された (Table 14).

同じように, 発蛍光性の QnPh, Fl 誘導体, 及び キノリルアミン誘導体を $\{\mathrm{R}\}$ に, 主として非イオ ン性界面活性剂を併用する $\{\mathrm{M}\}$ の蛍光定量法も提 唱した。

さらに，従来用いられてきている $\{\mathrm{M}\}$ あるいは $\{\mathrm{R}\}$ 単独と医薬品あるいは生体関連物質などの有 機物質である分析対象成分 $\{\mathrm{Org}\}$ 間の反応活用に
代えて，各種水溶性界面活性剂併用下， $\{\mathrm{R}\}$ と $\{\mathrm{M}\}$ 及び $\{\mathrm{Org}\}$ 間の反応を活用した $\{\mathrm{Org}\}$ 分析 法を新たに確立提唱した。すなわち，水溶性界面活 性剂共存下に得られる $\{\mathrm{R}\},\{\mathrm{M}\}$ と $\{\mathrm{Org}\}$ 間の $\{(\mathrm{R}-\mathrm{M})-\mathrm{Org}\}$ 会合体反応，あるいは $\{\mathrm{R}-\mathrm{M}\}$ 錯体 と $\{\mathrm{Org}\}$ 間の競合反応（\{R-Org $\}$ M-Org $\})$ を活 用する水相内における簡便, 迅速, 高感度, 選択的 な $\{\mathrm{Org}\}$ の吸光並びに蛍光光度定量法を新たに,

Table 15 のように提唱できた.

謝辞本研究は, 主として本分析化学教室の藤 田芳一助教授とともに, 山口敬子助手, 及び豊田美 奈子, 生田絹子, 北野尚子, 坂口紀美子, 鎌田吉 介, 真野豊子, 井田まさ子, 山崎美紗子などの元助 手諸君, 並びに本学大学院修了生, 学部卒業生など 
Table 14. Photometric Analysis of Inorganic Ions by $\{$ Org $\}-\{\mathbf{M}\}$ Reaction

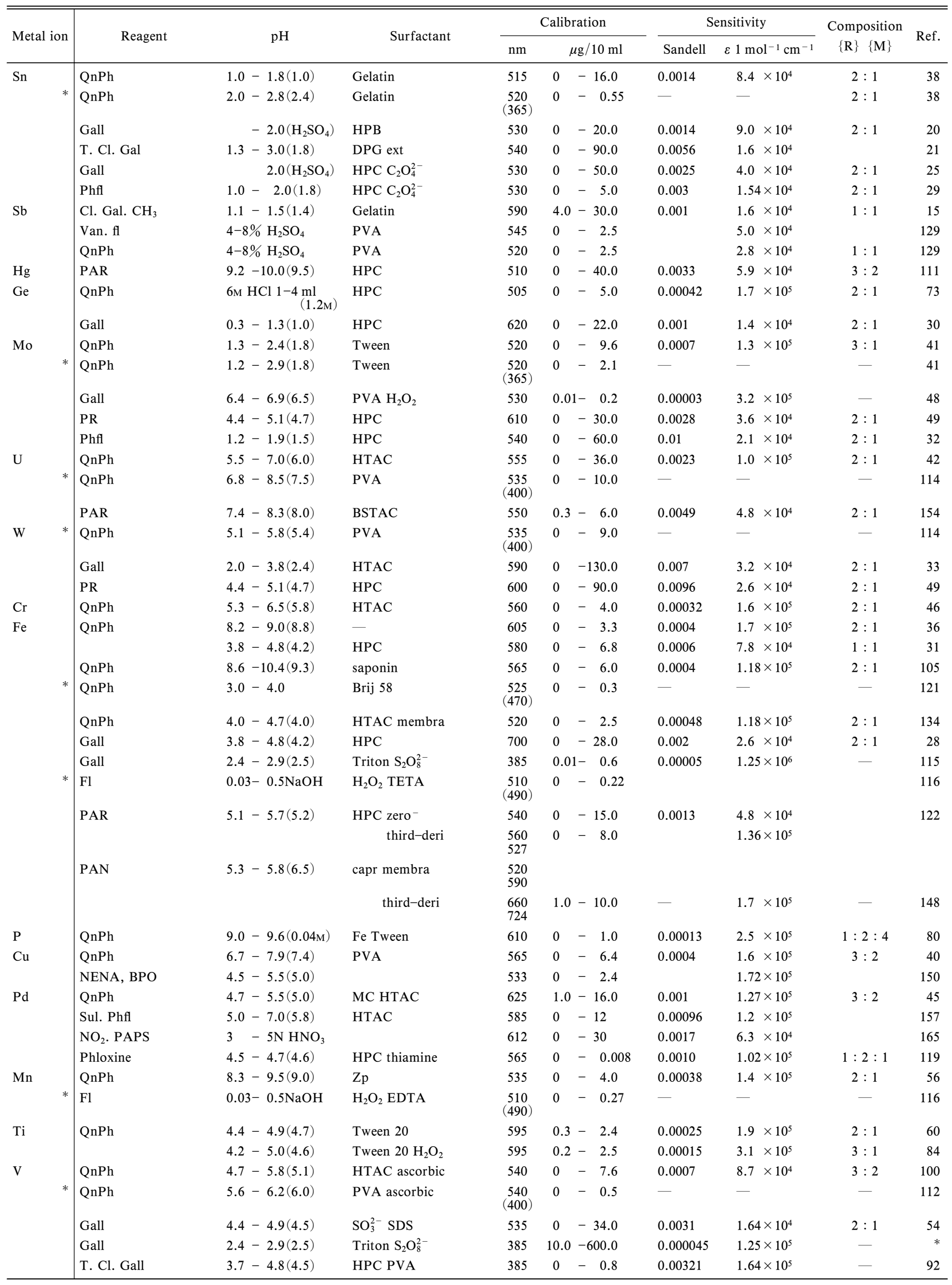


Table 14. continued

\begin{tabular}{|c|c|c|c|c|c|c|c|c|c|c|}
\hline \multirow{2}{*}{ Metal ion } & \multirow{2}{*}{ Reagent } & \multirow{2}{*}{$\mathrm{pH}$} & \multirow{2}{*}{ Surfactant } & \multicolumn{3}{|c|}{ Calibration } & \multicolumn{2}{|c|}{ Sensitivity } & \multirow{2}{*}{$\begin{array}{c}\text { Composition } \\
\quad\{\mathbf{R}\}\{\mathbf{M}\}\end{array}$} & \multirow{2}{*}{ Ref. } \\
\hline & & & & $\mathrm{nm}$ & & $\mu \mathrm{g} / 10 \mathrm{ml}$ & Sandell & $\varepsilon 1 \mathrm{~mol}^{-1} \mathrm{~cm}^{-1}$ & & \\
\hline $\mathrm{Sc}$ & QnPh & $4.7-5.8(5.1)$ & HTAC ascorbic & 555 & 0 & -4.5 & 0.0005 & $1.0 \times 10^{5}$ & $3: 2$ & 91 \\
\hline \multirow{2}{*}{ In } & QnPh & $5.2-6.2(5.4)$ & $\mathrm{HPC}$ & 560 & 0 & -10.0 & 0.0008 & $1.3 \times 10^{5}$ & $2: 1$ & 90 \\
\hline & T. Cl. Gall & $4.2-5.2(4.4)$ & HPC & 620 & 0 & -45.0 & 0.0032 & $4.8 \times 10^{4}$ & $2: 1$ & 37 \\
\hline \multirow[t]{2}{*}{$\mathrm{Al}$} & QnPh & $8.2-9.0(8.8)$ & - & 530 & 0 & $-\quad 3.2$ & 0.0002 & $1.4 \times 10^{5}$ & $2: 1$ & 36 \\
\hline & $\mathrm{QnPh}$ & $5.0-7.8(5.5)$ & Zp Brij 35 & 535 & 0 & -2.0 & 0.00013 & $2.1 \times 10^{5}$ & $2: 1$ & 103 \\
\hline \multirow[t]{5}{*}{$\mathrm{Ga}$} & Gall & $4.6-5.5(4.9)$ & $\mathrm{HPC}$ & 600 & 0 & -8.0 & 0.0008 & $3.2 \times 10^{4}$ & $2: 1$ & 39 \\
\hline & QnPh & $6.2-7.6(6.4)$ & HTAC & 550 & 0 & -6.5 & 0.0005 & $1.3 \times 10^{5}$ & $2: 1$ & 106 \\
\hline & QnPh & $4.3-5.3(4.5)$ & TTAC & $\begin{array}{c}543 \\
(345)\end{array}$ & 0 & $-280 \mathrm{ng}$ & - & - & - & 152 \\
\hline & Br. PADAP & $(3.9)$ & SDS Brij 35 & 575 & 0 & -9.0 & & $1.3 \times 10^{5}$ & & 164 \\
\hline & Zincon & $3.4-4.1(3.7)$ & Tween & 640 & 0 & -35.0 & 0.0029 & $2.4 \times 10^{4}$ & $3: 2$ & 88 \\
\hline \multirow[t]{9}{*}{$\mathrm{Bi}$} & $\mathrm{QnPh}$ & $1.7-2.1(1.8)$ & Brij 58 & 520 & 0 & -35.0 & 0.0002 & $9.03 \times 10^{4}$ & $3: 1$ & 109 \\
\hline & Gall & $3.0\left(\mathrm{HNO}_{3}\right)$ & - & 570 & 0 & -50.0 & 0.0019 & $2.93 \times 10^{4}$ & $1: 1$ & 11 \\
\hline & Gall. IDA & $3.2\left(\mathrm{HNO}_{3}\right)$ & - & 540 & 0 & -70.0 & 0.001 & $4.63 \times 10^{4}$ & $1: 1$ & 11 \\
\hline & МТB & $0.5-2.1(1.5)$ & - & 550 & 0 & -17.0 & 0.002 & $1.2 \times 10^{4}$ & $1: 1$ & 16 \\
\hline & Мтв & $0.6-2.4(1.5)$ & DPG ext & 560 & 0 & -10.5 & 0.025 & $2.2 \times 10^{3}$ & $1: 1$ & 16 \\
\hline & MXB & $1.0-1.4(1.2)$ & - & 585 & 0 & -200.0 & 0.025 & $8.0 \times 10^{3}$ & $1: 1$ & 26 \\
\hline & Cl. Gal. $\mathrm{CH}_{3}$ & $1.1-1.4(1.2)$ & $\mathrm{PVA}_{2} \mathrm{O}_{3}^{2-}$ & $\begin{array}{l}380 \\
495\end{array}$ & 0 & -17.0 & 0.0024 & $7.2 \times 10^{4}$ & - & 24 \\
\hline & Cl. Gal. $\mathrm{CH}_{3}$ & $4.0-5.0(4.1)$ & DPG ext & 640 & 10.0 & -80.0 & 0.022 & $1.3 \times 10^{4}$ & $1: 1$ & 19 \\
\hline & Cl. Gal. $\mathrm{CH}_{3}$ & $1.6-2.0(1.8)$ & gelatin & 620 & 0 & -100.0 & 0.02 & $1.2 \times 10^{4}$ & $1: 1$ & 15 \\
\hline \multirow[t]{2}{*}{$\mathrm{Zn}$} & QnPh & $6.9-7.3(7.2)$ & Chitosan & 555 & 0 & -10.0 & & $9.2 \times 10^{4}$ & & 125 \\
\hline & Мтв & $7.6-9.0(8.2)$ & Oxine & 530 & 0 & $-\quad 3.0$ & 0.005 & $2.1 \times 10^{4}$ & $1: 1$ & 50 \\
\hline $\mathrm{Cd}$ & MTB & $7.6-9.0(8.2)$ & Oxine & 620 & 0 & -4.0 & 0.003 & $2.2 \times 10^{4}$ & $1: 1$ & 50 \\
\hline \multirow[t]{2}{*}{$\mathrm{Ni}$} & $\mathrm{QnPh}$ & $8.8-9.4(9.0)$ & $\mathrm{Zp}$ & 545 & 0 & -7.0 & 0.00045 & $1.26 \times 10^{5}$ & $2: 3$ & 128 \\
\hline & Zincon & $6.0-8.3(7.0)$ & PVA & 470 & 0 & -42.0 & 0.0047 & $3.1 \times 10^{4}$ & - & 99 \\
\hline \multirow[t]{8}{*}{ Co } & $\mathrm{QnPh}$ & $10.1-11.0(10.3)$ & $\begin{array}{l}\text { HTAC Triton X } \\
\mathrm{H}_{2} \mathrm{O}_{2}\end{array}$ & 530 & 0 & - 0.00012 & $0.15 \mathrm{pg}$ & $4.2 \times 10^{8}$ & - & 107 \\
\hline & Fl. $\mathrm{NHNH}_{2}$ & $8.8-10.2(10.0)$ & $\mathrm{Zp} \mathrm{H}_{2} \mathrm{O}_{2}$ & $\begin{array}{c}530 \\
(508)\end{array}$ & 0 & $-6.0 \mathrm{ng}$ & - & - & - & 162 \\
\hline & Zincon & $8.0-9.0(8.5)$ & HPC & 550 & 0 & -2.2 & 0.00015 & $9.5 \times 10^{4}$ & - & 99 \\
\hline & $\mathrm{Fl}$ & $0.5 \mathrm{NaOH}$ & Tiron $\mathrm{H}_{2} \mathrm{O}_{2}$ & $\begin{array}{c}510 \\
(490)\end{array}$ & 0 & -0.06 & - & - & - & 118 \\
\hline & MQAS & $9.8-10.2(10.0)$ & STAC $\mathrm{H}_{2} \mathrm{O}_{2}$ & $\begin{array}{l}400 \\
(320)\end{array}$ & 0 & -0.045 & - & - & - & 123 \\
\hline & HPMQ & $9.8-10.8(10.0)$ & STAC $\mathrm{H}_{2} \mathrm{O}_{2}$ & $\begin{array}{c}522 \\
(410)\end{array}$ & 0.2 & $-15 \mathrm{ng}$ & - & - & - & 127 \\
\hline & HAP & $8.2-9.8(9.5)$ & $\mathrm{H}_{2} \mathrm{O}_{2}$ & $\begin{array}{l}450 \\
(365)\end{array}$ & 0 & $-25 \mathrm{ng}$ & - & - & - & 140 \\
\hline & Gall. H & $6.6-7.0(6.8)$ & SDS $\mathrm{H}_{2} \mathrm{O}_{2}$ & 530 & 0 & -5.5 & 0.0046 & $1.5 \times 10^{5}$ & - & 110 \\
\hline $\mathrm{Pb}$ & Cl. Gal. $\mathrm{CH}_{3}$ & $7.2-8.8(7.4)$ & PVP Phen & $\begin{array}{l}600 \\
660\end{array}$ & 0 & -60.0 & 0.001 & $1.55 \times 10^{4}$ & $3: 2$ & 44 \\
\hline \multirow[t]{2}{*}{$\mathrm{Rh}$} & $\mathrm{QnPh}$ & $6.4-7.2(6.5)$ & HPC third deri & $\begin{array}{l}500 \\
530\end{array}$ & & & & & & \\
\hline & & & & 560 & 0 & -10.0 & & $7.37 \times 10^{5}$ & $2: 3$ & 131 \\
\hline $\mathrm{Ta}$ & $\mathrm{QnPh}$ & $0.8-1.5(1.0)$ & HTAB & 540 & 0 & -18.0 & 0.0017 & $1.07 \times 10^{5}$ & $2: 1$ & 133 \\
\hline & $\mathrm{QnPh}$ & $0.2-0.9(0.5 \mathrm{M} \mathrm{HCl})$ & HTAC & 510 & 0 & -18.0 & 0.00085 & $2.09 \times 10^{5}$ & $2: 1$ & 136 \\
\hline $\mathrm{Nb}$ & $\mathrm{QnPh}$ & $0.2-0.9(0.5 \mathrm{M} \mathrm{HCl})$ & HTAC & 520 & 0 & -10.0 & 0.00042 & $2.18 \times 10^{5}$ & $2: 1$ & 136 \\
\hline $\mathrm{Zr}$ & Cl. Gal. $\mathrm{CH}_{3}$ & $3.5-5.0(4.6)$ & $\mathrm{HPC} \mathrm{F}^{-}$ & 660 & 0 & -20.0 & 0.005 & $4.7 \times 10^{4}$ & & 27 \\
\hline & Gall & $3.8-4.8(4.6)$ & $\mathrm{HPC} \mathrm{F}^{-}$ & 600 & 0 & -20.0 & 0.0029 & $4.48 \times 10^{4}$ & $3: 2$ & 23 \\
\hline & $\mathrm{Phfl}$ & $4.0-5.0(4.6)$ & $\mathrm{HPC} \mathrm{F}^{-}$ & 560 & 0 & -7.0 & 0.002 & $5.2 \times 10^{4}$ & $2: 1$ & 32 \\
\hline & PAR & $6.7-7.3(7.0)$ & $\mathrm{HPC} \mathrm{F}^{-}$ & 540 & 0 & -12.0 & 0.0013 & $7.1 \times 10^{4}$ & $2: 1$ & 87 \\
\hline$*$ & QnPh & $4.3-5.5(4.5)$ & TTAC $\mathrm{F}^{-}$ & $\begin{array}{c}543 \\
(345)\end{array}$ & 0 & $-360 \mathrm{ng}$ & - & - & & 152 \\
\hline & XO & $2.5-4.0(3.5)$ & HPC Brij F- & 600 & 0.5 & -20.0 & 0.0013 & $7.0 \times 10^{4}$ & $2: 1$ & 108 \\
\hline Th & T. Cl. Gall & $4.3-5.5(4.6)$ & HTAC La & 650 & 0 & -17.0 & 0.0023 & $6.0 \times 10^{4}$ & $2: 1$ & 55 \\
\hline & Gall & $3.0-4.5(4.2)$ & Brij 35 LS & 620 & 0 & -50.0 & 0.005 & $4.9 \times 10^{4}$ & $2: 1$ & 96 \\
\hline & & $3.4-4.8(4.4)$ & HPC & 600 & 0 & -90.0 & 0.0013 & $2.56 \times 10^{4}$ & $2: 1$ & 102 \\
\hline & Cl. Gal. $\mathrm{CH}_{3}$ & $3.5-5.0(4.6)$ & HPC & 660 & 0 & -45.0 & 0.0013 & $5.0 \times 10^{4}$ & $2: 1$ & 27 \\
\hline & MXB & $1.5-1.6(1.6)$ & HPC & 580 & 0 & -232.0 & 0.018 & $1.6 \times 10^{4}$ & $1: 1$ & 26 \\
\hline & $\mathrm{PR}$ & $4.4-5.2(4.5)$ & PVA & 635 & 1.0 & -22.0 & 0.028 & $8.2 \times 10^{4}$ & $2: 1$ & 89 \\
\hline $\mathrm{Hf}$ & QnPh & $4.5-5.5(5.0)$ & HPC & 555 & 0 & -17.5 & 0.0017 & $5.6 \times 10^{4}$ & $2: 1$ & 70 \\
\hline $\mathrm{La}$ & PAR & $6.7-7.3(7.0)$ & $\mathrm{HPC} \mathrm{F}^{-}$ & 540 & 0 & $-\quad 5.0$ & 0.0066 & $6.2 \times 10^{4}$ & $1: 2$ & 87 \\
\hline & Gall & $3.0-4.5(4.2)$ & Brij LS & 620 & 0 & -30.0 & 0.002 & $2.1 \times 10^{4}$ & - & 96 \\
\hline
\end{tabular}


Table 14. continued

\begin{tabular}{|c|c|c|c|c|c|c|c|c|c|c|c|c|}
\hline \multirow{2}{*}{\multicolumn{2}{|c|}{ Metal ion }} & \multirow{2}{*}{ Reagent } & \multirow{2}{*}{$\mathrm{pH}$} & \multirow{2}{*}{ Surfactant } & \multicolumn{3}{|c|}{ Calibration } & \multicolumn{3}{|c|}{ Sensitivity } & \multirow{2}{*}{$\begin{array}{l}\text { Composition } \\
\qquad\{\mathbf{R}\}\{\mathbf{M}\}\end{array}$} & \multirow{2}{*}{ Ref. } \\
\hline & & & & & $\mathrm{nm}$ & & $\mathrm{g} / 10 \mathrm{ml}$ & Sandell & $\varepsilon 1 \mathrm{mo}$ & $\mathrm{ol}^{-1} \mathrm{~cm}^{-1}$ & & \\
\hline \multirow{2}{*}{\multicolumn{2}{|c|}{$\mathrm{Ce}$}} & Cl. Gal. $\mathrm{CH}_{3}$ & $7.2-8.8(7.4)$ & PVP Oxine & $\begin{array}{l}600 \\
660\end{array}$ & 0 & -40.0 & 0.0055 & 1.75 & $5 \times 10^{4}$ & $2: 1$ & 44 \\
\hline & & MXB & $7.6-9.8(7.7)$ & $\mathrm{HPC}$ & 645 & 5.0 & -35.0 & 0.002 & 1.3 & $\times 10^{4}$ & - & 18 \\
\hline \multicolumn{2}{|l|}{ Rare } & Cl. Gal. $\mathrm{CH}_{3}$ & $6.3-7.3(7.1)$ & $\mathrm{HPC}$ & $\begin{array}{l}655- \\
670\end{array}$ & 0 & -40.0 & 0.005 & 3.8 & $\times 10^{4}$ & $2: 1$ & 17 \\
\hline \multicolumn{2}{|l|}{$\mathrm{Sm}$} & PR & $4.4-5.2(4.5)$ & PVA & 635 & 0.5 & -10.0 & 0.0015 & 1.0 & $\times 10^{5}$ & $2: 1$ & 89 \\
\hline \multicolumn{2}{|l|}{ Dy } & PAR & $9.6-11.0(10.0)$ & HPC Triton & 540 & 0 & -20.0 & 0.0023 & 7.2 & $\times 10^{4}$ & $2: 1$ & 139 \\
\hline \multicolumn{2}{|l|}{$\mathrm{Gd}$} & $\mathrm{QnPh}$ & $10.4-11.2(10.8)$ & HPC Brij 35 & 590 & 0 & -16.0 & 0.0013 & 1.2 & $\times 10^{5}$ & $2: 1$ & 142 \\
\hline \multirow[t]{5}{*}{$\mathrm{Ag}$} & & Cl. Gal. $\mathrm{CH}_{3}$ & $6.8-7.8(7.4)$ & PVP Phen & $\begin{array}{l}630 \\
650\end{array}$ & 0 & -30.0 & 0.0038 & 1.6 & $\times 10^{4}$ & $1: 1$ & 35 \\
\hline & & T. Cl. fl & $9.8-11.5(10.8)$ & PVP Phen & 540 & 5.4 & -21.6 & 0.003 & 3.8 & $\times 10^{4}$ & $1: 1$ & 31 \\
\hline & & Eosine & $5.2-6.6(6.0)$ & aden PVP & 560 & 0.2 & -15.0 & - & 1.1 & $\times 10^{5}$ & $1: 1$ & 146 \\
\hline & & & & third-deri & $\begin{array}{l}560 \\
470\end{array}$ & 0.05 & $5-\quad 3.0$ & & & & & \\
\hline & $*$ & T. Cl. Fl & $9.8-11.5(10.8)$ & PVP Phen & $\begin{array}{c}540 \\
(365)\end{array}$ & 0.5 & -6.0 & - & - & & - & 31 \\
\hline \multirow[t]{2}{*}{ Os } & & Gall & $6.9-8.1(7.2)$ & Brij 35 & 535 & 0 & $-\quad 0.5 \mathrm{ng}$ & 0.000085 & 2.1 & $\times 10^{9}$ & - & 141 \\
\hline & & PAR & $6.0-7.2(6.5)$ & HTAC Brij 58 & 540 & 0 & -110.0 & 0.0078 & 2.4 & $\times 10^{4}$ & & 137 \\
\hline $\mathrm{Tl}$ & $*$ & T. Cl. Fl+PR & $7.8-8.3(8.0)$ & AM 301 & $\begin{array}{c}545 \\
(525)\end{array}$ & 0 & -4.0 & - & - & & - & 147 \\
\hline & $*$ & DPD & $3.2-4.8(4.0)$ & EDTA $\mathrm{S}_{2} \mathrm{O}_{8}^{2-}$ & 552 & 0 & -0.3 & & 1.9 & $\times 10^{6}$ & & 158 \\
\hline & & Phlox Thia & $4.3-4.9$ & Thiam & 570 & 0.2 & -8.0 & 0.00094 & 2.1 & $\times 10^{5}$ & $1: 2: 2$ & 166 \\
\hline \multirow{2}{*}{\multicolumn{2}{|c|}{$\mathrm{CN}^{-}$}} & Cl. Gal. $\mathrm{CH}_{3}$ & $6.9-7.8(7.4)$ & PVP Phen Ag & 630 & 0 & -3.0 & 0.0009 & 3.5 & $\times 10^{4}$ & - & 35 \\
\hline & & PAR & $9.2-10.0(9.5)$ & $\mathrm{HPC} \mathrm{Hg}$ & 510 & 0 & -10.0 & 0.0011 & 2.5 & $\times 10^{4}$ & - & 111 \\
\hline \multicolumn{2}{|l|}{$\mathrm{S}_{2} \mathrm{O}_{3}^{2-}$} & Cl. Gal. $\mathrm{CH}_{3}$ & $6.9-7.8(7.4)$ & PVP Phen Ag & 630 & 0 & -6.5 & 0.001 & 6.1 & $\times 10^{4}$ & - & 35 \\
\hline \multirow[t]{2}{*}{$\mathrm{I}^{-}$} & & Cl. Gal. $\mathrm{CH}_{3}$ & $6.9-7.8(7.4)$ & PVP Phen Ag & 630 & 0 & -7.5 & 0.002 & 3.0 & $\times 10^{4}$ & - & 35 \\
\hline & & Cl. Gal. $\mathrm{CH}_{3}$ & $0.5-1.25 \mathrm{H}_{2} \mathrm{SO}_{4}$ & $\mathrm{HPC} \mathrm{H}_{2} \mathrm{O}_{2}$ & 510 & 0.1 & -0.6 & 0.0001 & 8.0 & $\times 10^{4}$ & - & 22 \\
\hline \multirow{2}{*}{\multicolumn{2}{|c|}{$\mathrm{NO}_{2}^{-}$}} & Cl. Gal. $\mathrm{CH}_{3}$ & $0.5-1.25 \mathrm{H}_{2} \mathrm{SO}_{4}$ & PVP & 490 & 0 & -18.4 & 0.0005 & 6.0 & $\times 10^{4}$ & - & 22 \\
\hline & & Gall & $1.7-2.5(1.7)$ & HTAC Mo & 620 & 0 & -20.0 & 0.0045 & - & & - & 110 \\
\hline $\mathrm{S}^{2-}$ & $*$ & Cl. Fl. $\mathrm{Hg}_{4}$ & $6.4-7.0(6.8)$ & PVP & $\begin{array}{c}550 \\
(365)\end{array}$ & 0 & -40.0 & - & - & & - & 47 \\
\hline \multirow[t]{3}{*}{$\mathrm{F}^{-}$} & & Gall & $3.8-4.8(4.6)$ & $\mathrm{HPC} \mathrm{Zr}$ & 610 & 0.5 & $-\quad 3.8$ & 0.0011 & 2.0 & $\times 10^{4}$ & - & 23 \\
\hline & & XO & $2.5-4.0(3.5)$ & HPC Brij Zr & 600 & 0 & -20.0 & 0.0016 & 1.4 & $\times 10^{4}$ & - & 108 \\
\hline & & PAR & $6.7-7.3(7.0)$ & $\mathrm{HPC} \mathrm{Hf}$ & 540 & 2.0 & -10.0 & 0.02 & 9.5 & $\times 10^{4}$ & - & 87 \\
\hline \multirow[t]{7}{*}{$\mathrm{H}_{2} \mathrm{O}_{2}$} & $*$ & HPMQ & $9.8-10.8(10.0)$ & STAC Co & $\begin{array}{c}522 \\
(410)\end{array}$ & 0 & -2.5 & - & - & & - & 132 \\
\hline & $*$ & Fl. $\mathrm{NHNH}_{2}$ & $8.8-10.2(10.0)$ & $\mathrm{Zp}$ & $\begin{array}{c}530 \\
(508)\end{array}$ & 0 & $-1000 \mathrm{ng}$ & - & - & & - & 162 \\
\hline & & Sul. Phfl-Ti(IV) & $5.0-6.6(5.5)$ & Triton X HTAC & 610 & 0.2 & -2.0 & & 2.3 & $\times 10^{5}$ & & 130 \\
\hline & & QnPh-Ti(IV) & $1.0-2.2(1.5)$ & HTAC EDTA & 530 & 0.02 & $2-\quad 2.0$ & & 2.3 & $\times 10^{5}$ & & 149 \\
\hline & & 5-Br. PAPS-Mo(VI) & $1.6-2.3(1.9)$ & - & 640 & 0 & -8.5 & & 4.6 & $\times 10^{4}$ & & 153 \\
\hline & & $5-\mathrm{NO}_{2}$. PAPS-V $(\mathrm{V})$ & $0.7-1.1(0.9)$ & SDBS & 600 & 0 & -6.8 & & 7.7 & $\times 10^{4}$ & & 153 \\
\hline & & & $5.3-7.2(6.2)$ & HTAC & 605 & 0 & -6.8 & & 9.2 & $\times 10^{4}$ & & \\
\hline
\end{tabular}

\footnotetext{
* fluorophotometry.
} 
Table 15. Photometric Analysis of Organic Compounds by $\{\mathrm{Org}\}-\{\mathbf{M}\}$ Formation in the Coexistence of Various Surfactants

\begin{tabular}{|c|c|c|c|c|c|c|c|c|c|c|}
\hline \multirow{2}{*}{\multicolumn{2}{|c|}{$\mathrm{Org}$}} & \multirow{2}{*}{$\mathbf{R}$} & \multirow{2}{*}{$\mathbf{M}$} & \multirow{2}{*}{$\mathrm{pH}$} & \multirow{2}{*}{ Surfactant } & \multicolumn{3}{|c|}{ Calibration curve } & \multirow{2}{*}{$\begin{array}{c}\text { Apparent } \\
\varepsilon, 1 \mathrm{~mol}^{-1} \mathrm{~cm}^{-1}\end{array}$} & \multirow{2}{*}{ Ref. No. } \\
\hline & & & & & & $\mathrm{nm}$ & & $\mu \mathrm{g} / 10 \mathrm{ml}$ & & \\
\hline \multirow{2}{*}{\multicolumn{2}{|c|}{ Thiamine }} & QnPh & $\mathrm{U}(\mathrm{VI})$ & $5.1-5.7(5.4)$ & MC & 550 & $0-$ & $-\quad 32.0$ & $4.9 \times 10^{4}$ & 51 \\
\hline & & Eosine & $\operatorname{Pd}(\mathrm{II})$ & $3.8-4.5(4.3)$ & $\mathrm{MC}$ & 545 & & & $6.7 \times 10^{4}$ & 104 \\
\hline Papaverine & & $\mathrm{QnPh}$ & $\mathrm{U}(\mathrm{VI})$ & $4.9-5.7(5.2)$ & $\mathrm{MC}$ & 550 & 0 & -85.0 & $4.6 \times 10^{4}$ & 53 \\
\hline & & T.Cl.Fl & $\mathrm{Pd}(\mathrm{II})$ & $5.0-5.5(5.2)$ & PVA & 540 & 0 & -75.0 & $4.0 \times 10^{4 *}$ & 82 \\
\hline & & T.Cl.Fl & $\operatorname{Pd}(\mathrm{II})$ & $3.8-4.2(4.0)$ & PVA membrane & 540 & $0-$ & $-\quad 20.0$ & $8.0 \times 10^{4 *}$ & 86 \\
\hline Berberine & & $\mathrm{QnPh}$ & $\mathrm{Zr}(\mathrm{IV})$ & $1.5-2.2(1.8)$ & SDS & 515 & $5.0-$ & $-\quad 45.0$ & $4.0 \times 10^{4}$ & 78 \\
\hline Reserpine & & QnPh & $\mathrm{U}(\mathrm{VI})$ & $4.1-4.7(4.6)$ & MC & 535 & $9.0-$ & -70.0 & $6.8 \times 10^{4}$ & 76 \\
\hline Quinine sulfate & & PR & $\mathrm{Mo}(\mathrm{VI})$ & $4.0-4.7(4.3)$ & Tween & 610 & 0 & -1120.0 & $3.8 \times 10^{4}$ & 52 \\
\hline & & $\mathrm{QnPh}$ & $\mathrm{U}(\mathrm{VI})$ & $5.0-5.6(5.3)$ & $\mathrm{MC}$ & 555 & $0-$ & -120.0 & $4.1 \times 10^{4}$ & 59 \\
\hline Tubocurarine & & $\mathrm{QnPh}$ & $\mathrm{Zr}(\mathrm{IV})$ & $2.0-2.7(2.3)$ & SDS & 515 & $0-$ & -150.0 & $3.0 \times 10^{4}$ & 69 \\
\hline Neomycin & & QnPh & $\mathrm{U}(\mathrm{VI})$ & $4.6-5.2(4.8)$ & $\mathrm{MC}$ & 545 & $3.0^{-}$ & $-\quad 50.0$ & $1.28 \times 10^{5}$ & 72 \\
\hline Toburamycin & & QnPh & $\mathrm{U}(\mathrm{VI})$ & $4.6-5.2(4.8)$ & $\mathrm{MC}$ & 545 & $2.0-$ & $-\quad 40.0$ & $1.17 \times 10^{5}$ & 72 \\
\hline Gentamicin & & $\mathrm{QnPh}$ & $\mathrm{U}(\mathrm{VI})$ & $4.8-5.2(5.0)$ & MC membrane & 565 & $0-$ & $\begin{array}{ll}- & 5.4\end{array}$ & $4.2 \times 10^{5}$ & 94 \\
\hline Cephalexin & & QnPh & $\mathrm{Pd}(\mathrm{II})$ & $4.4-5.6(5.0)$ & HTAC & 630 & $0-$ & $-\quad 17.0$ & $2.37 \times 10^{5 *}$ & 58 \\
\hline Ampicillin & & & & & & & $0-$ & $-\quad 14.0$ & $2.13 \times 10^{5 *}$ & 58 \\
\hline Minocycline & & Eosine & $\mathrm{Ga}(\mathrm{III})$ & $3.0-3.6(3.2)$ & PVA & 545 & $5.0^{-}$ & $-\quad 40.0$ & $1.1 \times 10^{5}$ & 95 \\
\hline Lincomycin & & Eosine & $\mathrm{Pd}(\mathrm{II})$ & $3.8-4.5(4.3)$ & $\mathrm{MC}$ & 545 & $5.0-$ & -70.0 & $5.5 \times 10^{4}$ & 104 \\
\hline Ofalaxacin & & Eosine & $\operatorname{Pd}(\mathrm{II})$ & $3.8-4.5(4.3)$ & $\mathrm{MC}$ & 545 & $5.0-$ & -70.0 & $4.0 \times 10^{4}$ & 104 \\
\hline Streptomycin & & $\mathrm{QnPh}$ & $\mathrm{Mn}(\mathrm{II})$ & $9.5-11.0(10.1)$ & PVP & 570 & $0-$ & $-\quad 25.0$ & $2.4 \times 10^{5}$ & 64 \\
\hline Minocycline & & QnPh & $\mathrm{Zr}(\mathrm{IV})$ & $2.0-2.7(2.3)$ & SDS & 515 & $5.0-$ & $-\quad 40.0$ & $5.5 \times 10^{4}$ & 66 \\
\hline$\beta$-Lactam & $*$ & Mercurochrome & - & $9.6-10.5(10.0)$ & PVA & $\begin{array}{c}544 \\
(470)\end{array}$ & $0-5 c$ & 50 or 60 & - & 117 \\
\hline PCG, ABPC & $*$ & & & $(10.0)$ & PVA & $\begin{array}{c}535 \\
(365)\end{array}$ & $0-1$ & 140 or 50 & & 83 \\
\hline Thiourea & $*$ & T. Cl. Fl. $\mathrm{Hg}_{4}$ & & $8.5-9.4(8.9)$ & PVP & $\begin{array}{c}555 \\
(364)\end{array}$ & $0-$ & $-\quad 19.5$ & & 34 \\
\hline Thiourea & & QnPh & $\mathrm{Pd}(\mathrm{II})$ & $4.3-5.7(5.0)$ & HTAC & 630 & 0 & $\begin{array}{l}-\quad 1.2 \\
-\end{array}$ & $3.62 \times 10^{5 *}$ & 57 \\
\hline Chlorpromazine & & QnPh & $\mathrm{Pd}(\mathrm{II})$ & $3.6-4.0(3.8)$ & SDS & 525 & 0 & -150.0 & $2.2 \times 10^{4 *}$ & 61 \\
\hline Creatine & & QnPh & $\mathrm{Pd}(\mathrm{II})$ & $5.3-5.7(5.5)$ & SDS & 615 & $0.3-$ & $\begin{array}{l}-\quad 4.0 \\
-\quad 1\end{array}$ & $2.3 \times 10^{5 *}$ & 63 \\
\hline Iodouracil & & QnPh & $\mathrm{Pd}(\mathrm{II})$ & $9.3-10.5(9.8)$ & HTAC & 630 & $0-$ & $-\quad 15.0$ & $1.15 \times 10^{5 *}$ & 65 \\
\hline Isoniazid & & $\mathrm{QnPh}$ & $\mathrm{Pd}(\mathrm{II})$ & $3.9-4.7(4.3)$ & HTAC & 635 & $0-$ & $-\quad 1.5$ & $6.2 \times 10^{5 *}$ & 62 \\
\hline Theophyline & & Eosine & $\mathrm{Pd}(\mathrm{II})$ & $3.8-4.5(4.3)$ & $\mathrm{MC}$ & 545 & & & $3.5 \times 10^{4}$ & 104 \\
\hline Chlorpromazine & & Eosine & $\mathrm{Pd}(\mathrm{II})$ & $3.8-4.5(4.3)$ & $\mathrm{MC}$ & 545 & & & $5.7 \times 10^{4}$ & 104 \\
\hline Albumin & & PR & $\mathrm{Mo}(\mathrm{VI})$ & $1.5-5.0(2.5)$ & Gum & 600 & $0-$ & -400.0 & - & 68 \\
\hline & & PV & Mo (VI) & $2.5-3.8(3.0)$ & PVA & 680 & 0 & -300.0 & - & 75 \\
\hline & & T. Cl. Gall & $\mathrm{Mo}(\mathrm{VI})$ & $2.2-3.5(2.8)$ & PVA Triton X & 640 & 0 & -150.0 & - & 120 \\
\hline & & Sul. Phfl & $\mathrm{Ti}(\mathrm{IV})$ & $1.7-2.7(2.3)$ & Trit X405 PVA & 585 & 0 & -300.0 & & 135 \\
\hline & & 5-Br. PAPS & $\mathrm{Co}(\mathrm{II})$ & $1.5-2.0(2.0)$ & PVP & 636 & 0 & -70 & - & 151 \\
\hline & & PV & $\mathrm{Sn}(\mathrm{IV})$ & $1.4-2.1(1.7)$ & $\begin{array}{l}\text { Arabic Triton } \\
\mathrm{MF}\end{array}$ & 645 & $\begin{array}{ll}0 & - \\
0 & -\end{array}$ & $\begin{array}{l}-200 \\
-\quad 60\end{array}$ & & 155 \\
\hline & & Sul. Phfl & $\mathrm{U}(\mathrm{VI})$ & $3.2-4.2(3.8)$ & Triton N-101 & 555 & 20.0 & -500.0 & - & 124 \\
\hline Adenine & & Eosine & $\operatorname{Ag}(\mathrm{I})$ & $4.8-5.4(5.0)$ & PVP & 560 & 1.0 & $-\quad 10.0$ & $1.1 \times 10^{5}$ & 74 \\
\hline Protein & & CRB & $\mathrm{Be}(\mathrm{II})$ & $4.2-4.9(4.5)$ & Trit X405 EDTA & 625 & $0-$ & -150.0 & - & 138 \\
\hline & & Sul. Phfl & $\operatorname{Ti}(\mathrm{IV})$ & $1.7-2.7(2.2)$ & PVP Triton X101 & 590 & 5 & -200 & & 159 \\
\hline Basic-protein & & T. Cl. QnPh & $\mathrm{Mn}(\mathrm{II})$ & $9.2-9.8(9.6)$ & PVP & 590 & 0 & -200.0 & - & 143 \\
\hline ATP & & $\mathrm{QnPh}$ & $\mathrm{Fe}(\mathrm{III})$ & $9.0-9.8(9.4)$ & HPC PVP & 630 & $0-$ & $-\quad 4.0$ & $1.1 \times 10^{6}$ & 85 \\
\hline Spermine & & QnPh & $\mathrm{Cu}(\mathrm{II})$ & $4.5-4.8(4.6)$ & PVA & 585 & $0.5-$ & 3.5 & $7.0 \times 10^{5}$ & 71 \\
\hline Spermidine & & QnPh & $\mathrm{Cu}(\mathrm{II})$ & $4.5-4.8(4.6)$ & PVA & 585 & $0.7-$ & $-\quad 5.0$ & $3.0 \times 10^{5}$ & 71 \\
\hline Lysozyme & & Sul. Phfl & $\mathrm{Ti}(\mathrm{IV})$ & $(2.4)$ & PVP Triton N101 & 590 & $10-$ & -2000 & & 161 \\
\hline Chlorhexidine & & $\mathrm{QnPh}$ & $\mathrm{Mn}(\mathrm{II})$ & $9.0-9.8(9.3)$ & PVP & 560 & 0 & -150.0 & $5.88 \times 10^{4}$ & 126 \\
\hline Chlorpheniramine & & $\mathrm{QnPh}$ & $\mathrm{Ti}(\mathrm{IV})$ & $4.0-4.7(4.3)$ & SDS & 580 & 0 & -45.0 & $6.5 \times 10^{4}$ & 67 \\
\hline & & BPR & $\mathrm{Nb}(\mathrm{V})$ & $3.9-4.7$ & Tween 20 & 635 & $2-$ & $-\quad 32$ & & 167 \\
\hline Sulpyrine & & $\mathrm{QnPh}$ & $\mathrm{Ce}(\mathrm{IV})$ & Carbonate (7.5) & HTAC & 570 & $2.0^{-}$ & $-\quad 20.0$ & $1.2 \times 10^{5}$ & 77 \\
\hline Phenylpyrv & & Br. QnPh & $\mathrm{Al}(\mathrm{III})$ & $3.0-3.6(3.2)$ & $\mathrm{Zp}$ & 570 & $0-$ & $-\quad 20.0$ & $8.4 \times 10^{4}$ & 79 \\
\hline Norepinephyline & & Phfl & $\mathrm{Fe}(\mathrm{III})$ & $8.9-9.9(9.5)$ & Brij 35 & 630 & 0 & $-\quad 10.0$ & $1.7 \times 10^{5}$ & 93 \\
\hline Citric acid & & $\mathrm{QnPh}$ & $\mathrm{Fe}(\mathrm{III})$ & $9.1-10.0(9.8)$ & Tween & 610 & $0-$ & $\begin{array}{l}-\quad 7.0 \\
-\quad 1\end{array}$ & $3.2 \times 10^{5}$ & 98 \\
\hline & & Gall & $\mathrm{Sn}(\mathrm{IV})$ & 2.0 & HPC & 530 & $0.9-$ & $-\quad 40.0$ & $3.0 \times 10^{4}$ & 25 \\
\hline Tartaric acid & & $\mathrm{No}_{2}$. PAPS & $\mathrm{Nb}$ & $3.7-4.3(4.0)$ & HTAC & 612 & $0-$ & -23.0 & $1.45 \times 10^{5}$ & 165 \\
\hline Nalidixic acid & & QnPh & $\mathrm{Fe}(\mathrm{III})$ & $7.8-8.6(8.2)$ & SDBS & 610 & $0-$ & $-\quad 20.0$ & $1.3 \times 10^{5}$ & 97 \\
\hline Piromidic acid & & QnPh & $\mathrm{Fe}(\mathrm{III})$ & $7.8-8.6(8.2)$ & SDBS & 610 & $0-$ & $-\quad 20.0$ & $1.8 \times 10^{5}$ & 97 \\
\hline Phenothiazine & & CRB & $\mathrm{Be}(\mathrm{II})$ & $4.2-4.7(4.5)$ & EDTA & 620 & $0-$ & $-1.5 \times 10^{-5} \mathrm{M}$ & $7.1 \times 10^{4}$ & 144 \\
\hline Glycyrrhizinic & & Sul. Phfl & $\mathrm{Fe}(\mathrm{III})$ & $7.2-7.8(7.6)$ & Tween 40 & 625 & $0.1-$ & -12 & $8.3 \times 10^{4}$ & 156 \\
\hline Benzoperoxide & & TMPD & $\mathrm{Ce}(\mathrm{IV})$ & $4.9-5.8(5.0)$ & & 612 & 0 & -6 & $4.7 \times 10^{5}$ & 160 \\
\hline EDTA & & COOH. Phfl & $\mathrm{Ti}(\mathrm{IV})$ & $5.2-5.9(5.4)$ & Trit-N101 $\mathrm{H}_{2} \mathrm{O}_{2}$ & 615 & $10^{-6}$ & $5-6.0 \times 10^{-6} \mathrm{M}$ & & 163 \\
\hline HPC & & $\mathrm{QnPh}$ & $\mathrm{Mn}(\mathrm{II})$ & $8.8-9.6(9.3)$ & PVP & 575 & $10.0^{-}$ & -120.0 & $3.8 \times 10^{4}$ & 81 \\
\hline $\mathrm{HPC}$ & $*$ & T. Cl. Fl. $\mathrm{Hg}_{4}$ & & $6.7-7.0(6.95)$ & PVP & $\begin{array}{c}555 \\
(365)\end{array}$ & $0-$ & $-\quad 1.0$ & & 34 \\
\hline & & Cl. Gall. $\mathrm{CH}_{3}$ & & $4.3-5.4(4.6)$ & PVA & 600 & $5.0^{-}$ & $-\quad 20.0$ & $1.1 \times 10^{4}$ & 43 \\
\hline Oxine & $*$ & T. Cl. Fl. $\mathrm{Hg}_{4}$ & & $6.4-7.0(6.8)$ & PVP & $\begin{array}{c}550 \\
(365)\end{array}$ & $0-$ & $-\quad 20.0$ & & 47 \\
\hline Benzo peroxide & & NENA & & $4.5-5.5(5.0)$ & & 533 & $0-$ & -200.0 & $8.5 \times 10^{3}$ & 150 \\
\hline Glucuron acid & $*$ & NBNA & & $\mathrm{CH}_{3} \mathrm{COOH}$ & & $\begin{array}{c}508 \\
(468)\end{array}$ & $0-$ & $-\quad 50.0$ & & 145 \\
\hline Chloramine & & Gall & $\mathrm{Mo}(\mathrm{VI})$ & $1.7-2.5(1.7)$ & HTAC & 620 & $0-$ & - 90.0 & $1.1 \times 10^{4}$ & 110 \\
\hline
\end{tabular}

\footnotetext{
* fluorophotometry.
} 
との共同研究成果であり，襄心より謝意を表します．

\section{REFERENCES}

1) Ohno T., Mori I., Gifuyakkadaigaku Kiyo, 10, 60-67 (1960).

2) Ohno T., Mori I., Mori M., Mori Y,, Gifuyakkadaigaku Kiyo, 12, 40-46 (1962).

3) Ohno T., Mori I., Yakugaku Zasshi, 84, 11341137 (1964).

4) Mori I., Yakugaku Zasshi, 85, 101-104 (1965).

5) Mori I., Yakugaku Zasshi, 85, 481-485 (1965).

6) Mori I., Yakugaku Zasshi, 85, 561-564 (1965).

7) Mori I., Yakugaku Zasshi, 85, 486-495 (1965).

8) Mori I., Yakugaku Zasshi, 85, 679-685 (1965).

9) Mori I., Yakugaku Zasshi, 85, 686-692 (1965) .

10) Mori I., Yakugaku Zasshi, 86, 140-148 (1966).

11) Mori I., Yakugaku Zasshi, 86, 173-176 (1966).

12) Ohno T., Mori I., Gifuyakkadaigaku Kiyo, 16, 71-77 (1966).

13) Ohno T., Mori I., Gifuyakkadaigaku Kiyo, 17, 82-88 (1967).

14) Enoki T., Mori I., Yakugaku Kenkyu, 39, 1620 (1968).

15) Mori I., Yakugaku Zasshi, 89, 475-481 (1969).

16) Enoki T., Mori I., Izumi Y., Bunseki Kagaku, 18, 963-967 (1969).

17) Mori I., Yakugaku Zasshi, 89, 1488-1491 (1969).

18) Mori I., Enoki T., Yakugaku Zasshi, 90, 494497 (1970).

19) Mori I., Yakugaku Zasshi, 90, 241-243 (1970).

20) Mori I., Bunseki Kagaku, 19, 455-458 (1970).

21) Mori I., Yakugaku Zasshi, 90, 778-781 (1970).

22) Mori I., Yakugaku Zasshi, 90, 908-912 (1970).

23) Mori I., Bunseki Kagaku, 20, 282-287 (1971).

24) Mori I., Bunseki Kagaku, 20, 1007-1010
(1971)

25) Mori I., Yakugaku Zasshi, 91, 1387-1391 (1971).

26) Enoki T., Mori I., Yamazaki M., Inoue M., Bunseki Kagaku, 21, 31-36 (1972).

27) Mori I., Yakugaku Zasshi, 92, 264-269 (1972).

28) Yamazaki M., Mori I., Enoki T., Bunseki Kagaku, 21, 897-901 (1972).

29) Yamazaki M., Mori I., Enoki T., Bunseki Kagaku, 22, 112-114 (1973).

30) Mori I., Bunseki Kagaku, 22, 114-116 (1973).

31) Mori I., Enoki T., Mano T., Bunseki Kagaku, 22, 1202-1209 (1973).

32) Mori I., Yamamoto S., Enoki T., Bunseki Kagaku, 22, 1061-1064 (1973) .

33) Mori I., Bunseki Kagaku, 23, 291-293 (1974).

34) Mori I., Bunseki Kagaku, 23, 610-615 (1974).

35) Mori I., Yakugaku Zasshi, 95, 123-127 (1975)

36) Mori I., Fujita Y., Enoki T., Bunseki Kagaku, 24, 253-256 (1975).

37) Mori I., Fujita Y., Ida M., Enoki T., Bunseki Kagaku, 25, 239-242 (1976).

38) Mori I., Fujita Y., Enoki T., Bunseki Kagaku, 25, 388-392 (1976).

39) Mori I., Fujita Y., Nakamura N., Enoki T., Bunseki Kagaku, 26, 344-346 (1977).

40) Mori I., Fujita Y., Enoki T., Bunseki Kagaku, 26, 480-483 (1977).

41) Mori I., Fujita Y., Kamata Y., Enoki T., Bunseki Kagaku, 27, 259-263 (1978).

42) Mori I., Fujita Y., Enoki T., Yakugaku Zasshi, 98, 1145-1151 (1978).

43) Mori I., Fujita Y., Enoki T., Bunseki Kagaku, 28, 330-333 (1979).

44) Mori I., Fujita Y., Enoki T., Bunseki Kagaku, 28, 434-437 (1979).

45) Mori I., Fujita Y., Enoki T., Bunseki Kagaku, 28, 685-690 (1979).

46) Mori I., Fujita Y., Enoki T., Bunseki Kagaku, 28, 707-710 (1979).

47) Mori I., Fujita Y., Gotou E., Furuya S., Enoki T., Bunseki Kagaku, 29, 145-148 (1980).

48) Mori I., Fujita Y., Saito K., Enoki T., Bunseki Kagaku, 29, 413-416 (1980).

49) Mori I., Fujita Y., Kamata Y., Meyama M., Enoki T., Bunseki Kagaku, 29, 638-640 
(1980) .

50) Mori I., Fujita Y., Sakaguchi K., Tsuji H., Enoki T., Bunseki Kagaku, 29, 723-726 (1980) .

51) Mori I., Fujita Y., Sakaguchi K., Bunseki Kagaku, 30, 261-264 (1981).

52) Mori I., Fujita Y., Kawabe H., Sakaguchi K., Tsubone T., Bunseki Kagaku, 30, 679-682 (1981) .

53) Mori I., Fujita Y., Sakaguchi K., Bunseki Kagaku, 31, E77-E83 (1982).

54) Mori I., Yujita Y., Sakaguchi K., Bunseki Kagaku, 31, E193-E198 (1982).

55) Mori I., Fujita Y., Sakaguchi K., Bunseki Kagaku, 31, 99-102 (1982).

56) Mori I., Fujita Y., Enoki T., Bunseki Kagaku, 31, E239-E242 (1982).

57) Mori I., Fujita Y., Kitano S., Bunseki Kagaku, 31, E305-E310 (1982).

58) Mori I., Fujita Y., Sakaguchi K., Chem. Pharm. Bull., 31, 2599-2603 (1982).

59) Mori I., Fujita Y., Sakaguchi K., Kitano S., Bunseki Kagaku, 31, 475-478 (1982).

60) Mori I., Fujita Y., Sakaguchi K., Bull. Chem. Soc. Jpn., 55, 3649-3650 (1982).

61) Mori I., Fujita Y., Kitano S., Bunseki Kagaku, 32, E1-E7 (1983).

62) Fujita Y.. Mori I., Kitano S., Bunseki Kagaku, 32, E199-E205 (1983).

63) Fujita Y., Mori I., Kitano S., Chem. Pharm. Bull., 31, 1389-1391 (1983).

64) Fujita Y., Mori I., Kitano S., Chem. Pharm. Bull., 31, 1289-1295 (1983).

65) Fujita Y., Mori I., Kitano S., Bull. Chem. Soc. Jpn., 56, 2167-2168 (1983) .

66) Fujita Y., Mori I., Kitano S., Chem. Pharm. Bull., 31, 4016-4021 (1983).

67) Fujita Y., Mori I., Kitano S., Bunseki Kagaku, 32, E327-E333 (1983) .

68) Fujita Y., Mori I., Kitano S., Bunseki Kagaku, 32, E379-E385 (1983).

69) Fujita Y., Mori I., Kitano S., Kamata Y., Bunseki Kagaku, 32, E375-E378 (1983).

70) Yamazaki M., Mori I., Fujita Y., Kitano S., Kamata Y., Bunseki Kagaku, 33, 170-172 (1984) .

71) Fujita Y., Mori I., Kitano S., Kamata Y., Bunseki Kagaku, 33, E103-E106 (1984).

72) Fujita Y., Mori I., Kitano S., Chem. Pharm.
Bull., 32, 1214-1218 (1984).

73) Kitano S., Mori I., Fujita Y., Kamata Y., Bunseki Kagaku, 34, E163-E166 (1984).

74) Fujita Y., Mori I., Kitano S., Kawabe H., Kamata Y., Bull. Chem. Soc. Jpn., 57, 18281832 (1984).

75) Fujita Y., Mori I., Kitano S., Chem. Pharm. Bull., 32, 4161-4164 (1984).

76) Fujita Y., Mori I., Kitano S., Bunseki Kagaku, 33, E195-E198 (1984).

77) Fujita Y., Mori I., Kitano S., Bunseki Kagaku, 33, E383-E388 (1984).

78) Fujita Y., Mori I., Kitano S., Bunseki Kagaku, 33, E445-E448 (1984).

79) Fujita Y., Mori I., Kitano S., Koshiyama Y., Chem. Pharm. Bull., 33, 242-248 (1985).

80) Fujita Y., Mori I., Kitano S., Kawabe H., Koshiyama Y., Bull. Chem. Soc. Jpn., 58, 815 -820 (1985).

81) Fujita Y., Mori I., Kitano S., Anal. Sci., 1, 175-179 (1985).

82) Mori I., Fujita Y., Kawabe H., Fujita K., Bunseki Kagaku, 34, 648-651 (1985) .

83) Mori I., Fujita Y., Fujita K., Kitano S., Kawabe H., Koshiyama Y., Tanaka T., Miyawaki S., Nagao K., Nagai K., Chem. Pharm. Bull., 33, 4629-4632 (1985).

84) Mori I., Fujita Y., Kawabe H., Fujita K., Koshiyama Y., Tanaka T., Kamata Y., Anal. Sci., 1, 429-433 (1985).

85) Fujita Y., Mori I., Fujita K., Kitano S., Tanaka T., Chem. Pharm. Bull., 35, 5385-5392 (1985).

86) Mori I., Fujita Y., Kawabe H., Fujita K., Chem. Pharm. Bull., 34, 902-905 (1986).

87) Mori I., Fujita Y., Fujita K., Kitano S., Kotake T., Bunseki Kagaku, 35, 136-139 (1986) .

88) Mori I., Fujita Y., Fujita K., Kawabe H., Koshiyama Y., Tanaka T., Furukawa A., Nakamura T., Bunseki Kagaku, 35, 408-410 (1986) .

89) Mori I., Fujita Y., Fujita K., Kitano S., Ogawa I., Kawabe H., Koshiyama Y., Bull. Chem. Soc. Jpn., 59, 955-957 (1986) .

90) Mori I., Fujita Y., Fujita K., Koshiyama Y., Kawabe H., Tanaka T., Munakata R., Bull. Chem. Soc. Jpn., 59, 958-960 (1986) .

91) Mori I., Fujita Y., Fujita K., Usami A., 
Kawabe H., Tanaka T., Bull. Chem. Soc. Jpn., 59, 1623-1625 (1986).

92) Mori I., Fujita Y., Fujita K., Koshiyama Y., Tanaka T., Bull. Chem. Soc. Jpn., 59, 39973999 (1986).

93) Fujita Y., Mori I., Fujita Y., Tanaka T., Koshiyama Y., Kawabe H., Chem. Pharm. Bull., 34, 2236-2238 (1986).

94) Fujita Y., Mori I., Kitano S., Kawabe H., Koshiyama Y., Bull. Chem. Soc. Jpn., 59, 2585-2588 (1986).

95) Mori I., Fujita Y., Kawabe H., Fujita K., Tanaka T., Kishimoto A., Analyst, 111, 14091412 (1986).

96) Mori I., Fujita Y., Fujita K., Tanaka T., Kawabe H., Koshiyama Y., Chem. Pharm. Bull., 34, 4836-4849 (1986).

97) Fujita Y., Mori I., Fujita K., Tanaka T., Chem. Pharm. Bull., 35, 865-868 (1985).

98) Fujita Y., Mori I., Fujita K., Tanaka T., Eisei Kagaku, 33, 56-61 (1987).

99) Mori I., Fujita Y., Fujita K., Tanaka T., Yano Y., Asada M., Bull. Chem. Soc. Jpn., 60, 3077 -3079 (1987).

100) Mori I., Fujita Y., Fujita K., Tanaka T., Nakahashi Y., Yoshii A., Anal. Lett., 20, 747760 (1987).

101) Fujita Y., Mori I., Fujita K., Nakahashi Y., Nakanishi T., Yakugaku Zasshi, 107, 640-643 (1987).

102) Mori I., Fujita Y., Fujita K., Koshiyama Y., Nakahashi Y., Anal. Lett., 20, 1567-1580 (1987) .

103) Mori I., Fujita Y., Fujita K., Tanaka T., Nakahashi Y., Yano Y., Eisei Kagaku, 33, 385 -393 (1987).

104) Fujita Y., Mori I., Fujita K., Nakahashi Y., Tanaka T., Chem. Pharm. Bull., 34, 50045009 (1987).

105) Fujita Y., Mori I., Fujita K., Nakahashi Y., Chem. Pharm. Bull., 36, 254-262 (1988).

106) Mori I., Fujita Y., Fujita K., Tanaka T., Nakahashi Y., Iizuka M., Anal. Lett., 21, 279 -296 (1988).

107) Mori I., Fujita Y., Fujita K., Nakahashi Y., Tanaka T., Ishihara S., Fresenius Z. Anal. Chem., 330, 619-623 (1988).

108) Mori I., Fujita Y., Fujita K., Nakahashi Y., Kishida S., Anal. Lett., 21, 563-581 (1988).
109) Mori I., Fujita Y., Fujita K., Fujita R., Nakahashi Y., Kato K., Talanta, 35, 879-883 (1988).

110) Mori I., Fujita Y., Fujita K., Kamata Y., Koshiyama Y., Nakahashi Y., Anal. Lett., 21, 1689-1704 (1988).

111) Mori I., Fujita Y., Fujita K., Nakahashi Y., Kato K., Nakamura T., Anal. Lett., 21, 23592379 (1988).

112) Mori I., Fujita Y., Fujita K., Nakahashi Y., Matsuo R., Kato K., Fresenius Z. Anal. Chem., 333, 42-45 (1989).

113) Nakanishi T., Mori I., Fujita Y., Fujita K., J. Pharmacobio-Dyn., 12, 5-17 (1989).

114) Mori I., Fujita Y., Fujita K., Nakahashi Y., Kakimi E., Kato K., Talanta., 36, 688-690 (1989).

115) Mori I., Fujita Y., Fujita K., Nakahashi Y., Tamura K., Ohji M., Fresenius Z. Anal. Chem., 334, 49-52 (1989).

116) Mori I., Fujita Y., Ikuta K., Nakahashi Y., Kato K., Fresenius Z. Anal. Chem., 334, 252255 (1989).

117) Mori I., Fujita Y., Fujita K., Kitano S., Kawabe H., Nakahashi Y., Kato K., Inamori Y., Chem. Pharm. Bull., 37, 1827-1830 (1989).

118) Mori I., Fujita Y., Nakahashi Y., Ikuta K., Kato K., Bull. Chem. Soc. Jpn., 62, 25362540 (1989).

119) Fujita Y., Mori I., Toyoda M., Nakahashi Y., Kato K., Nakamura M., Bull. Chem. Soc. Jpn., 62, 3260-3265 (1989).

120) Fujita Y., Mori I., Ikuta K., Kato K., Nakanishi Y., Chem. Pharm. Bull., 37, 24522455 (1989).

121) Mori I., Fujita Y., Ikuta K., Nakahashi Y., Kato K., Niwa N., Anal. Lett., 22, 1969-1979 (1989)

122) Mori I., Fujita Y., Toyoda M., Ikuta K., Oshima J., Kato K., Nakamura M., Anal. Lett., 22, 3097-3111 (1989).

123) Mori I., Fujita Y., Kato K., Toyoda M., Akagi M., Bull. Chem. Soc. Jpn., 63, 359-363 (1990).

124) Fujita Y., Mori I., Toyoda M., Kato K., Nakamura M., Nakanishi T., Chem. Pharm. Bull., 38, 956-959 (1990).

125) Fujita Y., Mori I., Toyoda M., Anal. Sci., 6, 
607-508 (1990).

126) Fujita Y., Mori I., Toyoda M., Anal. Sci., 6, 807-811 (1990).

127) Mori I., Fujita Y., Toyoda M., Kato K., Akagi M., Anal. Lett., 23, 2107-2122 (1990).

128) Mori I., Fujita Y., Toyoda M., Obana A., Nakamura M., Oka S., Anal. Lett., 23, 23032314 (1990).

129) Mori I., Fujita Y., Toyoda M., Kato K., Fujita K., Okazaki Y., Talanta, 38, 343-345 (1991).

130) Fujita Y., Mori I., Toyoda M., Anal. Sci., 7, 327-328 (1991)

131) Mori I., Fujita Y., Toyoda M., Maekubo S., Bull. Chem. Soc. Jpn., 64, 1689-1691 (1991).

132) Mori I., Fujita Y., Toyoda M., Kato K., Yoshida N., Akagi M., Talanta, 38, 683-686 (1991).

133) Mori I., Fujita Y., Ikuta K., Toyoda M., Fukuda C., Kato K., Anal. Lett., 24, 871-885 (1991).

134) Mori I., Fujita Y., Toyoda M., Kashiwagi M., Fresenius Z. Anal. Chem., 340, 57-59 (1991).

135) Fujita Y., Mori I., Toyoda M., Anal. Sci., 7, 771-774 (1991).

136) Mori I., Fujita Y., Toyoda M., Kubo S., Fresenius J. Anal. Chem., 342, 80-82 (1992) .

137) Mori I., Fujita Y,. Toyoda M., Hasegawa Y., Talanta, 39, 535-539 (1992).

138) Fujita Y., Mori I., Toyoda M., Anal. Sci., 8, 313-316 (1992).

139) Mori I., Fujita Y., Toyoda M., Kimura S., Anal. Lett., 25, 1345-1354 (1992).

140) Mori I., Fujita Y., Toyoda M., Hamada M., Akagi M., Fresenius J. Anal. Chem., 343, 902 -904 (1992).

141) Mori I., Fujita Y., Toyoda M., Takeuchi Y., Fresenius J. Anal. Chem., 344, 292-294 (1992).

142) Mori I., Fujita Y., Toyoda M., Tanaka K., Anal. Lett., 25, 2377-2388 (1992).

143) Fujita Y., Mori I., Toyoda M., Anal. Sci., 8, 693-694 (1992).

144) Fujita Y., Mori I., Toyoda M., Taguchi K., Bunseki Kagaku, 42, T1-T5 (1993).

145) Mori I., Fujimoto T., Matsuo T., Nakamura M., Fujita Y., Anal. Lett., 26, 1181-1193 (1993).
146) Fujita Y., Mori I., Toyoda M., Anal. Sci., 9, 829-834 (1993).

147) Mori I., Matsuo T., Fujita Y., Toyoda M., Ichitani K., Inoue N., Fresenius J. Anal. Chem., 348, 346-349 (1994).

148) Mori I., Toyoda M., Fujita Y., Matsuo T., Taguchi K., Talanta, 41, 251-254 (1994).

149) Fujita Y., Mori I., Toyoda M., Matsuo T., Anal. Sci., 10, 827-830 (1994).

150) Mori I., Fujimoto T., Fujita Y., Matsuo T., Talanta, 42, 77-81 (1995).

151) Mori I., Taguchi K., Fujita Y., Matsuo T., Anal. Lett., 28, 225-237 (1995).

152) Mori I., Matsuo T., Toyoda M., Fujita Y., Matoba C., Akagiri K., Anal. Lett., 28, 649662 (1995).

153) Mori I., Taguchi K., Fujita Y., Matsuo T., Anal. Lett., 28, 1261-1274 (1995) .

154) Mori I., Taguchi K., Fujita Y., Matsuo T., Fresenius J. Anal. Chem., 353, 174-175 (1995).

155) Fujita Y., Mori I., Matsuo T., Bunseki Kagaku, 44, 733-738 (1995).

156) Fujita Y., Mori I., Matsuo T., Anal. Sci., 12, 115-117 (1996).

157) Mori I., Yabuki T., Fujita Y., Matsuo T., Anal. Lett., 29, 833-842 (1996).

158) Mori I., Tominaga H., Fujita Y., Matsuo T., Anal. Lett., 30, 953-961 (1997) .

159) Fujita Y., Mori I., Matsuo T., Anal. Sci., 13, 513-516 (1997).

160) Mori I., Tominaga H., Fujita Y., Matsuo T., Anal. Lett., 30, 2433-2439 (1997).

161) Naitou M., Mori I., Matsuo T., Fujita Y., Bunseki Kagaku, 46, 1003-1007 (1997) .

162) Mori I., Takasaki K., Fujita Y., Matsuo T., Talanta, 47, 631-637 (1998).

163) Fujita Y., Mori I., Matsuo T., Anal. Sci., 14, 1157-1159 (1998).

164) Mori I., Kawakatsu T., Fujita Y., Matsuo T., Anal. Lett., 32, 613-622 (1999).

165) Mori I., Kawakatsu T., Fujita Y., Matsuo T., Talanta, 48, 1039-1044 (1999).

166) Fujita Y., Mori I., Matsuo T., Anal. Sci., 15, 1009-1012 (1999).

167) Nakagawa Y., Mori I., Matsuo T., Shigemura Y., Fujita Y., Bunseki Kagaku, 48, 935-938 (1999). 